Gezgin, D. M., Hamutoğlu, N. B., Sezen-Gültekin, G. \& Yıldırım, S. (2019). Preservice Teachers’ Metaphorical Perceptions on Smartphone, No Mobile Phone Phobia (Nomophobia) and Fear of Missing Out (FoMO). Bartın University Journal of Faculty of Education, 8(2), 733-783.

Bartın University Journal of Faculty of Education, 8(2), 733-783

Bartın Üniversitesi Eğitim Fakültesi Dergisi, 8(2), 733-783

buefad.bartin.edu.tr

\title{
Preservice Teachers' Metaphorical Perceptions on Smartphone, No Mobile Phone Phobia (Nomophobia) and Fear of Missing Out (FoMO)
}

\author{
Deniz Mertkan GEZGIN**a , Nazire Burçin HAMUTOĞLU ${ }^{\mathrm{b}}$, Gözde SEZEN-GÜLTEKİNc, \\ Soner YILDIRIM ${ }^{\mathrm{d}}$
}

\begin{tabular}{|c|c|}
\hline \multicolumn{2}{|c|}{ Article Info } \\
\hline \multicolumn{2}{|c|}{ DOI: 10.14686/buefad.516540 } \\
\hline \multicolumn{2}{|c|}{ Article History: } \\
\hline $\begin{array}{l}\text { Received: } \\
\text { Accepted: } \\
\text { Published: }\end{array}$ & $\begin{array}{l}23.01 .2019 \\
06.06 .2019 \\
30.06 .2019\end{array}$ \\
\hline \multicolumn{2}{|l|}{ Keywords: } \\
\hline \multicolumn{2}{|c|}{$\begin{array}{l}\text { Nomophobia, } \\
\text { FoMO, } \\
\text { Metaphor, } \\
\text { Preservice teachers }\end{array}$} \\
\hline
\end{tabular}

\begin{abstract}
The togetherness of smartphones and social media has emerged two negative phenomena called Nomophobia and FoMO. Nomophobia, the fear of no mobile phone, and FoMO, the fear of missing out developments on social media, present a risk especially for university students. University students now have longer durations of social media and smartphone usage due to Nomophobia and FoMO. With this increase in usage, university students are more likely to be predisposed to Nomophobia and FoMO, and therefore, have problems leading to fear, anxiety and stress. This study aimed to identify pre-service teachers' metaphorical perceptions of smartphone, Nomophobia and FoMO. In the literature, studies on Nomophobia and FoMO have been conducted as quantitative research. This study was designed with mixed method which includes at least one quantitative and one qualitative method. The findings of the study differed by smartphone usage duration of the pre-service teachers and their scores of the Nomophobia Questionnaire and the FoMO scale. According to the findings, the participants frequently used the metaphors of "friend, organ, eating, need, lover" for smartphone, "being lonely, nothingness" for Nomophobia and "failing to be up to date, necessity" for FoMO
\end{abstract}

\section{Öğretmen Adaylarının Akıllı Telefon, Mobil Telefonsuz Kalma Korkusu (Nomofobi) Ve Gelişmeleri Kaçırma Korkusuna (Fomo) İlişkin Algılarının Metafor Kullanılarak Belirlenmesi}

\begin{tabular}{l} 
Makale Bilgisi \\
\hline DOI: $10.14686 /$ buefad.516540 \\
\hline Makale Geçmişi: \\
Geliş: $\quad 23.01 .2019$ \\
Kabul: $\quad 06.06 .2019$ \\
Yayın: $\quad 30.06 .2019$ \\
\hline Anahtar Kelimeler: \\
Nomofobi, \\
FoMO, \\
Metafor, \\
Öğretmen Adayları. \\
\hline Makale Türü: Araştırma makalesi
\end{tabular}

\section{Öz}

Akıllı telefonlar ve sosyal medyanın birlikteliği, Nomofobi ve FoMO olarak adlandırılan iki olumsuz durumu ortaya çıkarmıştır. Bunlardan ilki Nomofobi, mobil telefondan yoksun olma korkusu ile FoMO, sosyal medyada gelişmeleri kaçırma korkusu olarak özellikle üniversite öğrencileri üzerinde risk teşkil etmektedir. Nomofobi ve FoMO yüzünden üniversite öğrencilerinin sosyal medya ve akıll telefon kullanım süreleri artmıştır. Bu kullanım süresinin artması sonucunda, üniversite öğrencileri daha Nomofobi ve FoMO yatkın olmakta ve bu yüzünden korku, kaygı ve strese kadar yol açan sorunlar yașamaktadırlar. Bu çalıșmanın amacı da, öğretmen adaylarının akıllı telefon, Nomofobi, FoMO ile ilgili metaforik algılarını tespit etmektir. Alanyazında, Nomofobi ve FoMO ile ilgili çalışmalar incelendiğinde çalışmaların nicel araştırmalar boyutunda olduğu görülmektedir. Bu çalışma ise en az bir nicel ve bir nitel yöntem içeren karma yöntem ile desenlenmiștir. Araştırmanın bulguları, öğretmen adaylarının akıllı telefon kullanım süresine, Nomofobi ve FoMO ölçeğinden aldıkları puanlara göre farklılık göstermektedir.

*Corresponding Author: mertkan@trakya.edu.tr

a Assoc. Prof. Dr., Trakya University, Faculty of Education, Department of Computer \& Instructional Technology, Edirne, Turkey, https://orcid.org/0000-00034688-043X

bDr., Kırșehir Ahi Evran University, Faculty of Education, Department of Computer \& Instructional Technology, Kırșehir, Turkey, https://orcid.org/0000-00030941-9070

'Ress. Assist., Sakarya Üniversitesi, Faculty of Education, Department of Educational Sciences, Educational Administration and Supervision Program, Sakarya, Turkey, https://orcid.org/0000-0002-2179-4466

dProf. Dr., Middle East Technical University, Faculty of Education, Department of Computer \& Instructional Technology, Ankara, Turkey,

https://orcid.org/0000-0002-3167-2112 


\section{Introduction}

Mobile phones have become part of individuals' lives, in other words, another of their limbs. Smartphones come to mind when we say mobile phones now. With the transition of almost all applications to mobile applications (Alfawareh and Jusoh, 2014), smartphones are intensively used by young people. Youngsters, also known as generation $\mathrm{Y}$ and $\mathrm{Z}$, use particularly the social media applications via their smartphones for purposes such as communication, recreation, entertainment, catching up with the news, educational research, etc. Smartphones may also bring about negative issues among young people such as addiction due to excessive and problematic use of social media. As it is, the younger generation can face situations that will indirectly have a negative impact on quality of life such as decreased academic achievement (Erdem, Kalkın, Türen, and Deniz, 2016; Hamutoğlu, Gezgin, Samur, and Y1ldırım, 2018; Hawi and Samaha, 2016; Samaha and Hawi, 2016), decreased concentration on the course (Alt, 2015), increased loneliness (Casey, 2012; Gezgin, Hamutoglu, Sezen-Gültekin, and Ayas, 2018; Park, 2005), sleep problems (Demirci, Akgönül, and Akpınar, 2015; Gezgin, 2018; Hughes and Burke, 2018; Lemola, Perkinson-Gloor, Brand, Dewald-Kaufmann, and Grob, 2015), etc.

Symptoms of two addiction types- Nomophobia (No Mobile Phone Phobia) which refers to nonavailability of a mobile phone (King, Valença, Silva, Baczynski, Carvalho, and Nardi, 2014) and FoMO (Fear of Missing Out) (Przybylski, Murayama, and DeHaan, 2013) which is described as the fear of missing out the developments - are mentioned as the causes of these negativities in this modern era that can be also called "age of technology". Regarding the case of Nomophobia, young people cannot stay away from their smartphones and can panic, therefore having a sense of anxiety and fear when their smartphones are out of range and/or out of battery (Gezgin and Ak1ll, 2016). This can cause them to have the same fear and anxiety in future although they have their smartphones with them. Hence, behavioral patterns of nomophobic individuals include checking the smartphone frequently, not turning off the smartphone at night, going to bed with the smartphone at night and having a power bank in case any smartphone is out of battery (Ak1llı and Gezgin, 2016) It has been found that FoMO triggers problematic social media use by young people (Franchina, Vanden Abeele, van Rooij, Lo Coco, and De Marez, 2018; Przybylski et al., 2013; Vanden Abeeleand and Van Rooij, 2016). Thus, young people/university students want to stay in contact with their families and friends who are away and have the urge to use smartphone applications continuously not to miss the developments in the country and the developments in the social environment which they are connected to. This leads to the fact that young people always follow up the developments in the news source and frequently check the notifications from mobile applications, in short, their smartphones just like among nomophobic individuals.

Behavior of checking mobile applications all the time causes stress and anxiety in the individual after a while, and the younger generation tends to spend much time on social media to eliminate these anxieties. The studies investigating the prevalence of Nomophobia and FoMO among the younger generation show that the common ground of these two disorders is excessive use of smartphones, mobile internet and social media (Ak and Yıldırım, 2018; Gezgin and Çakır, 2016; Gezgin, Şahin, and Yıldırım, 2017; Gezgin, 2017; Gökler, Aydın, Ünal, and Metintaş, 2016). It is observed in the literature in regard to the studies addressing the concepts of Nomophobia and FoMO that quantitative methods are mostly used and there are almost no qualitative studies. Qualitative research method was used in this study to fill this gap in the literature and examine how individuals' perceptions of the concepts of smartphone, Nomophobia and FoMO differ. The metaphor analysis used in the study within the scope of qualitative research is considered important as it is thought to explain the concepts of smartphone, Nomophobia and FoMO in terms of student thoughts.

It is anticipated that important results will be achieved in this research aiming to identify preservice teachers' perceptions of smartphone, Nomophobia and FoMO through their metaphors and to interpret them with quantitative findings. It is also thought that the study results will define the connection between students and their smartphones and enlightening interpretations will be derived from the definitions. Furthermore, it is regarded as important to address metaphoric opinions on Nomophobia and FoMO through quantitative approaches for coping with possible situations in the future. It is also expected that the metaphors collected in the research will shed light on the results regarding the mobile phone usage by students in educational-instructional activities. Finally, the study will possibly help attract the attention of students, teachers, administrators, parents and researchers who will conduct academic research in the future for understanding the concepts of Nomophobia and FoMO. In the light of the above mentioned, this research aimed to identify through metaphors how the preservice teachers attending in 
a state university, faculty of education perceive the concepts of mobile phone, fear of no mobile phone and fear of missing out the developments on social networking sites and to interpret the metaphors with quantitative findings and discuss them according to the literature.

\section{Literature Review}

There are more and more studies carried out on Nomophobia and FoMO in the literature. World Health Organization reports that depression will take the first place around the world with technology advancing in parallel with human life by 2020. Even though what is meant by technology was not stated in the statistical report regarding the increase of aging, it is thought to be referring to social media, Internet and smartphones. As for the studies on Nomophobia and FoMO in the literature, the majority has been carried out on teachers, university students and adolescents. In the studies carried out in the field, Dağl1, Hamutoğlu and Gezgin (2017) stated that Nomophobia levels were not significant by gender and had a negative relationship with the age variable. Dağli, Gezgin, Hamutoğlu, and Sezen-Gültekin (2017) examined participants' Nomophobia levels by several variables (mobile phone usage, mobile game play, mobile game play duration, number of daily mobile phone charging and teachers' career stages) and concluded that increased mobile game play duration and number of daily mobile phone charging increased Nomophobia levels of the teachers in the study with preschool teachers. In addition, the study findings showed no significant difference in Nomophobia levels by mobile game play and mobile game play duration whereas it was emphasized that increased skill of using all features of mobile phones increased Nomophobia levels of the teachers. It is finally reported in the study that there was a significant difference between teachers' Nomophobia levels and career stages.

It is possible to observe studies examining Nomophobia among university students by several variables (owning a smartphone, daily frequency of checking smartphone, duration of having mobile internet, daily mobile internet usage duration and mobile internet quota, gender, grade level, age, impulsiveness, achievement grade, educational level of parents) (Akıllı and Gezgin, 2016; Burucuoğlu, 2017; Durak, 2018a; Erdem et al., 2016; Gezgin, 2017; Gezgin and Çakır, 2016; Gezgin, Çakır, and Yıldırım, 2018; Gezgin, Şumuer, Arslan, and Yıldırım, 2017; Sirakaya, 2018; Yıldırım, Sumuer, Adnan, and Yildırım, 2016). Similarly, the prevalence of Nomophobia among social media users has been studied by various factors (educational level and duration of owning a mobile phone, daily number of smartphone checks, mobile internet usage duration and daily mobile internet usage duration) (Gezgin, Şahin, and Yıldırım, 2017). On young adults, Uysal, Özen, and Madenoğlu (2016) found a low but significant relationship between Nomophobia and social phobia; it was reported that the increased level of Nomophobia caused a predictable increase in social phobia. In another study carried out on individuals with extreme social phobia, smartphones and personal computers were used as an instrument to ease symptoms of social phobia. The findings showed that social phobia behaviors were observed among individuals suffering from nonavailability of a smartphone or personal computer, and individuals with disorders accompanying social phobia and obsessive-compulsive disorders were those who were affected by Nomophobia (King et al., 2014). The case study performed by King et al. (2014) on 11 individuals with social phobia and showing nomophobic symptoms concluded that the patient diagnosed with social phobia disorder was dependent on the virtual environment to communicate with people whom they were in touch with, and the case was interpreted as avoiding direct social relations with others. Similarly, the studies (Fuster, Chamarro, and Oberst, 2017; Gezgin, Hamutoğlu, Gemikonakl1, and Raman, 2017; Hayran, Anik, and Gürhan-Canlı, 2016) on FoMO, which is defined as fear of missing out the developments in social networks, state that individuals with high levels of FoMO interact with Facebook more and have low general mood, low levels of welfare and satisfaction with life (Przybylski et al., 2013). There are also studies examining the relationship between FoMO and gender, age, number of owned social media accounts, status of social media usage and daily online status (Gezgin, Hamutoğlu, Gemikonaklı, and Raman, 2017; Gökler et al., 2016; Hoşgör, Tütüncü, Hoşgör, and Tandoğan, 2017). In the study examining the prevalence of FoMO among university students by different variables, Hoşgör, Tütüncü, Hoşgör, and Tandoğan (2017) observed that the students who were inclined to have FoMO carried a charger with them all the time, checked their smartphones as soon as they woke up, went to bed with their smartphones, logged into social media actively every day, checked their smartphones at least 50 times a day, had owned a social media account for at least 7 years, had at least 4 different social media accounts and spent at least 7 hours on social media. Similar to this study, with the idea that FoMO increases social media usage, the study performed by Beyens, Frison, and Eggermont (2016) on adolescents found strong positive relationships between adolescents' need for popularity and belonging and fear of getting lost and perceived stress due to Facebook usage, not being popular among their friends in Facebook and the sense of not belonging to Facebook. It has also been reported that students spend time 
with their smartphones and have decreased concentration in the course due to FoMO and excessive use of social media (Alt, 2015).

As seen in the literature, studies on the new phenomena of Nomophobia and FoMO are increasing very rapidly. However, seemingly, these studies have been carried out rather in accordance with quantitative research designs, mostly the findings obtained via variables related to Nomophobia and FoMO have been reported, and these findings have been discussed in terms of the symptoms caused by FoMO. Although the studies on the concepts of Nomophobia and FoMO bring about the idea that the literature has been sufficiently saturated, no studies on students' perceptions of these two concepts, which are very similar to each other in terms of their symptoms, have been performed in the literature yet. So, it is thought that identifying the students who have been exposed to these two negative concepts according to quantitative approaches and exploring their metaphorical perceptions of these concepts will fill the gap in the related literature. Finally, it is also possible that the interpretation of the quantitative and qualitative findings together will contribute to the literature. Accordingly, this study sought answers to the following questions:

1. What are participants' metaphorical perceptions of smartphone?

1a. Do participants' metaphorical perceptions change by their daily smartphone usage duration?

2. What are participants' metaphorical perceptions of Nomophobia?

2a. Do participants' metaphorical perceptions differ by their low or high levels of Nomophobia?

3. What are participants' metaphorical perceptions of FoMO?

3a. Do participants' metaphorical perceptions differ by their low or high levels of FoMO?

\section{Method}

This study was planned and conducted as an example of mixed method research. Mixed method research defined by Greene, Caracelli, and Graham (1989) as research designs involving at least one quantitative and one qualitative method (in Metin, 2015) is utilized by the researcher combining qualitative and quantitative methods, approaches and concepts in a study or consecutive studies (Creswell, 2003) and described as studies that allow the research to triangulate the results obtained by quantitative and qualitative components of the study, therefore achieving confirmation, reinforcement or cross-validation in a single study (Creswell, 2013). In this respect, this study was planned and conducted using the mixed method by means of simultaneous design through combination of quantitative and qualitative research questions and simultaneous data collection.

The first part is an example of the survey model of quantitative research methods; the obtained data were presented causally-comparatively in terms of different variables. Survey models are research approaches aiming to describe a past or current situation as it was or it is (Karasar, 2009) while causal-comparative research aims to examine the causes or outcomes of current differences between groups of individuals (Fraenkel, Wallen, and Hyun, 2012). The second part identified preservice teachers' perceptions of Nomophobia and FoMO concepts using metaphors, utilized the qualitative research method and was designed with phenomenology. The phenomenology design focuses on the phenomena which we are aware of but do not have a deep and detailed insight on. Phenomena can be in the form of events, experiences, perceptions, orientations, concepts and situations in our world (Annells, 2006; Creswell, 2013; Yıldırım and Şimşek, 2011). Metaphor studies utilize a qualitative approach through which the researcher examines one or multiple situations that have been limited over time in depth by defining these situations and situation-related themes via data collection tools (observations, interviews, audio-visuals, documents, and reports) (Tavşancıl and Aslan, 2007). Individual experiences underlie phenomenology. In this design, the researcher is engaged in participant's subjective experiences and examines their perceptions and the meanings they attribute to the events. Phenomenology is a descriptive research design. In this context, it is important not to generalize but define the phenomena (Akturan and Esen, 2008). With these two approaches used in the study, it is thought that the research question was addressed in a more complementary and holistic manner and understood better. 


\section{Study Group}

This study was conducted in the spring term of 2017-2018 academic year, and a total of 111 preservice teachers studying at different programs in Faculty of Education in a state university in the Thrace region participated in. The quantitative data obtained from the participants were categorized as being low and high depending on the mean total scores of Nomophobia Questionnaire and FoMO Scale and the variable of daily smartphone usage duration, and metaphors were determined for each category. The participants were volunteered for the study, and convenience sampling method was used for sampling.

\section{Data Collection Tools}

The data were collected in the classroom setting through the answers given by the participants to the scale forms which had been distributed by the researchers face to face. Before collecting the data, the students were first informed of the research subject and the fact that the data provided by them voluntarily would be used only for the study. The scale forms were completed in about 10-12 minutes. The 10-item FoMO Scale originally developed by Przybylski et al.(2013) and adapted to Turkish language by Gökler et al. (2016) was used for collecting the quantitative data. The 20-item Nomophobia Questionnaire developed by Y1ldırım and Correia (2015) and adapted into Turkish language by Yıldırım, Sumuer, Adnan, and Yıldırım (2016) was used additionally. Finally, a structured interview form consisting of three questions that were prepared by the researchers was applied to identify the participants' metaphorical perceptions.

Nomophobia Questionnaire The Nomophobia Questionnaire achieved upon development and adaptation studies is a 20-item, 7-point Likert scale. Items of the questionnaire are scored from 1 (Strongly Disagree) to 7 (Strongly Agree). The Nomophobia Questionnaire is composed of four subscales: not being able to access information (4 items), losing connectedness (5 items), not being able to communicate (6 items), and giving up convenience (5 items). The following are exemplary items of the subscales: "I would feel uncomfortable without constant access to information through my smartphone" in not being able to access information; "Running out of battery in my smartphone would scare me" in losing connectedness; "If I did not have my smartphone with me, I would feel anxious because I could not instantly communicate with my family and/or friends" in not being able to communicate; and "I would be nervous because I would be disconnected from my online identity" in giving up convenience. The internal consistency coefficient calculated with Cronbach's Alpha is .95 for the original scale while the internal consistency coefficient was calculated to be .92 for the Turkish version of Nomophobia Questionnaire. While the reliability coefficients calculated for the original subscales of the original scale are .94, $.87, .83$, and .81 respectively, the reliability coefficients are $.90, .74, .94$, and .91 for the Turkish version.

Fear of Missing Out (FoMO) Scale The FoMO Scale consists of 10 items each scored on a 5-point Likert scale. Each item in the scale is scored from 1 to 5 points ( $1=$ not at all true, $5=$ extremely true). The scores obtained from the scale vary between 10 and 50, and the scale does not have a cutoff score. Higher scores mean "individuals are more likely to have fear of missing out." "I fear others have more rewarding experiences than me" is an exemplary item of the FoMO Scale. The reliability coefficient of the original scale calculated using Cronbach's Alpha is .95 while it is .81 for the Turkish version.

Structured Interview Form (Questions of Metaphor) The questions asked to identify participants' metaphorical perceptions were prepared by the researchers, and three different questions were asked to the participants. Accordingly, the first question is "Mobile phone is like... for me. Because..." which serves to identify their perceptions of mobile phone metaphorically. The second question is "Fear of no mobile phone is like... for me. Because..." which metaphorically helps find out about what the participants go through when their mobile phones are not with them. Finally, the question is "Fear of missing out (in regard to social media, developments, etc.) is like... for me. Because..." was asked to the participants to find out about what they go through when missing out developments on social media.

\section{Data Analysis}


The data were subjected to a content analysis, which is a qualitative research method, and interpreted using the quantitative research findings. In this regard, descriptive statistics and qualitative data analysis techniques were utilized in the data analysis. Whether the obtained data were suitable for metaphor was tested by two different experts. Accordingly, 9 answers were decided to be excluded from the study because they were not suitable for metaphor for mobile phone. Each metaphor created by the participants was encoded by the first researcher in the first place. Next, the codes with similar meanings were grouped together to form categories. For example, it is possible to understand from the preservice teacher statements "... Because...", “... Because..." and their metaphors regarding the fear of no mobile phone that the preservice teachers perceived the fear of no mobile phone as .... Therefore, these metaphors encoded by the first researcher were grouped in the category of "......" Then, the second researcher examined the coding and categories provided by the first researcher and gave a positive and negative opinion. The formula "Reliability = Agreement / (Agreement + Disagreement)" was utilized for the data reliability (Miles and Huberman, 1994), and the agreement between the researchers was found to be on an acceptable level. Furthermore, two field experts who have work in the domain of Nomophobia and FoMO were consulted for opinions and did check the validity and reliability. The validity of the study was enhanced through direct quotations using the participant opinions in the findings section.

Next, participants' scores of the Nomophobia Questionnaire and FoMO Scale were classified as being low and high by means of the data at hand. Participants' metaphorical perceptions were identified in the areas categorized in each scale to make comparisons in terms of different variables, and these two concepts which are considered interrelated were investigated comparatively and in depth. Moreover, the data obtained from the variable of daily smartphone usage duration was utilized for identifying participants' metaphorical perceptions of smartphone. Similarly, participants' metaphorical perceptions were categorized by the mean of the data presented by the variable of daily smartphone usage duration.

\section{Validity and Reliability}

A focus group interview was performed with a group similar to the study group for the clarity of the interview questions. The fact that the participants volunteered for the study and were informed that the research findings would be used only in the study serves to the reliability of the study. Observer triangulation was performed to increase external validity in the analysis of qualitative data; the obtained data were reviewed by three different experts.

\section{Findings}

The metaphorical data obtained from the participants were examined under separate headings for mobile phone, Nomophobia and FoMO within the scope of Daily Smartphone Usage Duration (DSUD). Furthermore, the metaphors generated under the headings of Mobile Phone, Nomophobia and FoMO were addressed under separate subheadings of "above and below mean". The findings achieved in regard to the metaphors are as follows:

\section{Mobile Phone Metaphors by DSUD}

\section{Findings on Mobile Phone Metaphor}

The metaphors generated for the concept of mobile phone were examined; 9 forms were excluded from the analysis as the answers of 9 participants were not suitable for the metaphor, and 102 participant opinions were evaluated. It was observed in this evaluation that some of the metaphors were repeated, and the related findings are presented in the table below: 
Table 1. Metaphors for Mobile Phone

\begin{tabular}{|c|c|c|c|}
\hline Junk food & Entertainment & Cane of a blind man & Area of conversation \\
\hline Being active & Washcloth & A bad friend & Respirator \\
\hline Journal & Magnet sticking to hand & Mega closet & Sports \\
\hline Car & Lack of electricity & Microphone & Stress ball \\
\hline Driving a car & $\begin{array}{l}\text { Medication that relieves } \\
\text { concerns }\end{array}$ & Organ $(f=4)$ & Water $(\mathrm{f}=2)$ \\
\hline Friend $(f=4)$ & Fenerbahçe & Bus & $\begin{array}{l}\text { Sneijder, the brain of the } \\
\text { team }\end{array}$ \\
\hline Love & Pigeon and eye & Playing a game & Carrot of rabbit \\
\hline Artery & News tool & Toy $(\mathrm{f}=2)$ & Toilet paper \\
\hline An integral part & Source of news & Student pen & Salt $(\mathrm{f}=2)$ \\
\hline Computer & An imaginary friend & Spider web & Sleep \\
\hline Bike & Life $(\mathrm{f}=2)$ & Belongings & Drug \\
\hline An empty material & Partner for life & Homing pigeon & Assistant $(\mathrm{f}=2)$ \\
\hline Lifeguard & Lifestyle & $\begin{array}{l}\text { Postman, an unnecessary } \\
\text { letter }\end{array}$ & Life coach \\
\hline Wallet & A part of life $(\mathrm{f}=2)$ & Time bomb & Source of life \\
\hline Bag & Indispensable for life & Soap & The sole asset and wealth \\
\hline Tea & Treasure & Serum & Eating $(f=4)$ \\
\hline Body armor & The world I live in & Vocal cord & Road \\
\hline Chocolate & Need $(f=3)$ & Lover $(\mathbf{f}=3)$ & Seatmate $(\mathrm{f}=2)$ \\
\hline $\begin{array}{l}\text { Blood flowing in } \\
\text { the vein }\end{array}$ & $\begin{array}{l}\text { Object that satisfies a } \\
\text { need }\end{array}$ & A warm house & Time machine \\
\hline Close friend & Medication & Cigarette & \multirow{2}{*}{ Total: $(f=82)$} \\
\hline World itself & Coffee & Smoking & \\
\hline
\end{tabular}

Table 1 shows that the metaphors generated for the concept of mobile phone were quite different $(\mathrm{f}=82)$. According to the data obtained from the participants, the most repeated metaphors for the concept of mobile phone were friend $(f=4)$, organ $(f=4)$, eating $(f=4)$, need $(f=3)$, lover $(f=3)$. It can be accordingly argued that mobile phone was perceived by the participants rather as a friend, a lover or need, eating, and an organ. The statements provided by the participants for their metaphors can be exemplified as follows:

P4: "Organ. Because it is not possible to do anything without it."

P74: "Need. Because I need to talk to my friends and family. That is why it is a must for me."

\section{Findings on Mobile Phone Metaphors Examined by Means}

The participants were asked about their daily smartphone usage durations, these durations were averaged $(\bar{X}=6.53)$, and the metaphors generated for the concept of mobile phone by 38 participants above mean and 64 participants below mean were examined. The findings achieved in this examination are presented in the tables below. 
Table 2. Metaphors Generated by the Participants with Mobile Phone Usage Levels above Mean

\begin{tabular}{|c|c|c|}
\hline Category & Metaphor & Example \\
\hline 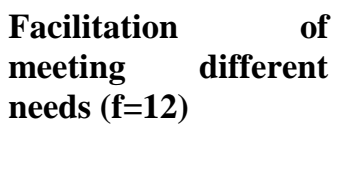 & $\begin{array}{l}\text { Love, Medication that relieves concerns, } \\
\text { Eating, Time bomb, Driving, Magnet sticking } \\
\text { to hand, Stress ball, Bag, Life coach, } \\
\text { Microphone, Road, Tea }\end{array}$ & $\begin{array}{l}\text { P86: "Microphone. Because it makes } \\
\text { it easier for me to make my voice } \\
\text { heard. }\end{array}$ \\
\hline $\begin{array}{l}\text { Addiction- } \\
\text { indispensability } \\
(\mathbf{f}=\mathbf{2 1})\end{array}$ & $\begin{array}{l}\text { Salt }(\mathbf{f}=\mathbf{2}) \text {, Organ }(\mathbf{f}=\mathbf{2}) \text {, Drug, Lack of } \\
\text { electricity, A part of life, Respirator, Object } \\
\text { that satisfies a need, Life, Sleep, Smoking, } \\
\text { Cigarette, Eating, Lover, Belongings, } \\
\text { Seatmate }\end{array}$ & $\begin{array}{l}\text { P42: "Organ. Because it is like a part } \\
\text { of mine, my foot or arm now." }\end{array}$ \\
\hline Friendship $(f=5)$ & $\begin{array}{l}\text { Friend }(\mathbf{f}=\mathbf{2}) \text {, Lifeguard, Seatmate, Close } \\
\text { friend }\end{array}$ & $\begin{array}{l}\text { P52: "Close friend. Because it has all } \\
\text { my information and my privacy. The } \\
\text { mobile phone will not betray like } \\
\text { other people will." }\end{array}$ \\
\hline
\end{tabular}

The reasons for the metaphors generated by the participants with mobile phone usage levels above mean were reviewed, and the categories created according to these reasons were given in Table 2. In this regard, metaphors for the concept of mobile phone were grouped in the categories of facilitation of meeting different needs $(f=12)$, addiction-indispensability $(f=21)$, and friendship $(f=5)$. Given these categories, the metaphors used for mobile phone were addiction, facilitation of meeting different needs and friendship respectively. In this case, it can be argued that the participants using mobile phone above mean perceived mobile phone rather as an indispensable object which causes addiction.

Table 3. Metaphors Generated by the Participants with Mobile Phone Usage Levels below Mean

Category Metaphor Example

Facilitation of Friend ( $\mathbf{f = 3}$ ), Pigeon and eye, Time machine, meeting Car, Student pen, An imaginary friend, Homing different needs pigeon, Lover, An empty material, News tool, (f=41) Spider web, The world itself, Toy, Assistant, Body armor, Need, Mega closet, Medication, Treasure, Lifestyle, Entertainment, Coffee, Lover, Area of conversation, Being active, Computer, Assistant, Sports, Source of news, Serum, Life partner, Journal, Toy, Bike, Playing a game, Washcloth, Bus, Vocal cord, Postman an unnecessary letter
P54: "Serum. Because what is happening in the world in a day, the developments are is important to me. All everyday work, communication, information takes place through it; it makes our lives easier.
Addiction- $\quad$ Need (f=2), Eating, The sole asset and wealth, indispensability Junk food, Wallet, Chocolate, Blood flowing in $(\mathbf{f}=\mathbf{2 3})$ the vein, Life, Sneijder - the brain of the team, A part of life, Cane of a blind human, Water, The world lived in, A bad friend, Artery, A warm house, Organ, An integral part, Water, Soap, Fenerbahçe, Toilet paper
P58: "Sneijder, the brain of our team. Because it is indispensable, in the middle of our lives; it actually directs us. We can say it is at the center of our lives. For example, it is as if you felt empty when your phone is not with you or out of charge. The same applies with Sneijder; they cannot do it without him. Something is missing." 
The reasons for the metaphors generated by the participants with mobile phone usage levels below mean were reviewed, and the categories created according to these reasons were given in Table 3. Metaphors for the concept of mobile phone were grouped in the categories of facilitation of meeting different needs $(f=41)$ and addiction-indispensability $(\boldsymbol{f}=\mathbf{2 1})$. It is accordingly possible to say that the participants using mobile phone below mean perceived it rather as a facilitating factor in meeting different needs (communication, following up the agenda, etc.)

\section{Findings on FoMO Metaphor}

Some of the metaphors generated for FoMO were observed to be repeated. The findings on FoMO metaphors are presented in Table 4 below.

Table 4. Metaphors for FoMO

\begin{tabular}{|c|c|c|c|}
\hline Hunger & Not understanding the joke & Change of marital status & Joke \\
\hline $\begin{array}{l}\text { Getting stuck in } \\
\text { elevator }\end{array}$ & A physiological need & Curiosity and excitement & $\begin{array}{l}\text { Living in the Stone } \\
\text { Age }\end{array}$ \\
\hline Antisociality $(f=2)$ & $\begin{array}{l}\text { Falling behind the agenda } \\
(f=4)\end{array}$ & That day was wasted & $\begin{array}{l}\text { An insignificant } \\
\text { person gets mad at } \\
\text { a big shot }\end{array}$ \\
\hline Blanket & Remaining uninformed & $\begin{array}{l}\text { Staying away from events, } \\
\text { desperation }\end{array}$ & Flying chickens \\
\hline $\begin{array}{l}\text { A box of goods kept } \\
\text { hidden from me }\end{array}$ & Prison & Dead man & Treatment \\
\hline Beşiktaş & Detaching from life $(\mathrm{f}=2)$ & Death & Train \\
\hline $\begin{array}{l}\text { Sitting at the forefront } \\
\text { in a seminar I do not } \\
\text { know anything about }\end{array}$ & Isolation from everything & A trivial event & $\begin{array}{l}\text { Not being able to } \\
\text { go to the toilet }\end{array}$ \\
\hline $\begin{array}{l}\text { Living alone in a } \\
\text { village }\end{array}$ & Nothing $(\mathrm{f}=2)$ & Dream & Salt \\
\hline Void & Hypnosis & Purity & $\begin{array}{l}\text { A life without salt } \\
\text { and sugar }\end{array}$ \\
\hline Ice skating & $\begin{array}{l}\text { Ending up on a deserted } \\
\text { island }(f=3)\end{array}$ & Being deaf & Watching TV $(\mathrm{f}=2)$ \\
\hline $\begin{array}{l}\text { Remaining ignorant, } \\
\text { uninformed }(f=3)\end{array}$ & $\begin{array}{l}\text { Breaking out of } \\
\text { communication }\end{array}$ & Becoming deaf, blind & Insomnia \\
\hline Boredom & Staying in dark $(\mathrm{f}=2)$ & Getting crippled & Sleeping \\
\hline Hurting really bad & Getting lost & An ordinary day & Drug \\
\hline
\end{tabular}




\begin{tabular}{|c|c|c|c|}
\hline Chocolate $(\mathrm{f}=2)$ & Having no one around $(\mathrm{f}=2)$ & Losing my eraser & Estrangement \\
\hline $\begin{array}{l}\text { Falling asleep in the } \\
\text { night of coup }\end{array}$ & A bad incident $(f=3)$ & Fly bite & Wound \\
\hline $\begin{array}{l}\text { Fear of being late for } \\
\text { class }\end{array}$ & Credit card & Not going to the movies & $\begin{array}{l}\text { Not feeling that I } \\
\text { live }\end{array}$ \\
\hline Being excluded $(\mathrm{f}=2)$ & Pencil & Political sciences & Food \\
\hline Dieting & Lens & Socialness & $\begin{array}{l}\text { Small stones on the } \\
\text { roadside }\end{array}$ \\
\hline $\begin{array}{l}\text { Something missing } \\
(\mathrm{f}=2)\end{array}$ & Living in a cave & Isolation & Waste of time \\
\hline $\begin{array}{l}\text { Kid whose toy is taken } \\
\text { from their hand }\end{array}$ & $\begin{array}{l}\text { Staying indifferent even if the } \\
\text { neighborhood is on fire }\end{array}$ & $\begin{array}{l}\text { Grocery that does not sell } \\
\text { water }\end{array}$ & $\begin{array}{l}\text { Falling behind the } \\
\text { times }(\mathrm{f}=2)\end{array}$ \\
\hline Staying in the old age & Mushroom & Fish out of the water & $\begin{array}{l}\text { Total: } 83 \text { different } \\
\text { metaphors }\end{array}$ \\
\hline
\end{tabular}

According Table 4, the metaphors generated for the concept of mobile phone considerably differed ( $\mathrm{f}=83$ ). The data obtained from the participants indicate that the most repeated metaphors for the concept of FoMO were falling behind the agenda $(f=4)$, remaining ignorant, uninformed $(f=3)$, ending up on a deserted island $(f=3)$, a bad incident $(f=3)$. So, it can be argued that FoMO was perceived as more of a negative situation. This is why most of the participants seemed to have the fear of missing out. The statements provided by the participants for their metaphors can be exemplified as follows:

P58: "Dieting. Because life would have no taste."

P5: "Ending up on a deserted island. Because, in either case, I feel like I cannot stay informed of my surroundings."

\section{Findings on FoMO Metaphors Examined by Means}

Findings on the FoMO metaphors generated by the participants who had scores above mean $(\bar{X}=28.93)$ in the FoMO Scale are shown in Table 5. 
Table 5. FoMO Metaphors Generated by the Participants with FoMO Levels above Mean

\begin{tabular}{|c|c|c|}
\hline Category & Metaphor & Example \\
\hline $\begin{array}{l}\text { Necessity } \\
(\mathbf{f}=15)\end{array}$ & $\begin{array}{l}\text { A physiological need, getting crippled, fear of being } \\
\text { late for class, food, something missing, hunger, } \\
\text { insomnia, wasting a day, death, life without salt and } \\
\text { sugar, credit card, detaching from life, losing my } \\
\text { eraser, dieting, fish out of water }\end{array}$ & $\begin{array}{l}\text { P1: "A physiological need. Because } \\
\text { what is going on on social media is } \\
\text { always in the back of my mind." }\end{array}$ \\
\hline $\begin{array}{l}\text { Failing to be } \\
\text { up to date } \\
(\mathbf{f}=32)\end{array}$ & $\begin{array}{l}\text { Purity, getting lost, exclusion from any } \\
\text { environment, finding nothing to do, isolation, } \\
\text { political sciences, something missing, becoming } \\
\text { deaf-blind, death, a bad incident, being deaf, living } \\
\text { in the Stone Age, detaching from life, staying away } \\
\text { from events-desperation, falling asleep in the night } \\
\text { of coup, remaining uninformed, prison, staying in } \\
\text { the old age, antisociality, inability to feel alive, a } \\
\text { dead man, ignorance }(f=3) \text {, falling behind }(f=3) \text {, } \\
\text { falling behind the times }(f=2) \text {, ending up on a } \\
\text { deserted island }(f=2)\end{array}$ & $\begin{array}{l}\text { P40: "A dead man, falling behind in } \\
\text { every event, remaining uninformed. } \\
\text { Because it causes me not to follow up } \\
\text { the people around me and not to have } \\
\text { an idea about what they have been } \\
\text { doing when I meet with them." }\end{array}$ \\
\hline $\begin{array}{l}\text { Disappointm } \\
\text { ent }(f=4)\end{array}$ & $\begin{array}{l}\text { Dream, kid whose toy is taken from their hand, } \\
\text { hypnosis, joke }\end{array}$ & $\begin{array}{l}\text { P12: "Kid whose toy is taken from } \\
\text { their hand. Because I get so bored, I } \\
\text { cannot do the things I want and have } \\
\text { fun with." }\end{array}$ \\
\hline $\begin{array}{l}\text { Loneliness } \\
(\mathbf{f}=5)\end{array}$ & $\begin{array}{l}\text { Desolation }(f=2) \text {, living alone in a village, } \\
\text { exclusion, being isolated from everything }\end{array}$ & $\begin{array}{l}\text { P7: "Desolation. Because I feel like } \\
\text { alone when I do not know about } \\
\text { anything." }\end{array}$ \\
\hline $\begin{array}{l}\text { A situation } \\
\text { that can be } \\
\text { accustomed } \\
\text { to }(f=7)\end{array}$ & $\begin{array}{l}\text { Fly bite, mushroom, a trivial event, small stones on } \\
\text { the roadside, news, not being able to watch the news } \\
\text { report, blanket, chocolate }\end{array}$ & $\begin{array}{l}\text { P54: "Blanket. Because it is okay } \\
\text { without it; you could only warm less. } \\
\text { It is like that for me, too." }\end{array}$ \\
\hline
\end{tabular}

The reasons for the metaphors generated for FoMO by the participants with FoMO levels above mean were reviewed, and the categories created according to these reasons were given in Table 5. In this respect, metaphors for the concept of FoMO were grouped in the categories of necessity $(f=15)$, failing to be up to date $(f=32)$, disappointment $(f=4)$, loneliness $(f=5)$, and a situation that can be accustomed to $(f=7)$. It can inferred from these categories that the participants with high FoMO levels perceived FoMO rather as failing to be up to date and missing the most basic needs. 
Table 6. FoMO Metaphors Generated by the Participants with FoMO Levels below Mean

\begin{tabular}{|c|c|c|}
\hline Category & Metaphor & Example \\
\hline $\begin{array}{l}\text { Necessity } \\
(\mathbf{f}=9)\end{array}$ & $\begin{array}{l}\text { Hurting really bad, chocolate, change of marital } \\
\text { status, my lenses, detail, curiosity and excitement, } \\
\text { salt, treatment, not being able to go to the toilet }\end{array}$ & $\begin{array}{l}\text { P1: "Hurting really bad. Because we } \\
\text { are at an addictive level; we cannot } \\
\text { be without it." }\end{array}$ \\
\hline $\begin{array}{l}\text { Failing to be } \\
\text { up to date } \\
(\mathbf{f}=20)\end{array}$ & $\begin{array}{l}\text { A bad incident, sleeping, hidden goods, getting } \\
\text { stuck in elevator, grocery that does not sell water, } \\
\text { having nothing to do, not understanding the joke, } \\
\text { train, breaking out of communicating, remaining } \\
\text { uninformed, boredom, a hungry human whose food } \\
\text { is taken from them, sitting at the forefront in a } \\
\text { seminar I do not know anything about, prison, } \\
\text { falling behind the agenda }(\mathrm{f}=2) \text {, staying in dark } \\
(\mathrm{f}=2) \text {, ending up on a deserted island }(\mathrm{f}=2)\end{array}$ & $\begin{array}{l}\text { P51: "Prison. Because it is important } \\
\text { for me not to miss the events." }\end{array}$ \\
\hline $\begin{array}{l}\text { Loneliness } \\
(\mathrm{f}=2)\end{array}$ & An antisocial person, alienation & $\begin{array}{l}\text { P25: "Alienation. Because you } \\
\text { disconnect from the environment." }\end{array}$ \\
\hline $\begin{array}{l}\text { A situation } \\
\text { that can be } \\
\text { accustomed } \\
\text { to }(f=16)\end{array}$ & $\begin{array}{l}\text { Wound, staying indifferent even if the } \\
\text { neighborhood is on fire, an ordinary day, drug, } \\
\text { Beşiktaş, nothingness, pencil, not going to the } \\
\text { movies, nothing, ice skating, void, waste of time, } \\
\text { being more social, an insignificant person gets mad } \\
\text { at a big shot, watching TV }(\mathrm{f}=2)\end{array}$ & $\begin{array}{l}\text { P4: "Wound. Because a wound hurts } \\
\text { at first, then if it scabs and does not } \\
\text { hurt as it used to, missing out will } \\
\text { make the same effect. A void at first, } \\
\text { but you become accustomed." }\end{array}$ \\
\hline
\end{tabular}

The reasons for the metaphors generated for FoMO by the participants with FoMO levels below mean score from the scale were reviewed, and the categories created according to these reasons were given in Table 6. In this regard, metaphors for the concept of FoMO were grouped in the categories of necessity $(f=9)$, failing to be up to date $(f=20)$, loneliness $(f=2)$, and a situation that can be accustomed to $(f=16)$. It can be argued according to these categories that the participants with low FoMO levels perceived FoMO rather as failing to be up to date and a situation that can be accustomed to.

\section{Findings on Nomophobia Metaphors}

It seems that some of the Nomophobia metaphors were repeated. The findings on these metaphors are presented in Table 7 below. 
Table 7. Metaphors for Nomophobia

\begin{tabular}{|c|c|c|c|}
\hline Getting hungry & Entering the class & Zucchini & $\begin{array}{l}\text { Not having my watch on } \\
\text { my wrist }\end{array}$ \\
\hline $\begin{array}{l}\text { Child of divorced } \\
\text { parents }\end{array}$ & Being on a knife edge & $\begin{array}{l}\text { Staying in an indoor } \\
\text { area }(\mathrm{f}=3)\end{array}$ & Silence \\
\hline $\begin{array}{l}\text { Not being able to take } \\
\text { alcohol }\end{array}$ & Freefalling in a bottomless pit & Turtle & Being late for the exam \\
\hline Blasting my car tire & Becoming a widow & Black hole & $\begin{array}{l}\text { Having no eraser during } \\
\text { the exam }\end{array}$ \\
\hline $\begin{array}{l}\text { Getting } \quad \text { stuck in } \\
\text { elevator }\end{array}$ & End of the world & Staying in dark $(\mathrm{f}=3)$ & Smoking \\
\hline $\begin{array}{l}\text { Breaking the heel of } \\
\text { my shoe }\end{array}$ & Being without electricity & Anxiety & Eraser \\
\hline Something lacking & $\begin{array}{l}\text { Getting stuck in elevator when } \\
\text { power goes out }\end{array}$ & $\begin{array}{l}\text { Meeting with your } \\
\text { father-in-law }\end{array}$ & Fly \\
\hline $\begin{array}{l}\text { A piece torn away from } \\
\text { me }\end{array}$ & $\begin{array}{l}\text { A kid who no longer has their } \\
\text { favorite toy }\end{array}$ & Celery meal & $\begin{array}{l}\text { Becoming naked on the } \\
\text { street }\end{array}$ \\
\hline A pointless life & Worry & Being in a coma $(\mathrm{f}=2)$ & Isolation \\
\hline Void $(\mathrm{f}=3)$ & Grief of losing a child & Horror movie $(\mathrm{f}=3)$ & A tasteless meal \\
\hline Boredom & $\begin{array}{l}\text { Keyboard with its F10 key not } \\
\text { working }\end{array}$ & $\begin{array}{l}\text { Being helpless in a very } \\
\text { deep well }\end{array}$ & Being alone $(\mathrm{f}=2)$ \\
\hline Punishment & Fenerbahçe & $\begin{array}{l}\text { My happiness stripped } \\
\text { from me }\end{array}$ & Car without wheels \\
\hline Frenzy & Imprisonment & Being out of breath & Insomnia $(\mathrm{f}=2)$ \\
\hline $\begin{array}{l}\text { Fear of being desperate } \\
(\mathrm{f}=2)\end{array}$ & $\begin{array}{l}\text { Having nothing to do without } \\
\text { knowing anything }\end{array}$ & Oxygen & Void in outer space \\
\hline Chocolate & Nothingness $(f=4)$ & $\begin{array}{l}\text { Missing the bus and } \\
\text { having to walk }\end{array}$ & Becoming lonely $(f=10)$ \\
\hline $\begin{array}{l}\text { Woman without } \\
\text { chocolate }\end{array}$ & $\begin{array}{l}\text { Falling behind my hobbies and } \\
\text { waste of time }\end{array}$ & Friend trolling the game & $\begin{array}{l}\text { Being stranded on the } \\
\text { road }\end{array}$ \\
\hline $\begin{array}{l}\text { couple who cannot } \\
\text { have child }\end{array}$ & Becoming isolated & Death $(f=3)$ & Losing the way $(\mathrm{f}=2)$ \\
\hline $\begin{array}{l}\text { Losing a friend with } \\
\text { whom I am not much }\end{array}$ & Being without light & Money (f=2) & \\
\hline
\end{tabular}




\begin{tabular}{|l|l|l|} 
close & & $\begin{array}{l}\text { Total: } \\
\text { metaphors different }\end{array}$ \\
\hline $\begin{array}{l}\text { Having no water in the } \\
\text { desert }\end{array}$ & Fear of not drinking alcohol & $\begin{array}{l}\text { Being stranded on the } \\
\text { road without money }\end{array}$ \\
\hline $\begin{array}{l}\text { Being stranded on the } \\
\text { mountain top }\end{array}$ & Primitiveness & $\begin{array}{l}\text { Worker called to work } \\
\text { on Sunday }\end{array}$ \\
\hline
\end{tabular}

According Table 7, the metaphors generated for the concept of Nomophobia considerably differed ( $\mathrm{f}=77$ ). The data obtained from the participants showed that the most repeated metaphors for the concept of Nomophobia are becoming lonely $(f=10)$ and nothingness $(f=4)$. It can be therefore argued that Nomophobia was perceived as more of a negative situation. This is why most of the participants seemed to have the fear of no mobile phone. The statements provided by the participants for their metaphors can be exemplified as follows:

P5: "Fear of desperation. Because I feel bad when I cannot hear from my friends, family, loved ones when I am without my phone."

P48: "Money. Because I become restless when I have no money."

\section{Findings on Nomophobia Metaphors Examined by Means}

Findings on the Nomophobia metaphors generated by the participants who had scores above mean $(\bar{X}=87.12)$ in the Nomophobia Questionnaire are shown in Table 5.

Table 8. Nomophobia Metaphors Generated by the Participants with Nomophobia Levels above Mean

\begin{tabular}{|c|c|c|}
\hline Category & Metaphor & Example \\
\hline $\begin{array}{l}\text { Something } \\
\text { missing }(f=28)\end{array}$ & $\begin{array}{l}\text { Insomnia, something missing, getting stuck in } \\
\text { elevator when power goes out, void, becoming a } \\
\text { widow, frenzy, void in outer space, freefalling in a } \\
\text { bottomless pit, punishment, couple who cannot } \\
\text { have child, staying in the dark, being out of breath, } \\
\text { insomnia, end of the world, a piece torn away from } \\
\text { me, becoming naked in the street, being in a coma, } \\
\text { having nothing to do without knowing anything, } \\
\text { losing my way, breaking the heel of my shoe, } \\
\text { blasting my car tire, primitiveness, child of } \\
\text { divorced parents, falling behind my hobbies and } \\
\text { waste of time, death }(f=2) \text {, staying in an indoor } \\
\text { area }(f=3)\end{array}$ & $\begin{array}{l}\text { P1: "Insomnia. Because I like } \\
\text { sleeping." }\end{array}$ \\
\hline $\begin{array}{l}\text { Restlessness } \\
(\mathbf{f}=6)\end{array}$ & $\begin{array}{l}\text { Being on a knife edge, boredom, losing my way, } \\
\text { horror movie, fear of darkness }(f=2)\end{array}$ & $\begin{array}{l}\text { P41: "Horror movie Because I } \\
\text { become nervous even though there is } \\
\text { no problem." }\end{array}$ \\
\hline $\begin{array}{l}\text { Loneliness } \\
(\mathbf{f}=\mathbf{1 0})\end{array}$ & $\begin{array}{l}\text { Being all alone, isolation, death, becoming lonely } \\
(f=7)\end{array}$ & $\begin{array}{l}\text { P6: "Death. Because life without } \\
\text { phone is meaningless for me" }\end{array}$ \\
\hline $\begin{array}{l}\text { Desperation } \\
(\mathbf{f}=5)\end{array}$ & $\begin{array}{l}\text { Having no water in the desert, fear of desperation, } \\
\text { being stranded on the road without money, entering } \\
\text { the class, imprisonment }\end{array}$ & $\begin{array}{l}\text { P51: "Imprisonment. Because I feel } \\
\text { like imprisoned somewhere when I } \\
\text { do not have my phone with me." }\end{array}$ \\
\hline
\end{tabular}




\author{
A situation Chocolate, Nothingness \\ that can be \\ accustomed to \\ $(\mathbf{f}=2)$
}

P44: "Chocolate. Because chocolate is also an addiction, but it is not that hard to quit."

The reasons for the metaphors generated for Nomophobia by the participants with Nomophobia levels below mean were reviewed, and the categories created according to these reasons were given in Table 8 . In this regard, metaphors for the concept of Nomophobia were grouped in the categories of something missing $(f=28)$, restlessness $(f=6)$, loneliness $(f=10)$, desperation $(f=5)$, and a situation that can be accustomed to $(f=2)$. It can be inferred from these categories that the participants with high levels of Nomophobia generally perceived Nomophobia as something missing. It is therefore possible to argue that being without a mobile phone makes you feel as if something was missing. On the other hand, given the categories of loneliness, restlessness and desperation, it can be said that Nomophobia was perceived as more of a negative concept that disturbs the person.

Table 9. Nomophobia Metaphors Generated by the Participants with Nomophobia Levels below Mean

\begin{tabular}{ll} 
Category & Metaphor \\
\hline $\begin{array}{l}\text { Something } \\
\text { missing }(\mathbf{f = 1 8})\end{array}$ & $\begin{array}{l}\text { Being helpless in a very deep well, my happiness } \\
\text { stripped from me, turtle, celery meal, void, being } \\
\text { without electricity, a tasteless meal, not having my } \\
\text { watch on my wrist, Fenerbahçe, being stranded on } \\
\text { the mountain top, becoming hungry, a child who no } \\
\text { longer has their favorite toy, worker called to work } \\
\text { on Sunday, being in a coma, being stranded on the } \\
\text { road, car without wheels, eraser, woman without } \\
\text { chocolate }\end{array}$
\end{tabular}

\section{Example}

$\begin{array}{ll}\begin{array}{l}\text { Restlessness } \\ (\mathbf{f}=\mathbf{1 0})\end{array} & \text { Black hole, horror movie, meeting your father-in- } \\ & \text { law, being late for the exam, anxiety, oxygen, } \\ & \text { having no eraser during the exam, money, fly }\end{array}$

P21: "Anxiety. Because it means anxiety when I cannot reach my family or they cannot reach me all day."

$\begin{array}{ll}\text { Loneliness } & \text { Being isolated, fear of being all alone, a pointless } \\ (\mathbf{f}=\mathbf{8}) & \begin{array}{l}\text { life, silence, being without light, becoming lonely } \\ (f=3)\end{array}\end{array}$

P31: "A pointless life. Because being without a phone, breaking off communication with everyone is like becoming lonely as all kinds of communication is provided via phone nowadays."

\section{Desperation} $(\mathbf{f}=\mathbf{5})$
Friend trolling the game, money, getting stuck in elevator, grief of losing a child, having nothing to do
P8: "Friend trolling the game. Because my effort would be in vain no matter how I tried; I would have nothing but anger."

\begin{tabular}{|c|c|}
\hline $\begin{array}{l}\text { A situation } \\
\text { that can be } \\
\text { accustomed to }\end{array}$ & $\begin{array}{l}\text { Horror movie, losing a friend with whom I am not } \\
\text { much close, smoking, not being able to take } \\
\text { alcohol, zucchini, missing the bus and having to } \\
\text { walk, fear of not drinking alcohol, fly, nothingness } \\
(f=3)\end{array}$ \\
\hline
\end{tabular}

P33: "Losing a friend with whom I am not much close. Because even though I am sorry, I can continue with my life without it." 
The reasons for the metaphors generated for Nomophobia by the participants with Nomophobia levels below mean were reviewed, and the categories created according to these reasons were given in Table 9. In this regard, metaphors for the concept of Nomophobia were grouped in the categories of something missing $(f=18)$, restlessness $(f=10)$, loneliness $(f=8)$, desperation $(f=5)$, and a situation that can be accustomed to $(f=11)$. It can be argued according to these categories that the participants with low Nomophobia levels perceived Nomophobia rather as something missing and a situation that can be accustomed to. That being said, the categories of restlessness, loneliness and desperation indicate that Nomophobia was perceived as more of a negative concept.

\section{Discussion and Conclusion}

Considering the cases discussed in the study and the opinions of the prospective teachers on their perceptions on these cases, it is seen that pre-service teachers attribute vital meanings to their smart phones such as friends, organs, food, needs, lovers. Considering that the metaphors obtained in relation to Nomophobia constitute the most basic needs for survival of the individual, it can be concluded that this situation related to nomophobia is a very serious psychological variable affecting the survival of the individual. Because from a psychological and social point of view, it can be said that an individual does not want to be confronted with such situation as being hungry and being deprived of his / her friends, lovers and / or organs. In particular, the lack of parameters such as meals and organs that can meet the most basic physical needs in an individual's life can affect the development of nomophobia. In the study, loneliness and nothingness" metaphors come to the fore for nomophobia, while "faaling behind and need" metaphors come to the fore for FoMo. It is known that physical needs and security exist in the first two layers of Maslow's needs hierarchy. So much so; it is expected that the individual will progress towards the steps of belonging, love, value and self-realization after meeting these needs. When performing these steps, it is important for individuals to have their self-confidence and to meet the necessities of love and approval without the need for others. However, as seen in the metaphors obtained, when a person who sees his/her smartphone as a friend and a lover feels a sense of loneliness in romantic and social relations, he/she can use his/her smartphone and social networking sites intensively to follow his friends and / or receive awards (such as likes) to get rid of this loneliness; therefore, he / she experiences a dependency syndrome and as a result, he / she can show the symptoms of nomophobic behavior. The attempt to gain an identity of the individuals who do not have selfconfidence, do not develop self-esteem and see themselves as a nothing, can mean that they are more dependent on the smartphone and virtual world. When the findings of the study are evaluated in this respect, it is possible to say that the main problem arises from the individual's inner self and his/her environment rather than stimulants in the current technological age. The findings obtained in this study can be explained by the individuals' lack of appropriate environment and education in the life cycle of the family, school and society. Because parents' dependence on the smart phone and the continuous monitoring of developments in social networking sites can be considered to be effective in this situation. In addition, it is thought that the parents exhibiting nomophobic behavior patterns will require that their children will need the unconditional love, they will create important emotions such as addiction rather than dependence, and inability to spend quality time with children will bring. In addition to meeting the basic physical and security needs, it is thought that having a proper education in terms of pedagogy, having a high level of education and having an economically adequate family structure can be beneficial in realizing the individual himself/herself. There is a great responsibility for educators as well as families in order to make individual's their own decisions and to meet their needs of love / love and self-esteem without approval. Therefore, in the light of the findings of the study, it is emphasized in this study that the addressing the thoughts of prospective teachers with smart phone metaphors and the social problems that may arise on this basis in terms of nomophobia and FoMo cases is quite important. In fact, the metaphors raised by these prospective teachers and the concerns about helping the students to perform themselves in the future are deepened with the findings of this study. In this respect, it is considered that it is necessary to take together and separately of the findings about smart phone, Nomophobia and FoMo, which are three basic trivets, to determine the reasons for the perception of the smart phone, Nomophobia and FoMO related together and separately, and to determine and the reasons for the perceptions of each situation.

\section{Results on Mobile Phone by DSUD}


According to the data obtained from the participants, the metaphors generated for the concept of mobile phone, now called smartphone, differed considerably, and the most repeated metaphors were friend, organ, eating, need, and lover. Organ, one of the most repeated among these metaphors, is more vital than the others. Losing an organ can cause an individual to die. Likewise, being in a good social and emotional relationship is important both for individual's psychology mentally and for ensuring that society is formed by healthy individuals. In addition, eating is one of individual's vital actions. An individual must eat to maintain their life. Maslow's hierarchy is underlain by the fulfillment of physiological needs. Considering that about 832 million people in the world are struggling with hunger, it is remarkable that smartphone was metaphorically described as "food" and that it could be perceived as dying when one's smartphone is not with them. It is urgent that researchers, experts, parents, school administrators, educators, families and even statesmen consider the possible consequences of this situation. Based on the metaphorical perceptions of pre-service teachers about the smart phone; the use of smart phones is thought to be quite important for individuals physically (Çakır and Oğuz, 2017), socially (Hamutoğlu et al., 2018) and psychologically (Çakır and Oğuz, 2017; Demirci vd., 2014; Enez Darcin, Kose, Noyan, Nurmedov, Y1lmaz, and Dilbaz, 2016). It can be consequently argued according to the metaphors that mobile phone was perceived by the participants rather as an essential tool of their lives. The metaphors by daily smartphone usage durations are shown in Figure 1.

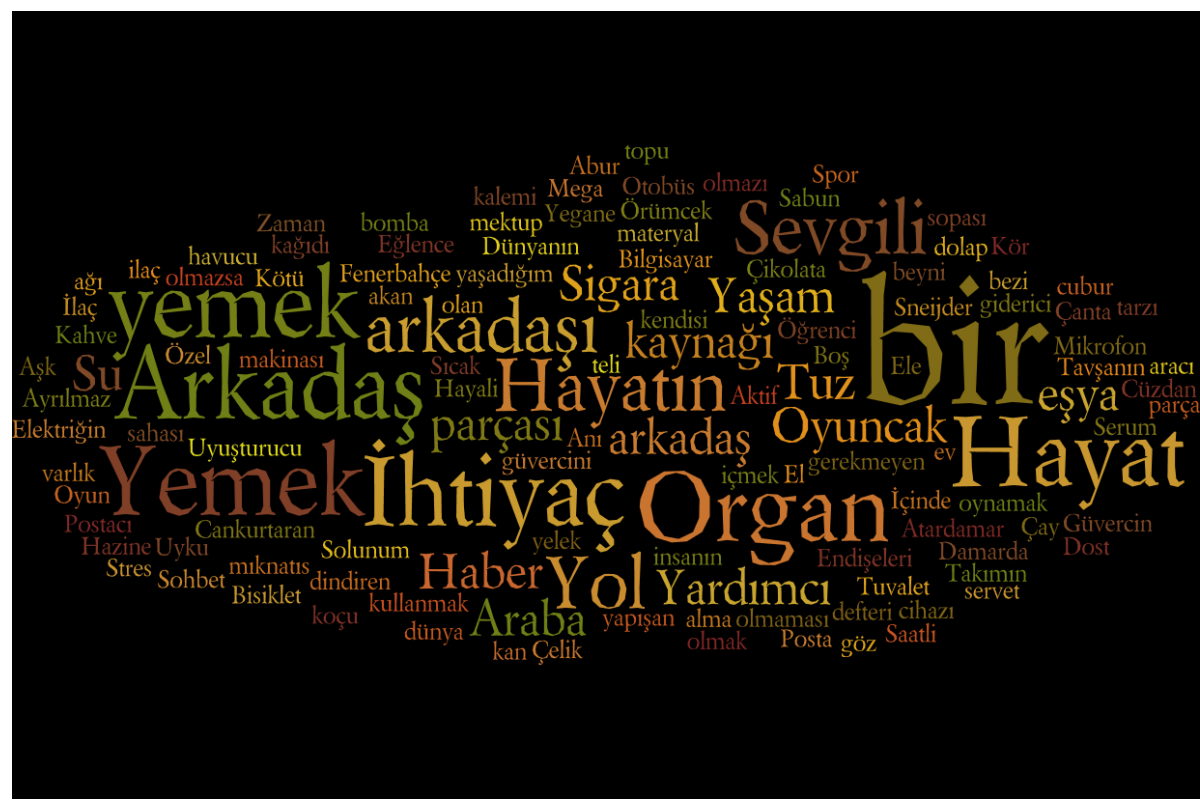

Figure 1. Metaphors by Daily Smartphone Usage Durations

\section{Results on Mobile Phone by DSUD below-above Mean}

As for participants' daily smartphone usage durations, mobile phone metaphors generated by the participants above mean were grouped in the categories of facilitation of meeting different needs, addictionindispensability and friendship whereas metaphors generated by the participants below mean were grouped in the same categories of facilitation of meeting different needs and addiction-indispensability. The categories arguably depict that smartphone is an indispensable, facilitating and friendly tool. On the other hand, mobile phone was perceived as facilitation of meeting different needs and addiction-indispensability by the participants both above and below mean. It was, however, observed in respect to the related categories that the participants above mean perceived mobile phone predominantly as addiction-an indispensable object while the participants below mean perceived it mainly as facilitation. Smartphones are technological devices that enable individuals to access everything anywhere and anytime. With applications within, students spend a lot of time on their smartphones. This time is arguably one of the factors that cause students to become dependent on smartphone. Indeed, the results indicate that the participants using smartphone above daily mean had higher levels of mobile phone addiction. In 
parallel with this finding, $\mathrm{Wu}$, Cheung, $\mathrm{Ku}$, and Hung (2013) found a significant relationship between the risk of smartphone addiction and the time spent on smartphone. The study of Smartphone Addiction Scale performed by Noyan, Enez Darçın, Nurmedov, Yılmaz, and Dilbaz (2015) found a positive significant relationship between 367 university students' smartphone addiction data and their smartphone usage durations. Demirci, Orhan, Demirdas, Akpinar, and Sert (2014) observed that the user using smartphone intensively for longer than 16 hours had higher Smartphone Addiction Scale scores than the users using smartphone for at least 4 hours or shorter than 4 hours. Lastly, Dikeç and Kebapçı (2018) also explored a positive relationship between daily smartphone usage and mean scale score in their study with 265 university students. Hence, it is possible to argue that the metaphors generated by the participants and the categories derived from these metaphors bear similarities with the literature of smartphone addiction and that intensive use of smartphones within the day consequently increases individuals' levels of smartphone addiction. Figure 2 and Figure 3 present the metaphors by daily smartphone usage durations above and below mean.

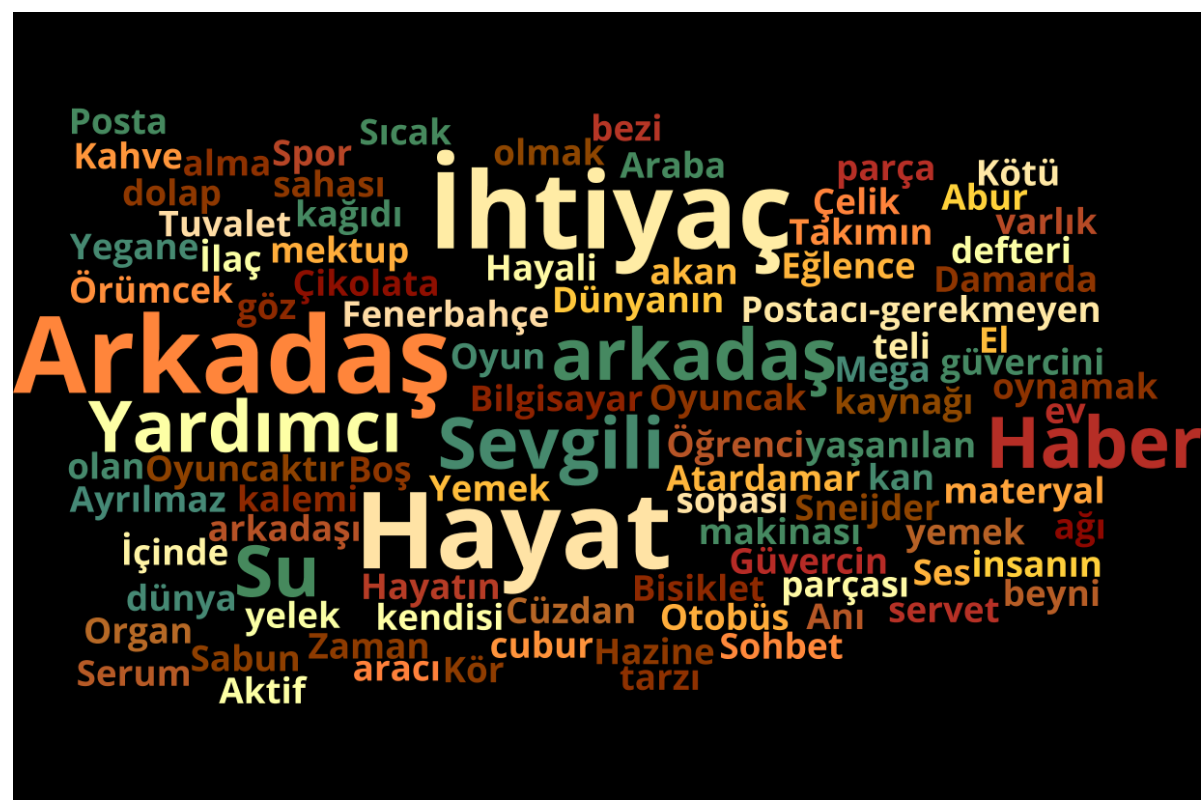

Figure 2. Metaphors by Daily Smartphone Usage Durations below Mean 


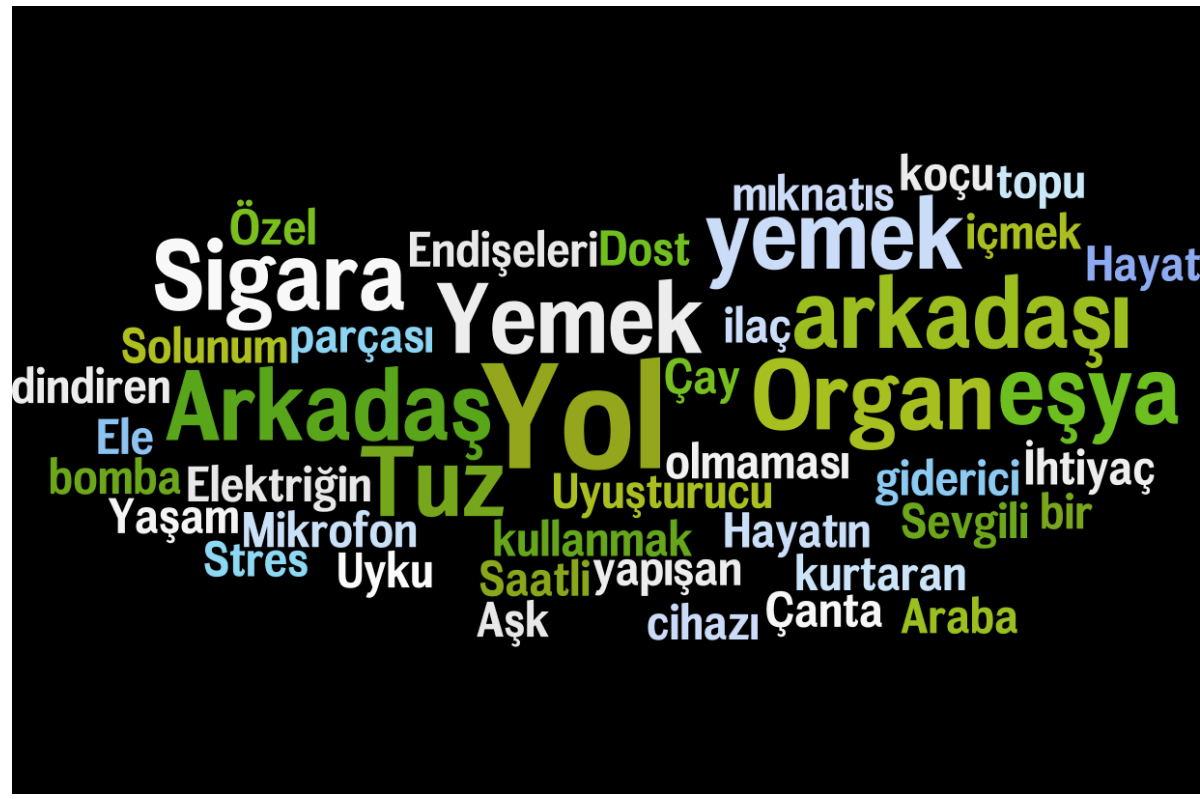

Figure 3. Metaphors by Daily Smartphone Usage Durations above Mean

\section{Results on the FoMO Metaphors}

According to the data obtained from the participants, the metaphors generated for the concept of FoMO differed sizably, and the most repeated metaphors were "falling behind the agenda, ignorant, remaining uninformed, ending up on a deserted island, and a bad incident". Considering the related metaphors, it is possible to say that FoMO was perceived as more of a negative situation, and therefore, most of the participants had the fear of missing out. The metaphors for FoMO are shown in Figure 4.

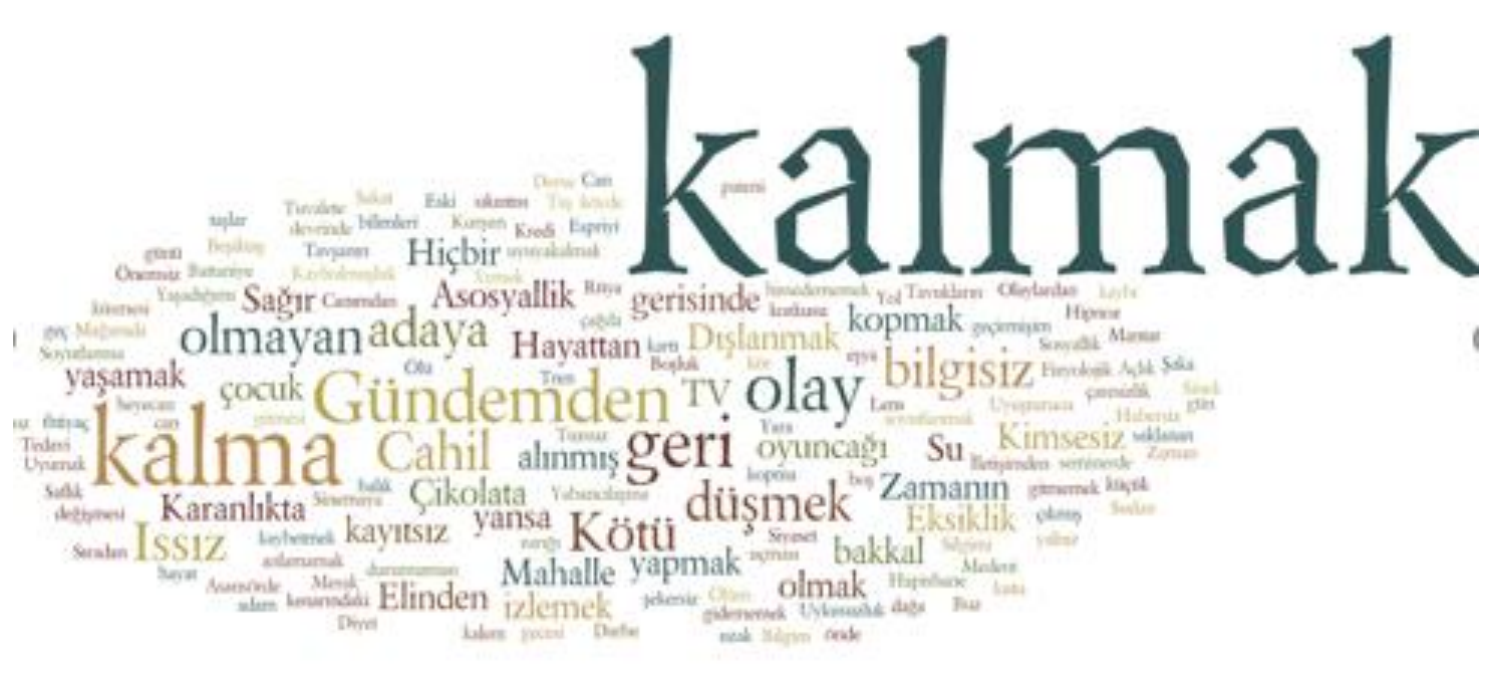

Figure 4. Metaphors for FoMO 


\section{Results on FoMO Levels below-above Mean}

According to the figure, the participants with FoMO levels both below and above mean perceived FoMO as "failing to be up to date". On the other hand, in the second place, the participants with FoMO levels above mean described FoMO as missing an indispensable action over a basic need while the participants with FoMO levels below mean described FoMO as an element that is not cared much about, without which they can continue to live. It can be argued that this result is consistent in itself given the nature of FoMO as it refers to the fear of missing out. Thus, it is arguably normal that both groups (above and below mean) perceived it as failing to be up to date in the first place. That being said, it is probably an expected case that individuals with low FoMO levels find it something that can be accustomed to as they would naturally experience the anxiety of not being able to follow up developments less frequently. FoMO emerged as a type of addiction with the increased usage of social media. Social media is recognized as one of the important factors increasing the use of social networking sites (Przybylski et al., 2013). There are also studies which identified it as one of the predictors of smartphone addiction (Gezgin, 2018). The fact that social networking sites started to be used on mobile phones with Facebook in 2004 and that mobile phones have evolved with constant development accompanied by different features has increased the time spent by individuals on social networking sites. Popular social media applications commonly used among university students today such as Instagram which has been in our lives since 2010 also play a key role in increasing individuals' daily smartphone usage durations. In a study conducted in 2012,8 out of 10 people reported that they were using social media to show who they were and boast about what they did (Laird, 2012). Now that individuals with high levels of FoMO are known to have low levels of general satisfaction, general mood, welfare and satisfaction with life (Przybylski et al., 2013). In this study, pre-service teachers' statuses associated with their FoMO levels via metaphors was explored, and the results show that individuals with high FoMO levels generally suffer from a deficiency, deprivation. Indeed, students with poor economic conditions can follow those who are living in luxury and prosperity, at least those who seem to be so, on social networks. Moreover, individuals with low levels of mood, confidence and self-esteem may want to receive the approval, which they cannot in their real life, on social networks by posting a lot. Lastly, they may enable individuals who are oppressed due to regional and cultural factors to spend much time on social networks. These situations can bring about the increase in social network usage fed by FoMO. But on the contrary, almost unlimited sources of information and connection offered by social networks would help students be informed of online events, whom to participate in these events and information used by their friends. Instead of meeting students' need for belonging on social media, it causes them to ignore this need of theirs and use social networks even more, which in return creates a vicious cycle between FoMO and social media use (Oberst, Wegmann, Stodt, Brand, and Chamarro, 2017). It is stated that this causes formal or informal interruptions and concentration disorders in students' academic lives (Alt, 2015). It can be argued from another perspective that encouraging individuals to become more of a consumer of society is among negative effects of FoMO (JWTIntelligence, 2012).In this sense, the metaphors for FoMO indicate the presence of FoMO in most of the students. Figure 5 and Figure 6 show the metaphors by FoMO levels above and below mean. 


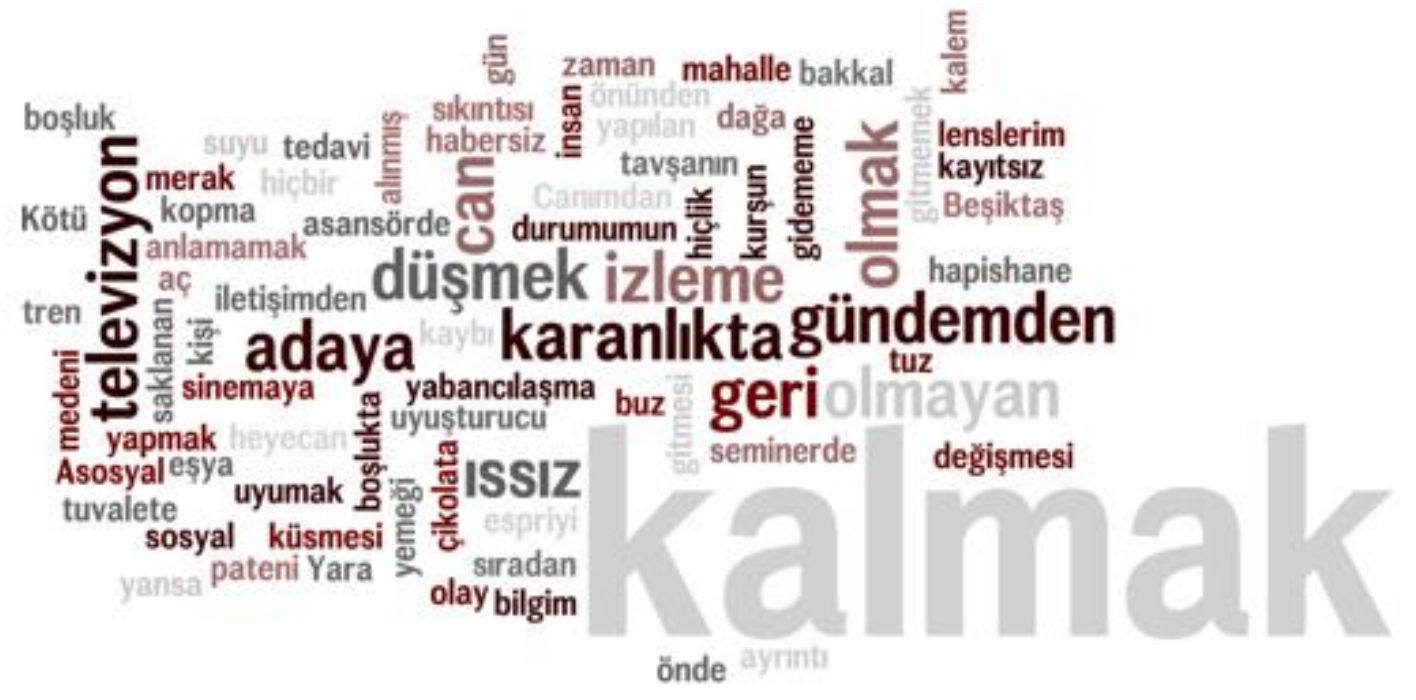

Figure 4. Metaphors by FoMO Levels below Mean

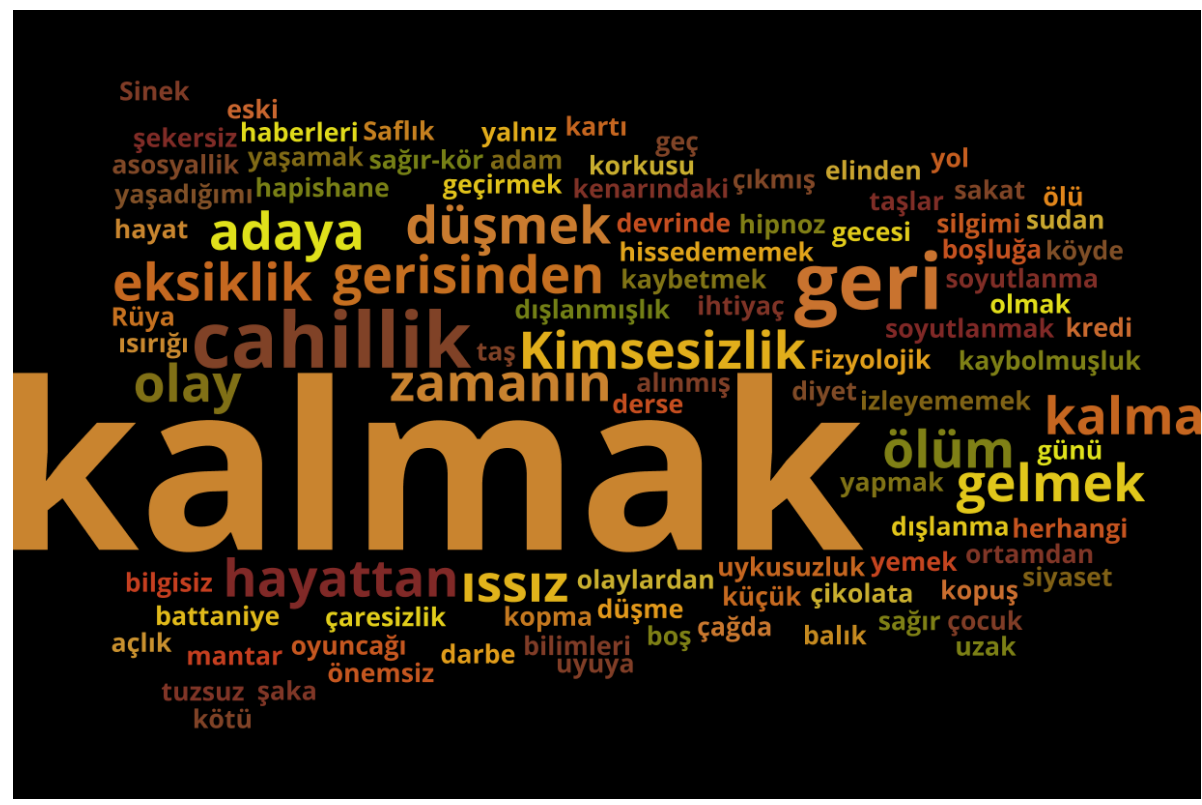

Figure 5. Metaphors by FoMO Levels above Mean

\section{Results on the Nomophobia Metaphors}

Given the data obtained from the metaphors of Nomophobia, the metaphors generated for this concept differed considerably, and the most repeated metaphors were becoming lonely and nothingness. The metaphors indicate that Nomophobia was perceived rather as a negative situation; therefore, it can be argued that most of the participants had the fear of no mobile phone. The metaphors for Nomophobia are shown in Figure 6. 


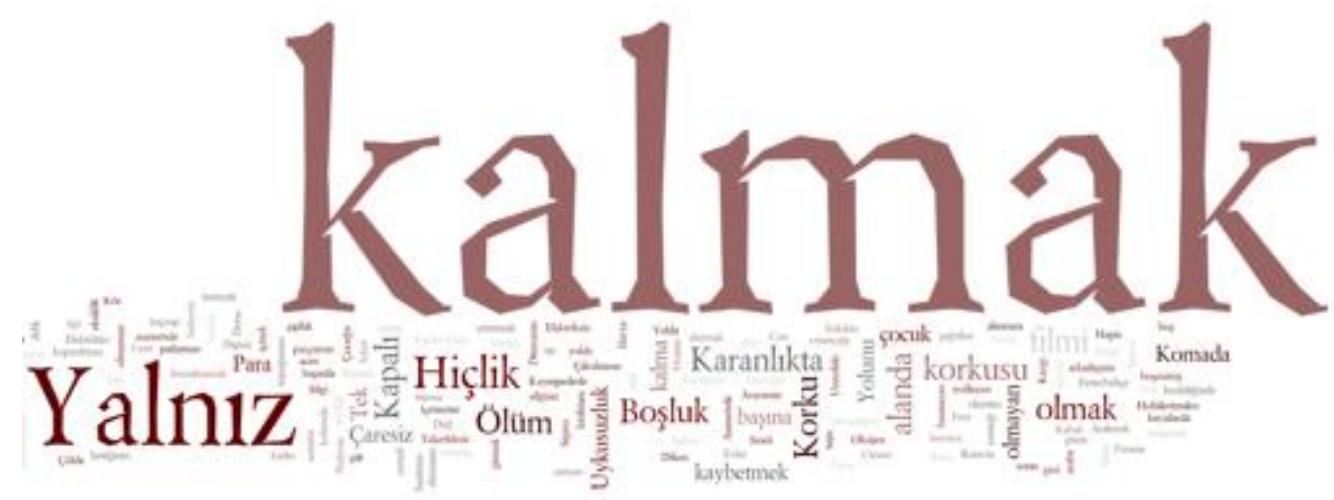

Figure 6. Metaphors for Nomophobia 


\section{Results on Nomophobia Levels below-above Mean}

Nomophobia was perceived by the participants with Nomophobia levels both below and above mean primarily as something missing. On the other hand, the participants with Nomophobia levels above mean perceived it secondly as loneliness while the participants with Nomophobia levels below mean perceived it secondly as something that can be accustomed to. It can be argued that this result is consistent in itself given the nature of Nomophobia. Indeed, it can be argued that both groups perceived Nomophobia as something missing in the first place since the concept of Nomophobia refers to the fear caused by non-availability of a mobile phone It is, however, possible to argue it is expected that individuals with low Nomophobia levels find it something that can be accustomed to as they would naturally experience the anxiety caused by absence of a mobile phone less frequently. There are studies conducted on loneliness which is a metaphor frequently repeated by the participants with high levels of Nomophobia. In a study by King et al. (2014), an experiment was performed among patients with panic attack. At the end of the experiment, the experimental group which was deprived of mobile phone reported more loneliness, insecurity and less self-esteem compared to the emotions felt by the control group. The study conducted by Durak (2018b) on 786 students concluded a moderate positive relationship between Nomophobia and loneliness. The study carried out by Ozdemir, Cakir, and Hussain (2018) on university students in Pakistan and Turkey observed a positive significant relationship between loneliness and all of the students. The study performed by Gezgin, Hamutoglu, Sezen-Gültekin, and Ayas (2018) on adolescents, in parallel with other studies, found a moderate relationship between Nomophobia and loneliness and explored loneliness as a predictor of Nomophobia. This study and the studies in the literature indicate that students sometimes feel lonely when they do not have their smartphones with them or even if they do. Figure 7 and Figure 8 show the metaphors by Nomophobia levels above and below mean.

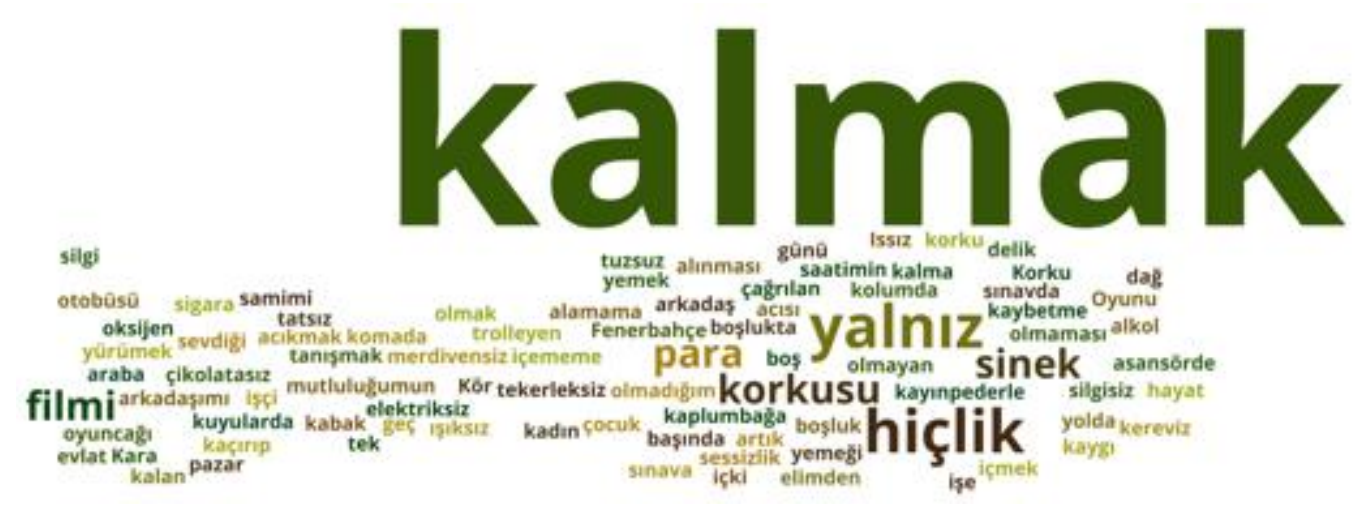

Figure 7. Metaphors by Nomophobia Levels below Mean 

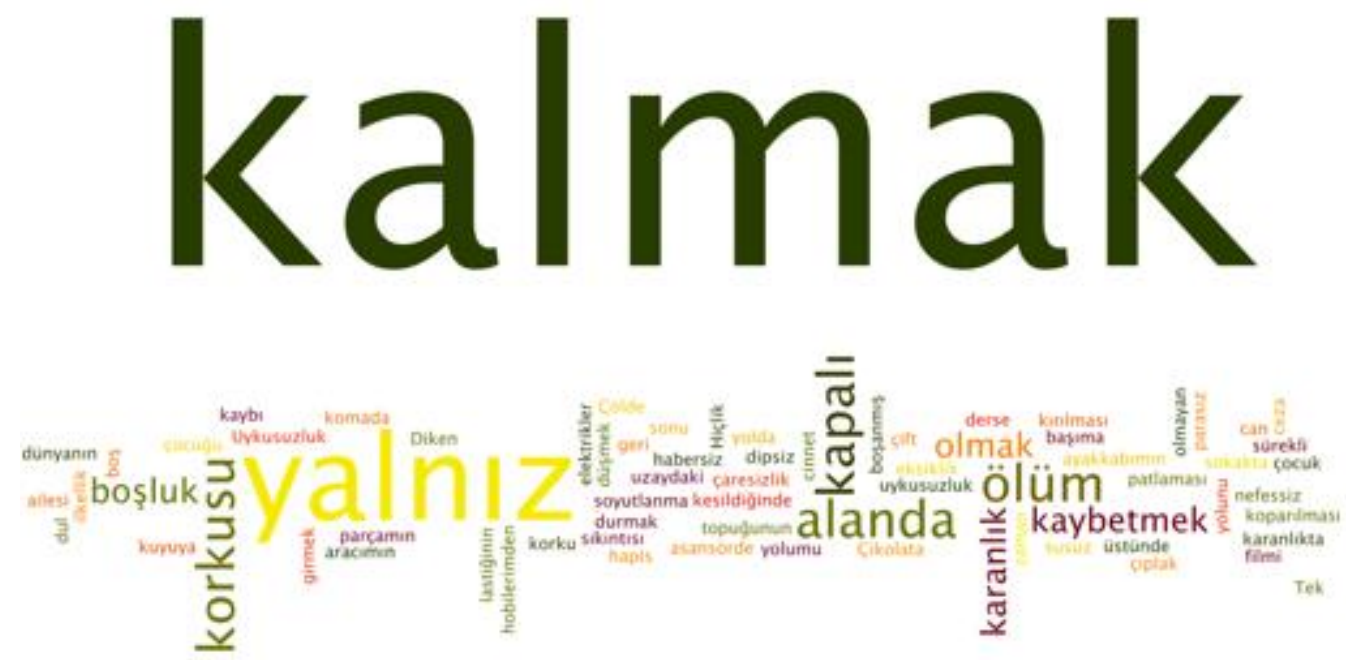

Figure 8. Metaphors by Nomophobia Levels above Mean

\section{Recommendations}

The inferences that can be made in the light of the results of the study and the relevant recommendations are listed below.

- Given the smartphone metaphors, the metaphors of friend, organ, eating, need, lover show that smartphone is almost as important as to be substituted for vital functions for the students. It can be argued that smartphones are just as essential as an organ in the life of pre-service teachers.

- The category of addiction-indispensability came to the forefront in regard to the metaphors for spending time on smartphone. Increased time spent on smartphone increases the risk of smartphone addiction. Previous studies show that smartphones are mostly used for social networks, games and entertainment. Future qualitative studies can investigate on what level the usage for mobile learning, homework and research purposes are within this intensive usage, and if low levels are found, why smartphone is not used for these purposes. Furthermore, it is possible to design a learning activity specific for each student group if students' smartphone usage durations and the application they use are identified by their characteristics.

- As for the FoMO metaphors, it was observed that FoMO was perceived predominantly as failing to be up to date. The pre-service teachers were arguably concerned that they missed out the developments. Updates on social networks, the region we live in and the financial, political, social and popular conditions might be effective on this results achieved in the study. In this respect, one can think that university students cannot maintain the lives they want and they want to exist in social networks. Future studies can find which applications and features lead to longer times spent on smartphones by identifying the relationship among smartphone usage durations, social network usage durations, social networks used and FoMO. Then, it will be possible to benefit from the results for practices and materials to be designed for educational-instructional activities. It is also thought that the results will be beneficial to academicians and teachers in utilizing the social networking sites in such activities.

- As for the Nomophobia metaphors, loneliness was found to be the most prominent metaphor used in the study. Increased loneliness of pre-service teachers causes an increase in Nomophobia. The metaphors of lover and friend also reinforce this result. The extent and type of loneliness (emotional, social and familial) can be explored by future studies. Qualitative studies can also investigate the 
reasons why university students experience the syndrome of loneliness. The results to be achieved by these studies will guide the studies on Nomophobia. It should be remembered that societies which are healthy both mentally and physically will increase the level of welfare, therefore increasing happiness. 
Gezgin, D. M., Hamutoğlu, N. B., Sezen-Gültekin, G. \& Yıldırım, S. (2019). Preservice Teachers' Metaphorical Perceptions on Smartphone, No Mobile Phone Phobia (Nomophobia) and Fear of Missing Out (FoMO). Bartın University Journal of Faculty of Education, 8(2), 733-783.

\title{
Öğretmen Adaylarının Akıllı Telefon, Mobil Telefonsuz Kalma Korkusu (Nomofobi) Ve Gelişmeleri Kaçırma Korkusuna (FoMO) İlişkin Algılarının Metafor Kullanılarak Belirlenmesi
}

\begin{abstract}
Giriş
Günümüzde mobil telefonlar artık bireylerin yaşamlarının bir parçası başka bir deyişle bir uzvu haline gelmiştir. Özellikle mobil telefon dediğimizde artık akla akıllı telefonlar gelmektedir. Neredeyse tüm uygulamaların mobil uygulamalara doğru geçiş yapması (Alfawareh ve Jusoh, 2014) ile gençler arasında akıllı telefonlar yoğunlukla kullanılmaktadır. Gençler ki -buna daha çok Y ve Z kuşağı diyebiliriz- akıllı telefonları ile özellikle sosyal medya uygulamalarını iletişim, boş zamanı doldurma, eğlence, haber takibi, eğitim araştırmaları vb. amaçlarla yoğunlukla kullanmaktadır. Akıllı telefonlar, aynı zamanda sosyal medyanın aşırı ve problemli kullanılması durumu ile gençler üzerinde bağımlılık gibi olumsuz durumların oluşmasını da beraberinde getirebilmektedir. Bu durumda genç nesil, akademik başarılarının düşmesi (Erdem, Kalkın, Türen ve Deniz, 2016; Hamutoğlu, Gezgin, Samur ve Yıldırım, 2018; Hawi ve Samaha, 2016; Samaha ve Hawi, 2016), derse olan konsantrasyonlarının azalması (Alt, 2015), yalnızlıklarının artması (Casey, 2012; Gezgin, Hamutoglu, SezenGültekin ve Ayas, 2018; Park, 2005), uyku problemleri (Demirci, Akgönül ve Akpınar, 2015; Gezgin, 2018; Hughes ve Burke, 2018; Lemola, Perkinson-Gloor, Brand, Dewald-Kaufmann ve Grob,2015) vb. gibi dolaylı olarak yaşam kalitesini olumsuz etkileyecek durumlarla karşı karşıya kalabilmektedir.

Teknoloji çağı diye de adlandırabileceğimiz içinde bulunduğumuz modern çağda bu olumsuz durumların sebebi olarak son dönemde araştırmacılar tarafından üzerinde durulan kısaca mobil telefon yoksunluğu, Nomofobi (No Mobile Phone Phobia-Nomophobia) (King, Valença, Silva, Baczynski, Carvalho ve Nardi, 2014) ve gelişmeleri kaçırma korkusu olarak ifade edilen, FoMO-Fear of Missing Out (Przybylski, Murayama ve DeHaan, 2013) iki bağımlılık türü semptomlarından bahsedilmektedir. Nomofobiye bağlı olarak gençler, akıllı telefonlarından uzak kalamamakta, akıllı telefonları kapsama alanı dışında olduğunda ve/veya akıllı telefonlarının bataryasının bitmesi durumunda panikleyerek kaygı ve korku hissedebilmektedir (Gezgin ve Akıllı, 2016). Bu durum ilerleyen zamanlarda, telefonun gencin veya bireyin yanında olmasına rağmen aynı korku ve kaygıyı yaşamasını beraberinde getirebilmektedir. Bu yüzden nomofobik davranış gösteren bireylerin davranış örüntüleri olarak sıklıkla akıllı telefonunu kontrol etme, geceleri akıllı telefonlarını kapatamama, gece yatağa akıllı telefonla girme ve herhangi bir akı1lı telefonun batarya bitmesi durumuna karșın powerbank cihazı ile gezme gibi durumlar gösterilmektedir (Akıllı ve Gezgin, 2016). FoMO'nun ise beraberinde gençlerin problemli sosyal medya kullanımını tetiklediği ortaya çıkmıștır (Franchina, Vanden Abeele, van Rooij, Lo Coco ve De Marez, 2018; Przybylski vd., 2013; Vanden Abeele ve Van Rooij, 2016). Böylelikle gençler/üniversiteliler uzaktaki aileleri ve arkadaşları ile iletişimde olmayı istemekte, ülkede gelișen olayları ve bağlantıda oldukları sosyal çevrede olup biten gelişmeleri kaçırmamak için devamlı olarak akıllı telefon uygulamalarını kullanma isteğine sahip olmaktadır. Bu durum nomofobik bireylerde olduğu gibi, gençlerin de haber kaynağındaki gelişmeleri sürekli olarak takip etmelerini, mobil uygulamalardan gelen bildirimlerini, kısacası akıllı telefonlarını sıklıkla kontrol etmelerini beraberinde getirmektedir.
\end{abstract}

Mobil uygulamaları sürekli kontrol etme davranışı kişide bir süre sonra stres ve kaygılar oluşturmakta ve genç nesil bu kaygıları çözebilmek için daha çok sosyal medya ile zaman geçirme eğilimine girmektedir. Genç nesil arasında Nomofobi ve FoMO yaygınlığını araştıran çalışmalarda bu iki rahatsızlık türünde ortaya çıkan ortak noktanın aşıı akıllı telefon, mobil internet ve sosyal medya kullanımı olduğu görülmektedir (Ak ve Yıldırım, 2018; Gezgin ve Çakır, 2016; Gezgin, Şahin ve Yıldırım, 2017; Gezgin, 2017; Gökler, Aydın, Ünal ve Metintaş, 2016). Alan yazında Nomofobi ve FoMO kavramını ele alan çalışmalar incelendiğinde nicel yöntemlerin ağırlıkla kullanıldığı, nitel çalışmaların ise neredeyse olmadığı görülmektedir. Alanyazındaki bu boşluğun doldurulması ve bireylerin akı1lı telefon, Nomofobi ve FoMO kavramlarına ilişkin algılarının nasıl değiştiğini incelemek amacıyla bu çalışmada nitel araştırma yöntemi kullanılmıştır. Çalışmada nitel araştırma yöntemi kapsamında kullanılan metafor analizinin, öğrencilerin düşünceleri açısından akıllı telefon, Nomofobi ve FoMO kavramlarını daha iyi açıklayacağı düşünüldüğünden önemli görülmektedir.

Öğretmen adaylarının akıllı telefon, Nomofobi ve FoMO kavramlarına ilişkin sahip oldukları algıları metaforlar yardımıyla belirlemeyi ve nicel bulgularla birlikte yorumlamayı amaçlayan bu araştırmada konuyla ilgili önemli sonuçlara ulaşılması düşünülmektedir. Çalışma sonuçlarının, öğrencilerin akıllı telefonları ile 
Akıllı Telefon, Nomofobi ve FoMO’ya İlişkin Metaforik Algılar

arasında kurdukları bağı tanımlayacağı ile bu tanımlardan zengin yorumlara varılacağı düşünülmektedir. Ayrıca Nomofobi ve FoMO kavramlarına yönelik elde edilecek metaforik düşüncelerin, nicel yaklaşımlarla birlikte ele alınması ileride karşılaşılabilecek olası durumlarla baş edilebilmesi açısından da önemli görülmektedir. Bununla birlikte elde edilen metaforların eğitim-öğretim faaliyetlerinde öğrencilerin mobil telefonların kullanımına ilişkin elde edilecek sonuçlara 1 şı tutabileceği düşünülmektedir. Son olarak, çalışmanın Nomofobi ve FoMO kavramlarını anlamada öğrencilerin, öğretmenlerin, yöneticilerin, ebeveynlerin ve ileride akademik çalışmalar yürütecek araştırmacıların dikkatini çekmeye yardımcı olabileceği de söz konusudur. Bu bilgiler 1şı̆̆ında, araştırmanın amacı, bir devlet üniversitesinin eğitim fakültesinde öğrenim gören öğretmen adaylarının mobil telefon, mobil telefon yoksunluğu ve sosyal ağlarda gelişmeleri kaçırma korkusu kavramlarına ilişkin sahip oldukları algıları metafor aracılığıyla belirlemek, elde edilen metaforları nicel bulgular ile yorumlamak ve alan yazında tartışmaktır.

\section{Literatür Taraması}

Nomofobi ve FoMO ile ilgili alanyazında yapılan çalışmalar her geçen gün artmaktadır. Dünya Sağlık örgütü teknolojinin insan hayatına paralel gelişmesi ile birlikte depresyon rahatsızlığının 2020 yılında dünya çapında birinci sıraya yerleşeceğini rapor etmektedir. Yaşlanmanın artmasına ilişkin istatistiksel raporda her ne kadar teknolojiden kasit edilenin ne olduğu belirtilmese de; bu durumun aslında sosyal medya, internet ve akıllı telefonlar olduğunu düşündürmektedir. Nomofobi ve FoMO ile ilgili çalışmalar alanyazında incelendiğinde çoğunlukla öğretmenler, üniversite öğrencileri ve ergenler üzerinde çalışıldığ görülmektedir. Alanda yürütülen çalışmalarda, Dağlı, Hamutoğlu ve Gezgin (2017) okul öncesi öğretmenlerinin Nomofobi düzeylerinin cinsiyet açısından anlamlı olmadığını, yaş değişkeni açısından ise negatif yönlü bir ilişkiye sahip olduğunu belirtmektedir. Dağlı, Gezgin, Hamutoğlu ve Sezen-Gültekin (2017) okul öncesi öğretmenleri ile yürütmüş oldukları çalışmada katılımcıların Nomofobi düzeylerini farklı değişkenler açısından (mobil telefon kullanımı, mobil oyun oynama, mobil oyun oynama süresi, mobil telefonu gündelik şarj etme sayısı ve öğretmenlerin kariyer evreleri) incelemiş olup; akıllı telefon kullanım süresi ve akıllı telefon şarj etme sayısının artmasının öğretmenlerin Nomofobi düzeylerini de arttırdığı sonucuna ulaşmıştır. Ayrıca çalışma bulgularında akıllı telefonlarında mobil oyun oynama ve mobil oyun oynama süresine göre Nomofobi açısından anlamlı bir farklılık söz konusu değilken; mobil telefonlarını tüm özelliklerini kullanabilme becerisinin artmasının öğrencilerin Nomofobi düzeylerini de arttığı vurgulanmaktadır. Çalışmada son olarak, öğretmenlerin Nomofobi düzeyleri ile kariyer evreleri arasında da anlamlı farklılık olduğu raporlanmaktadır.

Alanyazında nomofobinin üniversite öğrencileri arasında farklı değişkenler (akıllı telefona sahip olma, günlük akıllı telefonu kontrol etme sıklığı, mobil internete sahip olma süresi, günlük mobil internet kullanım süresi ve mobil internet kotası, cinsiyet, sınıf, yaş, düşünmeden hareket etme davranışı, başarı notu, ebeveyn eğitim durumu) açısından incelendiği çalışmaları görmek de mümkündür (Akıllı ve Gezgin, 2016; Burucuoğlu, 2017; Durak, 2018a; Erdem vd., 2016; Gezgin, 2017; Gezgin ve Çakır, 2016; Gezgin, Çakır ve Yıldırım, 2018; Gezgin, Şumuer, Arslan ve Yıldırım, 2017; Sırakaya, 2018; Yıldırım, Sumuer, Adnan ve Yıldırım, 2016). Benzer şekilde Nomofobi yaygınlığının sosyal ağ kullanıcıları üzerinde çeşitli faktörler (eğitim durumları ve mobil telefona sahip olma süreleri, akıllı telefonu günlük kontrol etme sayısı, mobil internet kullanım süresi ve günlük mobil internet kullanım süresi) açısından ele alındığı çalışmalar da söz konusudur (Gezgin, Şahin ve Yıldırım, 2017). Genç yetişkinler üzerinde Uysal, Özen ve Madenoğlu (2016) çalışmalarında Nomofobi ve sosyal fobi arasında düşük ama anlamlı bir ilişkinin varlığını tespit etmiş olup; katılımcıların Nomofobi düzeyindeki artışın sosyal fobide öngörülebilir bir artışa neden olduğunu raporlamaktadır. Sosyal fobi ve Nomofobi ile ilgili aşırı sosyal fobi rahatsızlığı olan bireyler ile yapılan başka bir çalışmada akıllı telefon ve kişisel bilgisayar sosyal fobi belirtilerini hafifletmek için bir araç olarak kullanılmaktadır. Elde edilen bulgular sosyal fobi davranışlarının akıllı telefon veya kişisel bilgisayar yoksunluğu yaşayan kişiler arasında görüldüğü ile sosyal fobi ve obsesif kompulsif bozukluklara eşlik eden bozukluklara sahip olan bireylerin nomofobiden zarar gören bireyler olduğunu göstermektedir (King vd., 2014). King ve diğerlerinin (2014) 11 adet sosyal fobiye sahip ve Nomofobi semptomları gösteren bireylerle gerçekleştirdikleri vaka çalışmalarında; sosyal fobi bozukluğu teşhisi konulan hastanın, iletişimde olduğu kişiler ile iletişim kurmada sanal ortama bağımlı olduğunu ortaya koymuş; bu durumu da kişilerle doğrudan sosyal ilişkilerden kaçınması olarak yorumlamıştır. Benzer şekilde sosyal ağları kullanan bireylerin sosyal ağlarda gelişmeleri kaçırma korkusu olarak tanımlandığı (Fuster, Chamarro ve Oberst, 2017; Gezgin, Hamutoğlu, Gemikonaklı ve Raman, 2017; Hayran, Anik ve Gürhan-Canl1, 2016). FoMO ile ilgili yapılan çalışmalara bakıldığında; FoMO'su yüksek bireylerin Facebook ile daha fazla etkileşim halinde oldukları ile düşük genel ruh hali, düşük refah ve yaşam memnuniyetine sahip oldukları belirtilmektedir (Przybylski ve diğ., 2013). FoMO ile cinsiyet, yaş, sahip olunan sosyal medya hesabı sayısı, sosyal ağ kullanma durumları ve günlük çevrimiçi 
olma durumlarını inceleyen çalışmalar da mevcuttur (Gezgin, Hamutoğlu, Gemikonaklı ve Raman, 2017; Gökler vd., 2016; Hoşgör, Tütüncü, Hoşgör ve Tandoğan, 2017). Hoşgör, Tütüncü, Hoşgör ve Tandoğan'ın (2017) üniversite öğrencileri arasındaki FoMO yaygınlığını farklı değişkenler açısından incelediği çalışmada, FoMO’ya yatkın öğrencilerin yanlarında sürekli şarj cihazı taşıdığını, uyanır uyanmaz akıllı telefonlarını kontrol ettiğini, yatağa akıllı telefonla girdiğini, her gün aktif olarak sosyal medyaya bağlandığını, akıllı telefonlarını günlük en az $50 \mathrm{kez}$ kontrol ettiğini, en az 7 yıldır bir sosyal medya hesabına sahip olduğunu, en az 4 farklı sosyal medya hesabında üyeliği bulunduğunu ve günde en az 7 saatini sosyal medyada geçirdiğini ortaya koymaktadır. Bu çalışmaya benzer şekilde FoMO'nun sosyal medya kullanımı arttığı düşüncesi altında Beyens, Frison ve Eggermont (2016) tarafından ergenler üzerinde yapılan çalışmada, ergenlerin popülarite ve ait olma ihtiyaçları ve kaybolma korkuları ile Facebook kullanımı, Facebook'ta arkadaşları arasında popüler olmama nedeniyle ve Facebook'a ait olamadıkları hissi için algılanan stres arasında güçlü pozitif ilişkiler bulunmuştur. FoMO ve aşırı sosyal medya kullanımı nedeniyle öğrencilerin ders esnasında akıllı telefonları ile zaman geçirdikleri ve derse konsantrelerinin düştüğü de rapor edilmiştir (Alt, 2015).

Alan yazında görüldüğü gibi yeni olgular olan Nomofobi ve FoMO kavramlarına yönelik yapılan çalışmalar çok hızlı bir şekilde artmaktadır. Ancak yapılan bu çalışmaların daha çok nicel araştırma desenlerine uygun olarak yürütüldüğ̈̈; çoğunlukla Nomofobi ve FoMO ile ilişkili değişkenler aracılığıyla elde edilen bulguların raporlandığı ve FoMO'nun neden olduğu semptomlar açısından ele alındığı görülmektedir. Her ne kadar Nomofobi ve FoMO kavramları ile ilgili alanyazında yapılan çalışmalar, alanyazının yeteri kadar doygunluğa ulaştığı fikrini oluştursa da; semptomları açısından birbirine çok benzer olan bu iki kavrama yönelik algıların öğrenciler tarafından ne olduğunu ele alan çalışmaların literatürde yer almadığı görülmektedir. Bu nedenle çalışmanın iki olumsuz duruma maruz kalan öğrencilerin nicel yaklaşımlar kapsamında belirlenerek; bu iki kavrama ilişkin metaforik algılarının ortaya konulmasının ilgili alanyazındaki boşluğu dolduracağı düşünülmektedir. Son olarak, elde edilen nicel ve nitel bulguların birlikte yorumlanmasının alanyazına katkı sağlayacă̆ı da söz konusudur. Böylelikle, bu çalışma aşağıdaki sorulara yanıt aramaktadır:

1. Katılımcıların akıllı telefona ilişkin metaforik algıları nedir?

1a. Katılımcıların metaforik algıları akıllı telefonu günlük kullanım sürelerine göre değişmekte midir?

2.Katılımcıların cep telefonsuz kalma (Nomofobi) durumlarına ilişkin metaforik algıları nedir?

2a. Katılımcıların metaforik algıları düşük ve yüksek Nomofobiye sahip olma durumlarına göre değişmekte midir?

3.Katılımcıların gelişmeleri kaçırma korkularına (FoMO) ilişkin metaforik algıları nedir?

3a. Katılımcıların metaforik algıları düşük ve yüksek FoMO’ya sahip olma durumlarına göre değişmekte midir?

\section{Yöntem}

Bu çalışma karma yöntem araştırmasına örnek olarak planlanmış ve yürütülmüştür. Greene, Caracelli ve Graham (1989) tarafından en az bir nicel ve bir nitel yöntem içeren araştırma tasarımları olarak tanımlanan (akt. Metin, 2015) karma yöntem araştırmaları, araştırmacının bir çalışma veya birbirini izleyen çalışmalar içerisinde nitel ve nicel yöntem, yaklaşım ve kavramları birleştirmesi olarak ele alınmakta olup (Creswell, 2003); araştırmacının, çalışmanın nicel ve nitel bileşenlerinden ayrı ayrı elde ettiği sonuçları üçgenlemesine ve böylece tek bir çalışma içinde bulguları doğrulama, destekleme veya çapraz geçerliğinin sağlanmasına firsat veren çalışmalar olarak tanımlanmaktadır (Creswell, 2013). Bu doğrultuda bu çalışma, nicel ve nitel araştırma sorularının birleştirilmesi ile verilerin aynı anda toplanması yoluyla eş zamanlı tasarım yolu ile karma yöntem biçiminde planlanmış ve yürütülmüştür.

Birinci kısım nicel araştırma yöntemlerinden tarama modeline örnek olup; elde edilen veriler farklı değişkenler açısından nedensel karşılaştırmalı olarak sunulmuştur. Tarama modelleri, geçmişte ya da halen var olan bir durumu var olduğu şekliyle betimlemeyi amaçlayan araştırma yaklaşımları olup (Karasar, 2009); nedensel 
Akıllı Telefon, Nomofobi ve FoMO’ya İlişkin Metaforik Algılar

karşılaştırma araştırmaları bireylerin ait oldukları gruplar arasında var olan mevcut farklılıkların nedenlerini veya sonuçlarını incelemeyi amaçlamaktadır (Fraenkel, Wallen veHyun, 2012). İkinci kısımda ise öğretmen adaylarının Nomofobi ve FoMO kavramlarına ilişkin algıları metaforlar yoluyla tespit edilecek olup, nitel araştırma yöntemi kullanılacak ve olgubilim (fenomoloji) ile desenlenecektir. Olgubilim deseni, farkında olduğumuz ancak derinlemesine ve ayrıntılı bir anlayışa sahip olmadığımız olgulara odaklanmaktadır. Olgular yaşadığımız dünyada olaylar, deneyimler, algılar, yönelimler, kavramlar ve durumlar gibi çeşitli biçimlerde karşımıza çıkabilmektedir (Annells, 2006; Creswell, 2013; Yıldırım ve Şimşek, 2011). Metafor çalışmaları ise araştırmacının çoklu kaynakları içeren veri toplama araçları (gözlemler, görüşmeler, görsel-işitseller, dokümanlar, raporlar) ile durumları ve duruma bağlı temaları tanımlayarak zaman içerisinde sınırlandırılmış olan bir veya birkaç durumu derinlemesine incelediği, nitel bir araştırma yaklaşımıdır (Tavşancıl ve Aslan, 2007). Olgubilim (fenomoloji) deseninin temelini bireysel tecrübeler oluşturmaktadır. Bu desende araştırmacı katılımcının öznel tecrübeleri ile ilgilenmekte, algılamaları ve olaylara yükledikleri anlamları incelemektedir. Olgubilim tanımlayıcı bir araştırmadır. Bu bağlamda genelleme yapmak değil, olguları tanımlamak önemlidir (Akturan ve Esen, 2008). Bu iki yaklaşımın bir arada kullanılması ile çalışmada sunulan araştırma probleminin daha tamamlayıcı ve bütüncül olarak ele alınacağı ve daha iyi anlaşılacağı düşünülmektedir

\section{Çalışma Grubu}

2017-2018 eğitim-öğretim yılı bahar döneminde gerçekleştirilen bu çalışmaya; Trakya bölgesinde yer alan bir devlet üniversitesinin Eğitim Fakültesinde farklı programlarda öğrenim gören 111 öğretmen adayı katılmıştır. Katılımcılardan elde edilen nicel veriler Nomofobi ve FoMO ölçeklerinden ve günlük akıllı telefon kullanma süresi değişkeninden alınan toplam puanın ortalamasına göre düşük ve yüksek olarak kategorilendirilerek her bir kategoride yer alan metaforlar belirlenmiştir. Çalışmada katılımcılar açısından gönüllülük esası aranmış ve örneklem seçiminde kolay ulaşabilir örneklem metodu kullanılmıştır.

\section{Veri Toplama Araçları}

Veriler, araştırmacılar tarafından katılımcılara dağıtılan ölçek formunu yanıtlamaları esasına dayalı olarak sınıf ortamında yüz-yüze toplanmıştır. Verilerin toplanmasında öğrencilere ilk önce çalışma konusu ile ilgili bilgilendirilmiş olup gönüllülük esas alınmış; elde edilen verilerin sadece çalışma kapsamında kullanılacağı bilgisi verilmiştir. Ölçeğin doldurulması yaklaşık olarak 10-12 dakika olarak gerçekleşmiştir. Nicel verilerin elde edilmesinde, orijinali Przybylski vd. (2013) tarafından geliştirilen ve Gökler ve ark. (2016) tarafından Türkçe'ye uyarlanan, 10 maddeden oluşan FoMO ölçeği kullanılmıştır. Bu ölçeğin yanı sıra Yıldırım ve Correia (2015) tarafından geliştirilen ve Yıldırım, Sumuer, Adnan ve Yıldırım (2016) tarafından Türkçe'ye uyarlanan, 20 maddelik Nomofobi ölçeği kullanılmıştır. Son olarak, katılımcıların metaforik algılarını belirlemek üzere araştırmacılar tarafından hazırlanan üç sorudan oluşan yapılandırılmış görüşme formu kullanılmıştır.

Nomofobi Ölçeği. Geliştirme ve uyarlama çalışmaları sonucunda elde edilen Nomofobi ölçeği 20 maddeden oluşmakta olup; 7'li Likert tipindedir. Ölçekteki maddeler 1'den (Kesinlikle Katılmıyorum) 7'ye (Kesinlikle Katılıorum) kadar derecelendirilmektedir. Nomofobi ölçeği Bilgiye Erişememe (4 madde), Bağlantıyı Kaybetme (5 madde), Iletişime Geçememe (6 madde) ve Rahat Hissedememe (5 madde) olmak üzere dört alt boyuttan oluşmaktadır. "Akıllı telefonumdan sürekli olarak bilgiye erişemediğimde kendimi rahatsız hissederim." maddesi bilgiye erişememe; "Akıllı telefonumun şarjının bitmesinden korkarım." maddesi bağlantıyı kaybetme; "Eğer akıllı telefonum yanımda değilse, Ailemle ve/veya arkadaşlarımla hemen iletişim kuramayacağım için kaygı duyarım. " maddesi iletişime geçememe ve "Çevrimiçi kimliğinden kopacağım için gergin olurum." maddesi rahat hissedememe alt boyutuna örnek teşkil etmektedir. Orijinal ölçek için Cronbach Alfa ile hesaplanan iç tutarlık katsayısı .95 iken Nomofobi ölçeğinin Türkçe'ye uyarlanan formunun iç tutarlık katsayısı değeri .92 olarak verilmektedir. Alt boyutları için orijinal ölçekte hesaplanan güvenirlik katsayıları sırası ile .94, .87, .83 ve .81 iken Türkçeye uyarlanan hali ile bu değerler $.90, .74, .94$ ve .91 şeklindedir.

Gelişmeleri Kaçırma Korkusu(FoMO) Ölçeği. FoMO ölçeği 10 maddeden oluşmakta olup; 5'li Likert tipindedir. Ölçekte yer alan her madde 1-5 puan (1=hiç doğru değildir, 5=aşırı şekilde doğrudur) arasında puanlandırılmaktadır. Ölçekten alınan puanlar 10-50 arasında değişmekte olup, ölçeğin kesim puanın olmadığ belirtilmiştir. Ölçekten alınan puanın artması "bireylerin gelişmeleri kaçırma korkusunun olma olasılığı artmaktadır" şeklinde yorumlanmaktadır. Başkalarının benimkilerden daha doyurucu deneyimler yaşadığından korkarım.” maddesi FoMO ölçeğinde yer alan maddelere örnektir. Orijinal ölçeğin Cronbach's alpha kullanılarak hesaplanan güvenirlik katsayısı .95, Türkçe’ye uyarlanmış ölçeğin güvenirlik katsayısı ise .81 olarak verilmiştir. 
Yapılandırılmış Görüşme Formu (Metafor Soruları). Araştırmada katılımcıların metaforik algılarını belirlemek üzere yöneltilen sorular araştırmacılar tarafından hazırlanmış olup katılımcılara üç farklı soru yöneltilmiştir. Buna göre birinci soru "Mobil telefon benim için... gibidir. Çünkü ...." olup katılımcıların mobil telefon ile ilgili algılarını metaforik olarak belirlemeye hizmet etmektedir. Katılımcılara yöneltilen ikinci soru ise "Mobil telefonsuz kalma korkusu benim için ... gibidir. Çünkü ..." şeklinde olup katılımcıların mobil telefon yoksunluğunda yaşadığı durumu metaforik açıdan belirlemeye yardımcı olmaktadır. Son olarak, "Gelişmeleri kaçırma (sosyal medya, olup biten olaylar vb. ile ilgili) korkusu benim için ...gibidir. Çünkü..." sorusu da katılımcıların sosyal medya ortamlarındaki gelişmeler kaçırma karşısında içinde bulundukları durumu belirlemeleri açısından yöneltilmiştir.

\section{Verilerin Analizi}

Veriler, nitel araştırma yöntemlerinden içerik analizi yaklaşımı ile analiz edilerek, nicel araştırma bulguları ile birlikte yorumlanmaktadır. Bu açıdan verilerin analizinde betimsel istatistikler ile nitel veri analizi tekniklerinden yararlanılmıştır. Elde edilen verilerin öncelikle metafor açısından uygunluğu iki farklı uzman tarafından test edilmiştir. Buna göre mobil telefona ilişkin verilen cevapların metafor açısından uygun olmamasından dolayı 9 yanıtın çalışmadan çıkarılmasına karar verilmiştir. Verilerin analizinde öncelikle katılımcılar tarafından oluşturulan her bir metafor birinci araştırmacı tarafından kodlanmıştır. Sonrasında katılımcıların verdikleri benzer anlamlar içeren kodlar bir araya getirilerek kategoriler oluşturulmuştur. Örneğin “... çünkü ........, “... çünkü ...........” vb. ifadelerden öğretmen adaylarının, mobil telefonsuz kalma korkularına ilişkin ifade ettikleri metaforlardan, mobil telefonsuz kalma korkusunu ..... olarak algıladıkları söylenebilir. Bu nedenle birinci araştırmacı tarafından kodlanan bu metaforlar "....." kategorisi altında toplanmıştır. Daha sonra ikinci araştırmacı, birinci araştırmacının yaptığı kodlamaları, oluşturduğu kategorileri inceleyerek olumlu-olumsuz görüş belirtmiştir. Verilerin güvenilirliği açısından "Güvenirlik= Görüş Birliğii/ (Görüş Ayrılığ1 + Görüş Birliği)" formülünden (Miles ve Huberman, 1994) faydalanılmış olup, araştırmacılar arasındaki uyumun kabul edilebilir düzeyde olduğu tespit edilmiştir. Ayrıca veriler Nomofobi ve FoMO alanında çalışmaları bulunan iki alan uzmanının görüşlerine başvurularak geçerlilik ve güvenilirliği kontrol ettirilmiştir. Bunun yanında katılımcıların görüşlerinden faydalanılarak doğrudan alıntıların bulgular bölümünde verilmesi ile çalışmanın geçerliliği artırılmıştır.

Daha sonra elde kalan veriler ile katılımcıların Nomofobi ve FoMO ölçeğinden almış oldukları puanlar düşük ve yüksek olarak sınıflandırılmıştır. Her bir ölçekte kategorilendirilen alanlarda, katılımcıların metaforik algıları belirlenerek farklı değişkenler açısından karşılaştırma yapılarak, birbirleri ile binişik olduğu düşünülen bu iki kavramın karşılaştırmalı olarak derinlemesine araştırılması yapılmıştır. Ayrıca katılımcıların akıllı telefona yönelik metaforik algılarının belirlenmesinde günlük akıllı telefon kullanma süresi sürekli değişkeninden elde edilen verilerden faydalanılmıştır. Buna göre, benzer şekilde, günlük akıllı telefon kullanma süresi değişkenin sunduğu verilerin ortalamasına göre katılımcıların metaforik algıları kategorilendirilmiştir.

\section{Geçerlik ve Güvenirlik}

Araştırmada görüşme sorularının anlaşılırlığı açısından, çalışma grubuna benzer bir grup ile odak grup görüşmesi yapılmıştır. Çalışmada gönüllülük esasının olması ile katılımcıların araştırma bulgularının sadece çalışma kapsamında kullanılacağı konusunda bilgilendirilmesi çalışmanın güvenirliğine hizmet etmektedir. Nitel verilerin analizinde dış geçerliği arttırmak için gözlemci üçgenlemesine gidilmiş; elde edilen veriler üç farklı uzman tarafından gözden geçirilmiştir.

\section{Bulgular}

Katılımcılardan elde edilen metaforik veriler Günlük Akıllı Telefon Kullanma Süresi (GATKS) kapsamında mobil telefon, Nomofobi ve FoMO’ya yönelik olarak ayrı başlıklar altında incelenmiştir. Ayrıca Mobil Telefon, Nomofobi ve FoMO başlıkları altında üretilen metaforlar "ortanın üstü ve altı" şeklinde ayrı alt başlıklarda incelenmiştir. Bu hususta elde edilen metaforlara ilişkin bulgular aşağıdaki gibidir.

\section{GATKS Kapsamında Mobil Telefon Metaforları}




\section{Mobil Telefon Metaforuna İlişkin Bulgular}

Mobil telefon kavramına yönelik üretilen metaforlar incelenmiş, 9 katılımcının yanıtlarının metafora uygun olmamasından dolayı ilgili 9 form analizden çıkarılarak 102 katılımcı görüşü değerlendirilmiştir. Bu değerlendirme sonucunda bazı metaforların tekrar ettiği görülmüş ve ilgili bulgular aşağıdaki tabloda sunulmuştur.

Tablo 1. Mobil Telefona Yönelik Elde Edilen Metaforlar

\begin{tabular}{|c|c|c|c|}
\hline Abur cubur & Eğlence & Kör insanın sopası & Sohbet sahası \\
\hline Aktif olmak & El bezi & Kötü bir arkadaş & Solunum cihazı \\
\hline Anı defteri & Ele yapışan mıknatıs & Mega dolap & Spor \\
\hline Araba & Elektriğin olmaması & Mikrofon & Stres topu \\
\hline Araba kullanmak & Endişeleri dindiren ilaç & Organ $(f=4)$ & $\mathrm{Su}(\mathrm{f}=2)$ \\
\hline Arkadaş (f=4) & Fenerbahçe & Otobüs & Takımın beyni olan Sneijder \\
\hline Aşk & Güvercin ve göz & Oyun oynamak & Tavşanın havucu \\
\hline Atardamar & Haber alma aracı & Oyuncak $(\mathrm{f}=2)$ & Tuvalet kâğ $\mathrm{d}_{1}$ \\
\hline Ayrılmaz bir parça & Haber kaynağ 1 & Öğrenci kalemi & Tuz $(\mathrm{f}=2)$ \\
\hline Bilgisayar & Hayali bir arkadaş & Örümcek ağ1 & Uyku \\
\hline Bisiklet & Hayat $(\mathrm{f}=2)$ & Özel eşya & Uyuşturucu \\
\hline Boş bir materyal & Hayat arkadaşı & Posta güvercini & Yardımcı $(\mathrm{f}=2)$ \\
\hline Cankurtaran & Hayat tarz1 & Postac1, gerekmeyen mektup & Yaşam koçu \\
\hline Cüzdan & Hayatın bir parçası $(\mathrm{f}=2)$ & Saatli bomba & Yaşam kaynağı \\
\hline Çanta & Hayatın olmazsa olmazı & Sabun & Yegâne varlık ve servet \\
\hline Çay & Hazine & Serum & Yemek yemek $(f=4)$ \\
\hline Çelik yelek & İçinde yaşadığım dünya & Ses teli & Yol \\
\hline Çikolata & İhtiyaç $(\mathbf{f}=3)$ & Sevgili $(\mathbf{f}=3)$ & Yol arkadaşı $(\mathrm{f}=2)$ \\
\hline Damarda akan kan & İhtiyaç giderici eşya & Sicak bir ev & Zaman makinası \\
\hline Dost & İlaç & Sigara & \multirow{2}{*}{ Toplam: $(f=82)$} \\
\hline Dünyanın kendisi & Kahve & Sigara içmek & \\
\hline
\end{tabular}

Tablo 1'e göre, mobil telefon kavramına yönelik üretilen metaforlar oldukça farklılık (f=82) göstermektedir. Katılımcılardan elde edilen verilere göre, mobil telefon kavramına ilişkin metaforlardan en fazla tekrarlananlar “arkadaş $(f=4)$, organ $(f=4)$, yemek yemek $(f=4)$, ihtiyaç $(f=3)$, sevgili $(f=3)$ ” şeklindedir. Bu durumda mobil telefonun katılımcıların hayatlarında daha ziyade bir arkadaş, sevgili ya da ihtiyaç, yemek yemek, organ gibi elzem bir araç olarak algılandığı söylenebilir. Katılımcıların ürettiği metaforlara ilişkin sunulan ifadeler aşağıdaki gibi örneklendirilebilir:

\section{K4: “Organ. Çünkü onsuz hiçbir şey yapmak mümkün değil."}

K74: "İhtiyaç. Çünkü iletişime arkadaşlarımla ailemle konuşmaya ihtiyacım var. Bu yüzden vazgeçilmezimdir."

\section{Ortalamalara Göre İncelenen Mobil Telefon Metaforlarına İlişkin Bulgular}

Katılımcılara günlük akıllı telefon kullanım süreleri sorulmuş, bu sürelerin ortalaması alınmış $(\bar{X}=6.53)$ ve bu ortalamanın üzerinde kalan 38 katılımcı ve altında kalan 64 katılımcı tarafından mobil telefon kavramına yönelik üretilen metaforlar incelenmiştir. $\mathrm{Bu}$ inceleme sonucunda elde edilen bulgular aşağıdaki tablolarda sunulmuştur.

Tablo 2. Ortalamanın Üstünde Mobil Telefon Kullanım Düzeyine Sahip Katılımcıların Ürettiği Metaforlar

Kategori Metafor Örnek




\begin{tabular}{|c|c|c|}
\hline $\begin{array}{l}\text { Farklı ihtiyaçları } \\
\text { gidermede } \\
\text { kolaylaştırıcılık }(f=12)\end{array}$ & $\begin{array}{l}\text { Aşk, Endişeleri dindiren ilaç, Yemek yemek, } \\
\text { Saatli bomba, Araba kullanmak, Ele yapışan } \\
\text { mıknatıs, Stres topu, Çanta, Yaşam koçu, } \\
\text { Mikrofon, Yol, Çay }\end{array}$ & $\begin{array}{l}\text { K86: “Mikrofon. Çünkü sesimi } \\
\text { duyurmamı kolaylaştırmamı } \\
\text { sağlar. }\end{array}$ \\
\hline $\begin{array}{l}\text { Bağımlılık-olmazsa } \\
\text { olmazlık }(f=21)\end{array}$ & $\begin{array}{l}\text { Tuz }(\mathbf{f}=\mathbf{2}) \text {, Organ }(\mathbf{f}=\mathbf{2}) \text {, Uyuşturucu, Elektriğin } \\
\text { olmamas, Hayatın bir parçası, Solunum cihazı, } \\
\text { İhtiyaç giderici eşya, Hayat, Uyku, Sigara içmek, } \\
\text { Sigara, Yemek yemek, Sevgili, Özel eşya, Yol } \\
\text { arkadaşı }\end{array}$ & $\begin{array}{l}\text { K42: "Organ. Çünkü artık bir } \\
\text { parçam ayağım, kolum gibi." }\end{array}$ \\
\hline Dostluk $(f=5)$ & Arkadaş $(\mathbf{f}=\mathbf{2})$, Cankurtaran, Yol arkadaşı, Dost & $\begin{array}{l}\text { K52: “Dost. Çünkü bütün } \\
\text { bilgilerim ve özelim onda. Mobil } \\
\text { telefon diğer insanlar gibi } \\
\text { arkadan vurmaz.” }\end{array}$ \\
\hline
\end{tabular}

Ortalamanın üstünde telefon kullanım düzeyine sahip katılımcıların ürettiği mobil telefon metaforlarına yönelik gerekçeler incelenmiş ve bu gerekçeler üzerinden oluşturulan kategoriler Tablo 2'de sunulmuştur. Bu hususta, mobil telefon kavramı farklı ihtiyaçları gidermede kolaylaştırıcılık $(f=12)$, bağımlılık-olmazsa olmazlık $(\boldsymbol{f}=\mathbf{2 1})$ ve dostluk $(\boldsymbol{f}=5)$ kategorileri altında toplanmıştır. Bu kategoriler incelendiğinde mobil telefon metaforları en çoktan en aza doğru sırasıyla bağımlılık, kolaylaştırıcılık ve dostluk olarak algılanmıştır. Bu durumda, ortalamanın üstünde telefon kullanım düzeyine sahip katılımcıların mobil telefonu daha ziyade bağımlılık yaratan, olmazsa olmaz bir unsur olarak algıladıkları söylenebilir.

Tablo 3. Ortalamanın Altında Telefon Kullanım Düzeyine Sahip Katılımcıların Ürettiği Metaforlar

\begin{tabular}{|c|c|c|}
\hline Kategori & Metafor & Örnek \\
\hline $\begin{array}{l}\text { Farklı } \\
\text { ihtiyaçları } \\
\text { gidermede } \\
\text { kolaylaştırıcılık } \\
(\mathbf{f}=\mathbf{4 1})\end{array}$ & $\begin{array}{l}\text { Arkadaş (f=3), Güvercin ve göz, Zaman } \\
\text { makinası, Araba, Öğrenci kalemi, Hayali bir } \\
\text { arkadaş, Posta güvercini, Sevgili, Boş bir } \\
\text { materyal, Haber alma aracı, Örümcek ağı, } \\
\text { Dünyanın kendisi, Oyuncak, Yardımcı, Çelik } \\
\text { yelek, İhtiyaç, Mega dolap, İlaç, Hazine, Hayat } \\
\text { tarzı, Eğlence, Kahve, Sevgili, Sohbet sahası, } \\
\text { Aktif olmak, Bilgisayar, Yardımcı, Spor, Haber } \\
\text { kaynağı, Serum, Hayat arkadaşı, Anı defteri, } \\
\text { Oyuncaktır, Bisiklet, Oyun oynamak, El bezi, } \\
\text { Otobüs, Ses teli, Postac1-gerekmeyen mektup }\end{array}$ & $\begin{array}{l}\text { K54:" Serum. Çünkü bir günde dünyada } \\
\text { neler olup bitti gelişmeler benim için } \\
\text { önemlidir. Tüm günlük işler, iletişi, bilgi } \\
\text { bunun üzerinden gerçekleşir, hayatımızı } \\
\text { kolaylaştırır. }\end{array}$ \\
\hline $\begin{array}{l}\text { Olmazsa } \\
\text { olmazlık, } \\
\text { bağımlılık } \\
(\mathbf{f}=23)\end{array}$ & $\begin{array}{l}\text { İhtiyaç (f=2), Yemek yemek, Yegane varlık ve } \\
\text { servet, Abur cubur, Cüzdan, Çikolata, Damarda } \\
\text { akan kan, Hayat, Takımın beyni olan Sneijder, } \\
\text { Hayatın bir parçası, Kör insanın sopası, Su, } \\
\text { İçinde yaşanılan dünya, Kötü bir arkadaş, } \\
\text { Atardamar, Sıcak bir ev, Organ, Ayrılmaz bir } \\
\text { parça, Su, Sabun, Fenerbahçe, Tuvalet kağıdı }\end{array}$ & $\begin{array}{l}\text { K58:" Takımımınız beyni olan Sneijder. } \\
\text { Çünkü olmazsa olmaz hayatımızın tam } \\
\text { ortasında aslında bizi yönlendiriyor. } \\
\text { Hayatımızın merkezinde diyebiliriz. } \\
\text { Mesela telefon yokken ya da şarjı bitince } \\
\text { boşluktaymışsın gibi oluyor. Aynısı } \\
\text { Sneijder içinde geçerli o olmadığında } \\
\text { olmuyor. Bir şey eksik oluyor.” }\end{array}$ \\
\hline
\end{tabular}

Ortalamanın altında telefon kullanım düzeyine katılımcıların ürettiği mobil telefon metaforlarına yönelik gerekçeler incelenmiş ve bu gerekçeler üzerinden oluşturulan kategoriler Tablo 3 'te sunulmuştur. Bu hususta, mobil telefon kavramı farklı ihtiyaçları gidermede kolaylaştırıcılık $(f=41)$ ve olmazsa olmazlık- bağımlılık $(f=23)$ kategorileri altında toplanmıştır. Bu kategoriler incelendiğinde telefon kullanım düzeyi düşük olan katılımcıların 
Akıllı Telefon, Nomofobi ve FoMO’ya İlişkin Metaforik Algılar mobil telefonu daha ziyade farklı ihtiyaçları (iletişim, gündemi takip etme vb.) karşılamada bir kolaylaştırıcı unsur olarak algıladıkları söylenebilir.

\section{FoMO Metaforuna İlişsin Bulgular}

FoMO kavramına yönelik üretilen metaforlar incelendiğinde bazı FoMO’ya yönelik metaforların tekrar ettiği görülmektedir. FoMO’ya ilişkin bulgular aşağıdaki tablo 4 'de sunulmuştur.

Tablo 4. FoMO’ya Yönelik Elde Edilen Metaforlar

\begin{tabular}{|c|c|c|c|}
\hline Açlık & Espriyi anlamamak & $\begin{array}{l}\text { Medeni durumumun } \\
\text { değişmesi }\end{array}$ & Şaka \\
\hline Asansörde kalmak & Fizyolojik bir ihtiyaç & Merak ve heyecan & $\begin{array}{l}\text { Taş devrinde } \\
\text { yaşamak }\end{array}$ \\
\hline Asosyallik $(\mathrm{f}=2)$ & $\begin{array}{l}\text { Gündemden geri kalmak } \\
(f=4)\end{array}$ & O günü boş geçirmişim & $\begin{array}{l}\text { Tavşanın } \quad \text { dağa } \\
\text { küsmesi }\end{array}$ \\
\hline Battaniye & Habersiz kalmak & $\begin{array}{l}\text { Olaylardan uzak kalma, } \\
\text { çaresizlik }\end{array}$ & Tavukların uçması \\
\hline $\begin{array}{l}\text { Benden saklanan bir } \\
\text { kutu eşya }\end{array}$ & Hapishane & Ölü adam & Tedavi \\
\hline Beşiktaş & Hayattan kopmak $(\mathrm{f}=2)$ & Ölüm & Tren \\
\hline $\begin{array}{l}\text { Bilgim olmayan } \\
\text { seminerde en önde } \\
\text { olmak }\end{array}$ & Her şeyden soyutlanmak & Önemsiz bir olay & $\begin{array}{l}\text { Tuvalete } \\
\text { gidememek }\end{array}$ \\
\hline $\begin{array}{l}\text { Bir köyde yalnız } \\
\text { kalmak }\end{array}$ & Hiçbir şey $(f=2)$ & Rüya & Tuz \\
\hline Boşluk & Hipnoz & Saflık & $\begin{array}{l}\text { Tuzsuz şekersiz bir } \\
\text { hayat }\end{array}$ \\
\hline Buz pateni yapmak & Issız adaya düşmek $(f=3)$ & Sağır olmak & TV izlemek $(\mathrm{f}=2)$ \\
\hline $\begin{array}{l}\text { Cahil, bilgisiz kalmak } \\
(f=3)\end{array}$ & İletişimden kopma & Sağır, kör kalmak & Uykusuzluk \\
\hline Can s1kıntısı & Karanlıkta kalmak $(\mathrm{f}=2)$ & Sakat kalmak & Uyumak \\
\hline Canımdan can gitmesi & Kaybolmuşluk & Siradan bir gün & Uyuşturucu \\
\hline Çikolata $(\mathrm{f}=2)$ & Kimsesiz kalmak $(\mathrm{f}=2)$ & Silgimi kaybetmek & Yabancılaşma \\
\hline $\begin{array}{ll}\text { Darbe } & \text { gecesi } \\
\text { uyuyakalmak } & \end{array}$ & Kötü bir olay $(f=3)$ & Sinek 1Sırı & Yara \\
\hline
\end{tabular}




\begin{tabular}{|l|l|l|l|}
$\begin{array}{l}\text { Derse geç kalma } \\
\text { korkusu }\end{array}$ & Kredi kartı & Sinemaya gitmemek & $\begin{array}{l}\text { Yaşadığımı } \\
\text { hissedememek }\end{array}$ \\
\hline Dışlanmak (f=2) & Kurşun kalem & Siyaset bilimleri & Yemek \\
\hline Diyet yapmak & Lens & Sosyallik & $\begin{array}{l}\text { Yol kenarındaki } \\
\text { küçük taşlar }\end{array}$ \\
\hline Eksiklik (f=2) & Mağarada yaşamak & Soyutlanma & Zaman kaybı \\
\hline $\begin{array}{l}\text { Elinden çuncağ1 } \\
\text { alınmış çocuk }\end{array}$ & Mahalle yansa kayıtsız kalma & Su olmayan bakkal & $\begin{array}{l}\text { Zamanın gerisinde } \\
\text { kalma (f=2) }\end{array}$ \\
\hline Eski çağda kalmak & Mantar & Sudan çıkmış balık & $\begin{array}{l}\text { Toplam: } \\
\text { metafor }\end{array}$ \\
\hline
\end{tabular}

Tablo 4’te göre, FoMO kavramına yönelik üretilen metaforlar oldukça farklılık (f=83) göstermektedir. Katılımcılardan elde edilen verilere göre, FoMO kavramına ilişkin metaforlardan en fazla tekrarlananlar "gündemden geri kalmak $(f=4)$, cahil, bilgisiz kalmak $(f=3)$, ıssız adaya düssmek $(f=3)$, kötü bir olay $(f=3)$ " şeklindedir. Bu durumda FoMO'nun daha ziyade olumsuz bir durum olarak algılandığı söylenebilir. Bu sebeple, katılımcıların çoğunun gelişmeleri kaçırma korkusuna sahip olduğu söylenebilir. Katılımcıların ürettiği metaforlara ilişkin sunulan ifadeler aşağıdaki gibi örneklendirilebilir:

K58: “Diyet yapmak. Çünkü tadı yoktur hayatın.”

K5: "Issız bir adaya düşmek. Çünkü iki durumda da dünyadan, çevremden haberdar olamayacak gibi oluyorum."

\section{Ortalamalara Göre İncelenen FoMO Metaforlarına İlişkin Bulgular}

FoMO ölçeğinden alınan puan ortalamasının üstünde $(\bar{X}=28,93)$ FoMO düzeyine sahip katılımcıların FoMO kavramına ilişsin ürettiği metaforlara ilişkin bulgular Tablo 5'de gösterilmektedir.

Tablo 5. Ortalamanın Üstünde FoMO Düzeyine Sahip Katılımcıların Ürettiği FoMO Metaforları

\begin{tabular}{|c|c|c|}
\hline Kategori & Metafor & Örnek \\
\hline $\begin{array}{l}\text { Gereksinim } \\
(\mathbf{f}=\mathbf{1 5})\end{array}$ & $\begin{array}{l}\text { Fizyolojik bir ihtiyaç, sakat kalmak, derse geç } \\
\text { kalma korkusu, yemek, eksiklik, açlık, uykusuzluk, } \\
\text { günü boş geçirmek, ölüm, tuzsuz şekersiz bir hayat, } \\
\text { kredi kartı, hayattan kopma, silgimi kaybetmek, } \\
\text { diyet yapmak, sudan çımış balık }\end{array}$ & $\begin{array}{l}\text { K1: "Fizyolojik bir ihtiyaç. Çünkü } \\
\text { beynimin bir köşesinde sürekli sosyal } \\
\text { medyada olup bitenler yer alır." }\end{array}$ \\
\hline
\end{tabular}


Geri kalma Saflık, kaybolmuşluk, herhangi bir ortamdan (f=32) dişlanma, boşluğa düşme, soyutlanma, siyaset bilimleri, eksiklik, sağır-kör kalmak, ölüm, kötü bir olay, sağır olmak, taş devrinde yaşamak, hayattan kopuş, olaylardan uzak kalma, çaresizlik, darbe gecesi uyuya kalmak, bilgisiz kalmak, hapishane, eski çağda kalmak, asosyallik, yaşadığımı hissedememek, ölü adam, cahillik $(f=3)$, geri kalmak ( $f=3)$, zamanin gerisinden gelmek $(f=2)$, issız adaya düşmek $(f=2)$
K40: "Ölü adam, her olaydan geri kalmak, bilgisiz kalmak. Çünkü çevremdeki insanlart takip edememe ve onlarla bir araya geldiğimde yaptıklart hakkında fikir sahibi olmamama neden olur."

\begin{tabular}{|c|c|c|}
\hline $\begin{array}{l}\text { Hayal } \\
\text { kırıklığı } \\
(\mathbf{f}=4)\end{array}$ & Rüya, elinden oyuncağı alınmış çocuk, hipnoz, şaka & $\begin{array}{l}\text { K12: "Elinden oyuncă̆ alınmış } \\
\text { çocuk. Çünkü canım çok sıkılır } \\
\text { istediğim ve ĕglendiğim şeyleri } \\
\text { yapamam." }\end{array}$ \\
\hline $\begin{array}{l}\text { Yalnızlık } \\
(\mathbf{f}=5)\end{array}$ & $\begin{array}{l}\text { Kimsesizlik }(f=2) \text {, bir köyde yalnız kalmak, } \\
\text { dışlanmışlık, her şeyden soyutlanmak }\end{array}$ & $\begin{array}{l}\text { K7: "Kimsesizlik. Çünkü hiçbir } \\
\text { şeyden haberdar olmayınca yalnız } \\
\text { gibi hissederim." }\end{array}$ \\
\hline $\begin{array}{l}\text { Alışılabilir } \\
\text { bir durum } \\
(f=7)\end{array}$ & $\begin{array}{l}\text { Sinek isırığı, mantar, önemsiz bir olay, yol } \\
\text { kenarındaki küçük taşlar, haberleri izleyememek, } \\
\text { battaniye, çikolata }\end{array}$ & $\begin{array}{l}\text { K54: "Battaniye. Çünkü olmasa da } \\
\text { olur sadece daha az ısınırsınız benim } \\
\text { için de öyle." }\end{array}$ \\
\hline
\end{tabular}

Ortalamanın üstünde FoMO düzeyine sahip katılımcıların ürettiği FoMO metaforlarına yönelik gerekçeler incelenmiş ve bu gerekçeler üzerinden oluşturulan kategoriler Tablo 5 'te sunulmuştur. Bu hususta, FoMO kavramı gereksinim $(f=15)$, geri kalma $(f=32)$, hayal kırıklı̆̆ $(f=4)$, yalnızlık $(f=5)$ ve alışılabilir bir durum $(f=7)$ kategorileri altında toplanmıştır. Bu kategoriler incelendiğinde FoMO düzeyi yüksek olan katılımcıların FoMO’yu daha ziyade bir şeylerden geri kalma ve en temel ihtiyaçlardan eksik kalma biçiminde algıladıkları söylenebilir.

Tablo 6. Ortalamanın Altındaki FoMO Düzeyine Sahip Katılımcıların Ürettiği FoMO Metaforları

\begin{tabular}{|c|c|c|}
\hline Kategori & Metafor & Örnek \\
\hline $\begin{array}{l}\text { Gereksinim } \\
(\mathbf{f}=9)\end{array}$ & $\begin{array}{l}\text { Canımdan can gitmesi, çikolata, medeni } \\
\text { durumumun değişmesi, lenslerim, ayrıntı, merak ve } \\
\text { heyecan, tuz, tedavi, tuvalete gidememe }\end{array}$ & $\begin{array}{l}\text { K1: "Canımdan can gitmesi. Çünkü } \\
\text { artık bağımlılık derecesindeyiz onsuz } \\
\text { vakit geçiremiyoruz." }\end{array}$ \\
\hline $\begin{array}{l}\text { Geri kalma } \\
(\mathbf{f}=\mathbf{2 0})\end{array}$ & $\begin{array}{l}\text { Kötü bir olay, uyumak, saklanan eşya, asansörde } \\
\text { kalmak, suyu olmayan bakkal, boşlukta kalmak, } \\
\text { yapılan espriyi anlamamak, tren, iletişimden } \\
\text { kopma, habersiz kalmak, can sıkıntısı, yemeği } \\
\text { önünden alınmış aç bir insan, bilgim olmayan } \\
\text { seminerde en önde olmak, hapishane, gündemden } \\
\text { geri kalmak ( } \mathrm{f}=2) \text {, karanlıkta kalmak (f=2), 1ssız bir } \\
\text { adaya düşmek (f=2) }\end{array}$ & $\begin{array}{l}\text { K51:"Hapishane. Çünkü olayları } \\
\text { kaçırmamak benim için önemlidir." }\end{array}$ \\
\hline $\begin{array}{l}\text { Yalnızlık } \\
(\mathbf{f}=2)\end{array}$ & Asosyal bir kişi, yabancılaşma & $\begin{array}{l}\text { K25: "Yabancılaşma. Çünkü çevreyle } \\
\text { kopukluk yaşanır." }\end{array}$ \\
\hline
\end{tabular}


Alıșılabilir Yara, mahalle yansa kayıtsız kalmak, sıradan bir bir durum gün, uyuşturucu, Beşiktaş, hiçlik, kurşun kalem, $(\mathbf{f}=16)$ sinemaya gitmemek, hiçbir şey, buz pateni yapmak, boşluk, zaman kaybı, daha sosyal olmak, tavşanın dağa küsmesi, televizyon izleme $(\mathrm{f}=2)$
K4: "Yara. Çünkü en bașta bir yara acıtır ama daha sonra kabuk bağlar ve eskisi gibi act vermezse gelişmeleri kaçırmak da bu etkiyi yaratır, önce bir boșluk ama daha sonra alışılmışlık olur."

Ölçekten alınan puan ortalamasının altında FoMO düzeyine sahip katılımcıların ürettiği FoMO metaforlarına yönelik gerekçeler incelenmiş ve bu gerekçeler üzerinden oluşturulan kategoriler Tablo 6'da sunulmuştur. Bu hususta, FoMO kavramı gereksinim $(f=9)$, geri kalma $(f=20)$, yalnızlık $(f=2)$ ve alışılabilir bir durum $(\boldsymbol{f}=\mathbf{1 6})$ kategorileri altında toplanmıştır. Bu kategoriler incelendiğinde FoMO düzeyi düşük olan katılımcıların FoMO'yu daha ziyade bir şeylerden geri kalma ve alışılabilir bir durum biçiminde algıladıkları söylenebilir.

\section{Nomofobi Metaforlara İlişkin Bulgular}

Nomofobi kavramına yönelik üretilen metaforlar incelendiğinde bazılarının tekrar ettiği görülmektedir. Bu metaforlara ilişkin bulgular aşağıdaki tablo 7'de sunulmuştur.

Tablo 7. Nomofobi'ye Yönelik Elde Edilen Metaforlar

\begin{tabular}{|c|c|c|c|}
\hline Acıkmak & Derse girmek & Kabak & $\begin{array}{l}\text { Saatimin } \quad \text { kolumda } \\
\text { olmamasi }\end{array}$ \\
\hline Ailesi boşanmış çocuk & Diken üstünde durmak & $\begin{array}{l}\text { Kapalı alanda kalmak } \\
(\mathrm{f}=3)\end{array}$ & Sessizlik \\
\hline Alkol alamama & $\begin{array}{l}\text { Dipsiz bir kuyuya sürekli } \\
\text { düşmek }\end{array}$ & Kaplumbağa & Sınava geç kalmak \\
\hline $\begin{array}{l}\text { Aracımın lastiğinin } \\
\text { patlaması }\end{array}$ & Dul kalmak & Kara delik & Sinavda silgisiz kalmak \\
\hline Asansörde kalmak & Dünyanın sonu & Karanlıkta kalmak $(\mathrm{f}=3)$ & Sigara içmek \\
\hline $\begin{array}{l}\text { Ayakkabımın } \\
\text { topuğunun kırılması }\end{array}$ & Elektriksiz kalmak & Kayg1 & Silgi \\
\hline Bir eksiklik & $\begin{array}{l}\text { Elektrikler kesildiğinde } \\
\text { asansörde kalmak }\end{array}$ & Kayınpederle tanışmak & Sinek \\
\hline $\begin{array}{ll}\text { Bir } & \text { parçamın } \\
\text { koparılması } & \end{array}$ & $\begin{array}{l}\text { En sevdiği oyuncağı artık } \\
\text { olmayan bir çocuk }\end{array}$ & Kereviz yemeği & Sokakta çıplak kalmak \\
\hline Boş hayat & Endişe & Komada olmak $(\mathrm{f}=2)$ & Soyutlanmak \\
\hline Boşluk ( $f=3$ ) & Evlat acis1 & Korku filmi $(\mathrm{f}=3$ ) & Tatsiz tuzsuz bir yemek \\
\hline Can sıkıntıs1 & F 10 tuşu basmayan klavye & $\begin{array}{l}\text { Kör kuyularda } \\
\text { merdivensiz kalmak }\end{array}$ & Tek başına kalmak $(f=2)$ \\
\hline
\end{tabular}




\begin{tabular}{|c|c|c|c|}
\hline Ceza & Fenerbahçe & $\begin{array}{l}\text { Mutluluğumun elimden } \\
\text { alınması }\end{array}$ & Tekerleksiz araba \\
\hline Cinnet & Hapis & Nefessiz kalmak & Uykusuzluk (f=2) \\
\hline $\begin{array}{l}\text { Çaresiz kalma korkusu } \\
(\mathrm{f}=2)\end{array}$ & Her şeyden habersiz boş olmak & Oksijen & Uzaydaki boşluk \\
\hline Çikolata & Hiçlik $(f=4)$ & $\begin{array}{l}\text { Otobüsü } \quad \text { kaçırıp } \\
\text { yürümek }\end{array}$ & Yalnız kalmak $(f=10)$ \\
\hline Çikolatasız kalan kadın & $\begin{array}{l}\text { Hobilerimden geri kalmak ve } \\
\text { zaman kaybı }\end{array}$ & $\begin{array}{l}\text { Oyunu trolleyen } \\
\text { arkadaş }\end{array}$ & Yolda kalmak \\
\hline Çocuğu olmayan çift & Issiz kalmak & Ölüm (f=3) & $\begin{array}{l}\text { Yolunu kaybetmek } \\
(\mathrm{f}=2)\end{array}$ \\
\hline $\begin{array}{l}\text { Çok samimi olmadığım } \\
\text { arkadaşımı kaybetme }\end{array}$ & Işıksız kalmak & Para $(\mathrm{f}=2)$ & \multirow{3}{*}{$\begin{array}{l}\text { Toplam: } \\
\text { metafor }\end{array}$} \\
\hline Çölde susuz kalmak & İçki içememe korkusu & Parasız yolda kalmak & \\
\hline Dağ başında kalmak & İlkellik & $\begin{array}{l}\text { Pazar günü işe çağrılan } \\
\text { işçi }\end{array}$ & \\
\hline
\end{tabular}

Tablo 7'ye göre, Nomofobi kavramına yönelik üretilen metaforlar oldukça farklılık (f=77) göstermektedir. Katılımcılardan elde edilen verilere göre, Nomofobi kavramına ilişkin metaforlardan en fazla tekrarlananlar “yalnız kalmak $(f=10)$, hiçlik $(f=4)$ ” şeklindedir. Bu durumda Nomofobinin daha ziyade olumsuz bir durum olarak algılandığı söylenebilir. Bu sebeple, katılımcıların çoğunun mobil telefonsuz kalma korkusuna sahip olduğu söylenebilir. Katılımcıların ürettiği metaforlara ilişkin sunulan ifadeler aşağıdaki gibi örneklendirilebilir:

K5: “Çaresizlik korkusu. Çünkü telefonsuz kalınca arkadaşlarımdan, ailemden, sevdiklerimden haber alamayınca kötü hissediyorum."

K48: “Para. Çünkü param olmadı̆̆ında huzursuz olurum.”

\section{Ortalamalara Göre İncelenen Nomofobi Metaforlarına İlişkin Bulgular}

Nomofobi ölçeğinden alınan puan ortalamasının üstünde $(\bar{X}=87,12)$ Nomofobi düzeyine sahip katılımcıların Nomofobi kavramına ilişkin ürettiği metaforlara ilişkin bulgular aşağıdaki gibidir.

Tablo 8. Ortalamanın Üstünde Nomofobi Düzeyine Sahip Katılımcıların Ürettiği Nomofobi Metaforları

\begin{tabular}{lll}
\hline Kategori Metafor Örnek \\
\hline
\end{tabular}




$\begin{array}{ll}\text { Eksiklik } & \text { Uykusuzluk, eksiklik, elektrikler kesildiğinde } \\ \text { (f=28) } & \text { asansörde kalmak, boşluk, dul kalmak, cinnet, } \\ & \text { uzaydaki boşluk, dipsiz bir kuyuya sürekli düşmek, } \\ & \text { ceza, çocuğu olmayan çift, karanlıkta kalmak, } \\ & \text { nefessiz kalmak, uykusuzluk, dünyanın sonu, bir } \\ \text { parçamı koparılması, sokakta çılak kalmak, } & \text { komada olmak, her şeyden habersiz boş olmak, } \\ & \text { yolumu kaybetmek, ayakkabımın topuğunun } \\ & \text { kırılması, aracımın lastiğinin patlaması, ilkellik, } \\ & \text { ailesi boşanmış çocuk, hobilerimden geri kalmak } \\ & \text { ve zaman kaybi, ölüm }(f=2) \text {, kapall alanda kalmak } \\ & (f=3)\end{array}$

Tedirginlik Diken üstünde durmak, can sıkıntısı, yolunu
(f=6) kaybetmek, korku filmi, karanlık korkusu $(f=2)$
K1: "Uykusuzluk. Çünkü uykuyu seviyorum." K41: “Korku filmi. Çünkü sorun
olmadı̆̆ını
gerilirim."

\begin{tabular}{|c|c|c|}
\hline $\begin{array}{l}\text { Yalnızlık } \\
(\mathbf{f}=\mathbf{1 0})\end{array}$ & $\begin{array}{l}\text { Tek başıma kalmak, soyutlanma, ölüm, yalnız } \\
\text { kalmak }(f=7)\end{array}$ & $\begin{array}{l}\text { K6: "Ölüm. Çünkü telefonsuz hayat } \\
\text { benim için çok anlamsiz." }\end{array}$ \\
\hline $\begin{array}{l}\text { Çaresizlik } \\
(\mathbf{f}=\mathbf{5})\end{array}$ & $\begin{array}{l}\text { Çölde susuz kalmak, çaresizlik korkusu, parasız } \\
\text { yolda kalmak, derse girmek, hapis }\end{array}$ & $\begin{array}{l}\text { K51: "Hapis. Çünkü telefon } \\
\text { olmadığında kendimi bir yere } \\
\text { hapsedilmiş hissederim." }\end{array}$ \\
\hline $\begin{array}{l}\text { Alışlabilir bir } \\
\text { durum }(\mathbf{f}=2)\end{array}$ & Çikolata, Hiçlik & $\begin{array}{l}\text { K44: "Çikolata. Çünkü, çikolata da } \\
\text { bir bağımlılık yapar fakat bırakmasl } \\
\text { hiçte zor değil." }\end{array}$ \\
\hline
\end{tabular}

Ortalamanın üstünde Nomofobi düzeyine sahip katılımcıların ürettiği Nomofobi metaforlarına yönelik gerekçeler incelenmiş ve bu gerekçeler üzerinden oluşturulan kategoriler Tablo 8 'de sunulmuştur. Bu hususta, Nomofobi kavramı eksiklik $(f=28)$, tedirginlik $(f=6)$, yalnızlık $(f=10)$, çaresizlik $(f=5)$ ve alışılabilir bir durum $(f=2)$ kategorileri altında toplanmıştır. Bu kategoriler incelendiğinde Nomofobi düzeyi yüksek olan katılımcıların Nomofobi’yi genel olarak bir eksiklik olarak algıladıkları söylenebilir. Bu durumda katılımcılara göre cep telefonsuz kalmanın bir eksiklik hissettiren bir durum olduğu söylenebilir. Öte yandan yalnızlık, tedirginlik ve çaresizlik kategorileri de göz önünde bulundurulduğunda Nomofobi’nin daha ziyade kişide huzursuzluk yaratan olumsuz bir kavram olarak algılandığı söylenebilir.

Tablo 9. Ortalamanın Altındaki Nomofobi Düzeyine Sahip Katılımcıların Ürettiği Nomofobi Metaforları

Kategori Metafor Örnek

$\begin{array}{ll}\begin{array}{l}\text { Eksiklik } \\ \text { (f=18) }\end{array} & \text { Kör kuyularda merdivensiz kalmak, mutluluğumun } \\ & \text { elimden alınması, kaplumbağa, kereviz yemeği, } \\ & \text { boşluk, elektriksiz kalmak, tatsız tuzsuz bir yemek, } \\ & \text { saatimin kolumda olmaması, Fenerbahçe, dağ } \\ & \text { başında kalmak, acıkmak, en sevdiği oyuncağı artık } \\ & \text { olmayan bir çocuk, pazar günü işe çağrılan işçi, } \\ & \text { komada olmak, yolda kalmak, tekerleksiz araba, } \\ & \text { silgi, çikolatası kalan kadın }\end{array}$

K2: "Kör kuyularda merdivensiz kalmak. Çünkü telefonsuz kalırsam gözlerim kan ă̆lar bedenim kara toprakla dolar."

Tedirginlik Kara delik, korku filmi, kayınpederle tanışmak, $(\mathbf{f}=\mathbf{1 0})$ sınava geç kalmak, kaygı, oksijen, sınavda silgisiz kalmak, para, sinek

K21: "Kaygl. Çünkü bir gün
boyunca aileme ulaşamadığım
zaman ya da ailem bana ulaşamadığı 
Yalnızlık (f=8) Issız kalmak, tek kalma korkusu, boş hayat, sessizlik, 1şıksız kalmak, yalnız kalmak $(f=3)$
K31: "Boş hayat. Çünkü günümüzde her türlü iletişim telefon üzerinden sağlaniyorken telefonsuz kalmak iletişimi herkesle koparmak, yalnız kalmak gibi gelir."

$\begin{array}{ll}\text { Çaresizlik } & \text { Oyunu trolleyen arkadaş, para, asansörde kalmak, } \\ (\mathbf{f = 5}) & \text { evlat acısı, boşlukta kalmak }\end{array}$
$(\mathbf{f}=5)$

evlat acısı, boşlukta kalmak
K8: "Oyunu trolleyen arkadas.

Çünkü her ne kadar uğraşırsam uğraşayım sarf ettiğim çaba boşa gidecektir, elimde bir şey kalmayacaktır sinir dışında."

\begin{tabular}{llll} 
Alışılabilir bir & Korku filmi, çok samimi olmadı̆̆ım arkadaşımı K33: “Çok samimi olmadığım \\
durum (f=11) & $\begin{array}{l}\text { kaybetme, sigara içmek, alkol alamama, kabak, arkadaşımı kaybetme. Çünkü o } \\
\text { otobüsü kaçırıp yürümek, içki içememe korkusu, olmadan da hayatıma devam } \\
\text { sinek, hiçlik }(f=3)\end{array}$ & $\begin{array}{l}\text { edebilirim üzülsem de.” } \\
\end{array}$ \\
\hline
\end{tabular}

Ortalamanın altında Nomofobi düzeyine sahip katılımcıların ürettiği Nomofobi metaforlarına yönelik gerekçeler incelenmiş ve bu gerekçeler üzerinden oluşturulan kategoriler Tablo 9'da sunulmuştur. Bu hususta, Nomofobi kavramı eksiklik $(f=18)$, tedirginlik $(f=10)$, yalnızlık $(f=8)$, çaresizlik $(f=5)$ ve alışılabilir bir durum $(f=11)$ kategorileri altında toplanmıştır. Bu kategoriler incelendiğinde Nomofobi düzeyi düşük olan katılımcıların Nomofobi'yi genel olarak eksiklik ve alışılabilir bir durum biçiminde algıladıkları söylenebilir. Öte yandan tedirginlik, yalnızlık ve çaresizlik kategorileri de göz önünde bulundurulduğunda Nomofobi'nin olumsuz bir kavram olarak algılandığı söylenebilir.

\section{Tartışma ve Sonuç}

Çalışmada ele alınan olgular ve öğretmen adaylarının bu olgular üzerindeki algıları bağlamındaki görüşleri düşünüldüğünde; öğretmen adaylarının, akıllı telefonlarına "arkadaş, organ, yemek, ihtiyaç, sevgili” gibi yaşam açısından hayati anlamlar yükledikleri görülmektedir. Çalışmada Nomofobi ile ilgili olarak elde edilen metaforların, bireyin hayatta kalabilmesi için en temel ihtiyaçları oluşturduğu düşünüldüğünde; Nomofobi ile ilgili oluşan bu durumun bireyin kendisinin hayatta kalmasını etkilemekte olan çok ciddi bir psikolojik değişken olduğu sonucuna varılabilir. Çünkü psikolojik ve sosyal açıdan düşünüldüğünde bireyin arkadaşından, sevgilisinden ve/veya bir organından yoksun kalma; aç kalma vb. durumlar ile karşı karşıya kalmak istemeyeceği söylenebilir. Özellikle de "yemek" ve "organ" gibi bireyin yaşamda en temel fiziksel ihtiyaçlarını karşılayabileceği parametrelerin yoksunluğu, nomofobinin gelişmesini etkileyebilecektir. Çalışmada nomofobi için "yalnız kalma, hiçlik", FoMO için "geri kalma, gereksinim” metaforları öne çıkmaktadır. Maslow’un ihtiyaçlar hiyerarşisinde ilk iki katmanda fiziksel ihtiyaçlar ve güvenlik olduğu bilinmektedir. Öyle ki; bireyin bu ihtiyaçları karşıladıktan sonra üst basamaklarda yer alan ait olma, sevgi, değer ve kendini gerçekleştirme basamaklarına doğru ilerlemesi beklenmektedir. Bu basamakları gerçekleştirirken bireylerin kendine güvenmesi, sevgi ve onay ihtiyacını dışarıya gerek kalmaksızın kendilerinin karşılaması önemlidir. Fakat elde edilen metaforlarda da görüldüğü gibi akıllı telefonunu arkadaş ve sevgili olarak gören bir birey, romantik ve sosyal ilişkilerde yalnızlık duygusu yaşadığında; bu yalnızlığını gidermek için arkadaşlarını takip etme ve/veya ödül alabilme (beğeni) amacıyla yoğun bir şekilde akıllı telefonunu ve sosyal ağ sitelerini kullanabilmekte; dolayısıyla bir bağımlılık sendromu yaşamakta ve bunun sonucu olarak da nomofobik davranış belirtilerini gösterebilmektedir. Kendine güveni olmayan, öz benlik saygısı gelişmeyen ve kendini bir "hiç" olarak gören bireylerin kimlik kazanma çabası akıllı telefona ve sanal dünyaya daha da bağımlı olması anlamına gelebilir. Bu açıdan çalışmanın bulguları değerlendirildiğinde asıl problemin içinde bulunduğumuz teknolojik çağdaki uyarıcılardan ziyade daha da derinden bireyin kendisinden yaşadığ ortamdan kaynaklandığı söylemek mümkündür. Elde edilen bulgular bireylerin içinde bulunduğu aile, okul ve 
toplumdaki yaşam döngüsünde, kendisini gerçekleştirmek için uygun ortamı ve eğitimi bulamayışları ile açıklanabilir. Çünkü bu durumun oluşmasında şüphesiz ki ebeveynlerin akıllı telefona olan bağımlılıkları ve sosyal ağ sitelerindeki gelişmeleri sürekli takip etmelerinin etkili olduğu düşünülmektedir. Ayrıca ebeveynlerin nomofobik davranış örüntüleri sergilemelerinin çocuklarının koşulsuz sevgiye ihtiyaç duymalarını, bağımlılıktan ziyade bağlılık gibi önemli duygu durumlarının oluşmasını ve çocukları ile kaliteli vakit geçirme gibi aktivitelerin yetersizliğini de beraberinde getireceği düşünülmektedir. Bireyin kendini gerçekleştirebilmesinde temel fiziksel ile güvenlik ihtiyaçlarını gidermiş olmasının yanı sıra pedagojk açıdan doğru eğitimi almış, eğitim düzeyi yüksek, ekonomik açıdan yeterli bir aile yapısına sahip olmasının faydalı olabileceği düşünülmektedir. Bireylerin kendi kararlarını alabilmesi ve onaya bağımlı olmayarak; sevme/sevilme ve kendini değerli görme ihtiyaçlarını karşılamalarında aileler ile birlikte eğitimcilere de büyük sorumluluklar düşmektedir. Buna göre, yapılan çalışmada elde edilen bulgular 1şığında öğretmen adaylarının akıllı telefon metaforları ile ortaya koydukları düşünceler ve bu temelde yaşanabilecek toplumsal sorunların Nomofobi ve FoMO olguları açısından ele alınmasının önemi ortaya koyulmaktadır. Öyle ki, söz konusu öğretmen adaylarının ortaya koydukları metaforlar ile gelecekte öğrencilerinin kendilerini gerçekleştirmelerine yeterince yardımcı olma noktasında yaşanılan kaygılar bu çalışmanın bulguları ile daha da derinleşmektedir. Bu açıdan ele alınan ve üç temel saç ayağı olan akıllı telefon, Nomofobi ve FoMO ile ilgili bulguların birlikte ve ayrı ayrı ele alınmasının ve her bir durum ile ilgili algılarının sebeplerinin belirlenmesinin gerekli olduğu düşünülmektedir.

\section{GATKS Kapsamında Mobil Telefona İlişkin Sonuçlar}

Katılımcılardan elde edilen verilere göre, Mobil telefon yani günümüzdeki versiyonu ile akıllı telefon kavramına yönelik üretilen metaforların oldukça farklılaştığı ve en çok tekrar eden metaforların arkadaş, organ, yemek yemek, ihtiyaç, sevgili olduğu görülmüştür. Bu metaforlardan en fazla tekrar edenlerden organ diğerlerine göre daha hayati önem taşımaktadır. Bir organını kaybetmek bir bireyi ölüme kadar götürebilir. Aynı şekilde iyi bir sosyal ve duygusal ilişki içinde olmak mental olarak hem bireyin psikolojisi hem de toplumun daha sağlıklı bireylerden oluşması açısından önemlidir. Ayrıca yemek yemek, bireyin hayati eylemlerinden biridir. Hayatını idame edebilmesi için bir bireyin beslenmesi gerekmektedir. Maslow'un hiyerarşisinin temelinde fizyolojik ihtiyaçların karşılanması yer almaktadır. Dünya'da yaklaşık 832 milyon insanın açlıkla mücadele ettiği düşünüldüğünde, akıllı telefonunun metaforik anlamda "yemek" olarak ifade edilmesinin; akıllı telefonsuz kalındığında ölmek gibi bir şey olarak algılanabildiği durumu dikkat çekicidir. Araştırmacıların, uzmanların, ebeveynlerin, okul yöneticilerinin, eğitimcilerin, ailelerin hatta devlet büyüklerinin bu durumun olası sonuçlarını düşünmesi gerekmektedir. Çalışmada öğretmen adaylarının akıllı telefon ile ilgili belirtmiş oldukları metaforik algılara dayalı olarak; akıllı telefon kullanımının bireylerin fiziksel (Çakır ve Oğuz, 2017), sosyal (Hamutoğlu vd., 2018) ve psikolojik açıdan (Çakır ve Oğuz, 2017; Demirci vd., 2014; Enez Darcin, Kose, Noyan, Nurmedov, Yılmaz ve Dilbaz, 2016) oldukça önemli sonuçlarının olabileceği düşünülmektedir. Sonuç olarak, elde edilen metaforlar göz önünde bulundurulduğunda mobil telefonun katılımcıların hayatlarından daha ziyade elzem bir araç olarak algılandığı söylenebilir. Günlük akıllı telefon kullanım süresine ilişkin metaforlar Şekil 1'de yer almaktadir. 


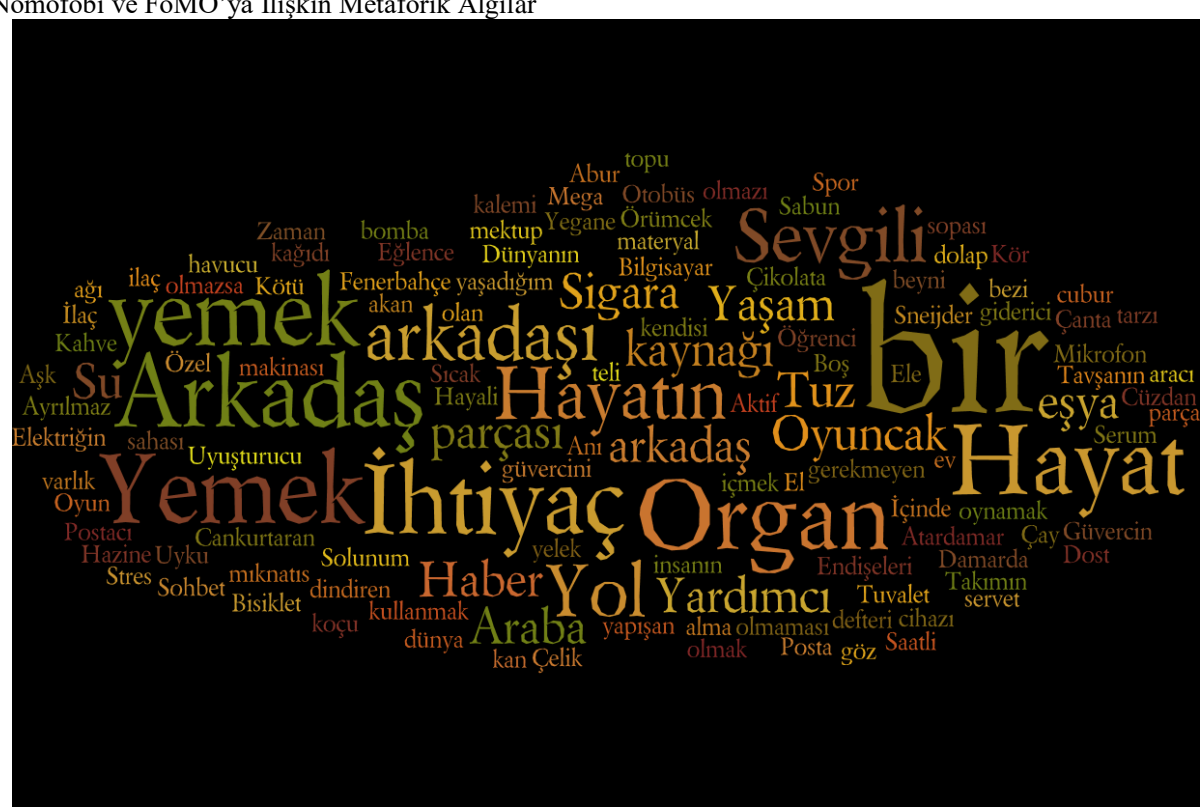

Şekil 1. Günlük Akıllı Telefon Kullanım Süresine İlişkin Metaforlar

\section{GATKS Kapsamında Ortalama Altı-Üstü Süreye Göre Mobil Telefona ilişkin Sonuçlar}

Katılımcıların günlük akıllı telefon kullanım süreleri dikkate alındığında ortalama sürenin üstündeki katılımcıların ürettikleri mobil telefon metaforları farklı ihtiyaçları gidermede kolaylaştırıcılık, bağımlılık-olmazsa olmazlık ve dostluk kategorileri altında toplanırken; ortalamanın altında kalanlarınki farklı ihtiyaçları gidermede kolaylaştırıcılık ve olmazsa olmazlık- bağımlılık gibi aynı kategorilerde kendini göstermiştir. Bu durumda elde edilen kategorilerin akıllı telefonu vazgeçilmez, kolaylaştırıcı ve dostane bir araç olarak ortaya koydukları söylenebilir. Öte yandan, hem ortalamanın üstünde hem de ortalamanın altında telefon kullananlar için mobil telefon farklı ihtiyaçları gidermede kolaylaştırıcılık ve bağımlılık-olmazsa olmazlık olarak algılanmaktadır. Ancak, ilgili kategoriler incelendiğinde, ortalamanın üstünde olan kişilerin mobil telefonu ağırlıklı olarak bağımlılıkolmazsa olmaz bir şey gibi algılarken; ortalamanın altında olan kişilerin mobil telefonu ağırlıklı olarak kolaylaştırıcılık şeklinde algıladıkları görülmektedir. Akıllı telefonlar bireylerin her yerde ve istediklerinde her şeye ulaşmalarını sağlayan bir teknolojik cihazdır. İçerisinde barındıkları uygulamalar ile öğrenciler akıllı telefonları ile epey zaman geçirmektedirler. Bu geçirilen zaman öğrencinin akıllı telefona karşı bağlanmasına sebep olan faktörlerden biri olduğu söylenebilir. Çünkü edinilen sonuçlara göre, akıllı telefonu günlük ortalamanın üstünde kullanan kişiler mobil telefona bağımlılığı artmaktadır. Bu cümleyi destekler şekilde Wu, Cheung, Ku ve Hung (2013) akıllı telefon bağımlılığı riski ile akıllı telefonda geçirilen zaman arasında bir anlamlı ilişki olduğunu tespit etmişlerdir. Noyan, Enez Darçın, Nurmedov, Yılmaz ve Dilbaz (2015) tarafindan yapılan akıllı telefon bağımlılığı ölçek çalışmasında, 367 üniversite öğrencisinin akıllı telefon bağımlılığı verileri ile akıllı telefon kullanma süreleri arasında pozitif anlamlı bir ilişki olduğu saptanmıştır. Demirci, Orhan, Demirdas, Akpinar ve Sert (2014), akıllı telefonu yoğun olarak 16 saatten fazla kullanan kullanıcıların, akılı telefonu en fazla 4 saat ve 4 saatten daha az kullananlara göre daha akıllı telefon bağımlılığı ölçek puanlarının daha yüksek olduğu elde etmektedir. Son olarak Dikeç ve Kebapçı (2018) 265 üniversite öğrencisi ile yaptığı çalışmada da günlük akıllı telefon kullanımı ile ortalama ölçek puanı arasında pozitif bir ilişki olduğunu ortaya koymaktadır. Bu nedenle, öğrencilerin mobil telefona karşı verdikleri metafor ve kategorilerin, akıllı telefon bağımlılığı alanyazını ile benzerlikler gösterdiği ve sonuç olarak akıllı telefonların gün içerisinde yoğun kullanımının bireylerin akıllı telefona bağımlılık seviyesini arttırdığı söylenebilir. Şekil 2 ve Şekil 3’te günlük akıllı telefon kullanım ortalama süresinin altı ve üstüne göre elde edilen metaforlar yer almaktadır. 


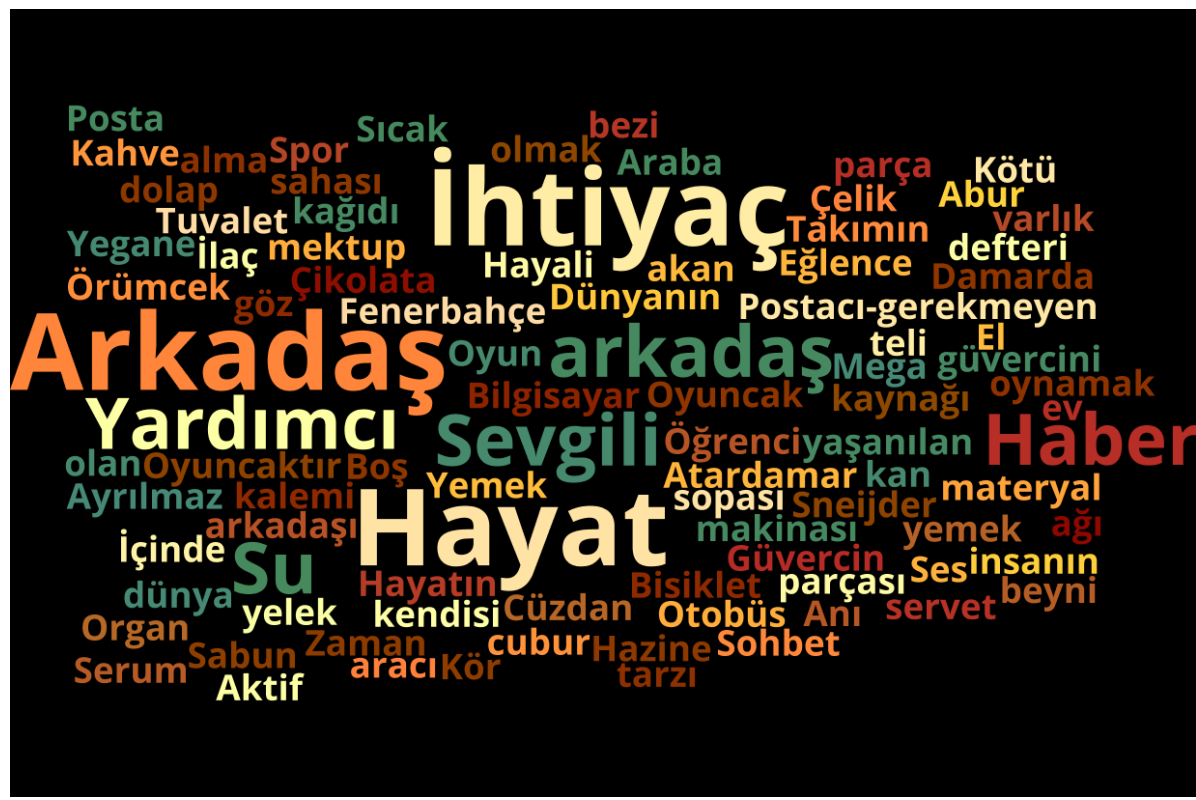

Şekil 2. Günlük Akıllı Telefon Kullanım Ortalama Süresi Altına İlişkin Metaforlar

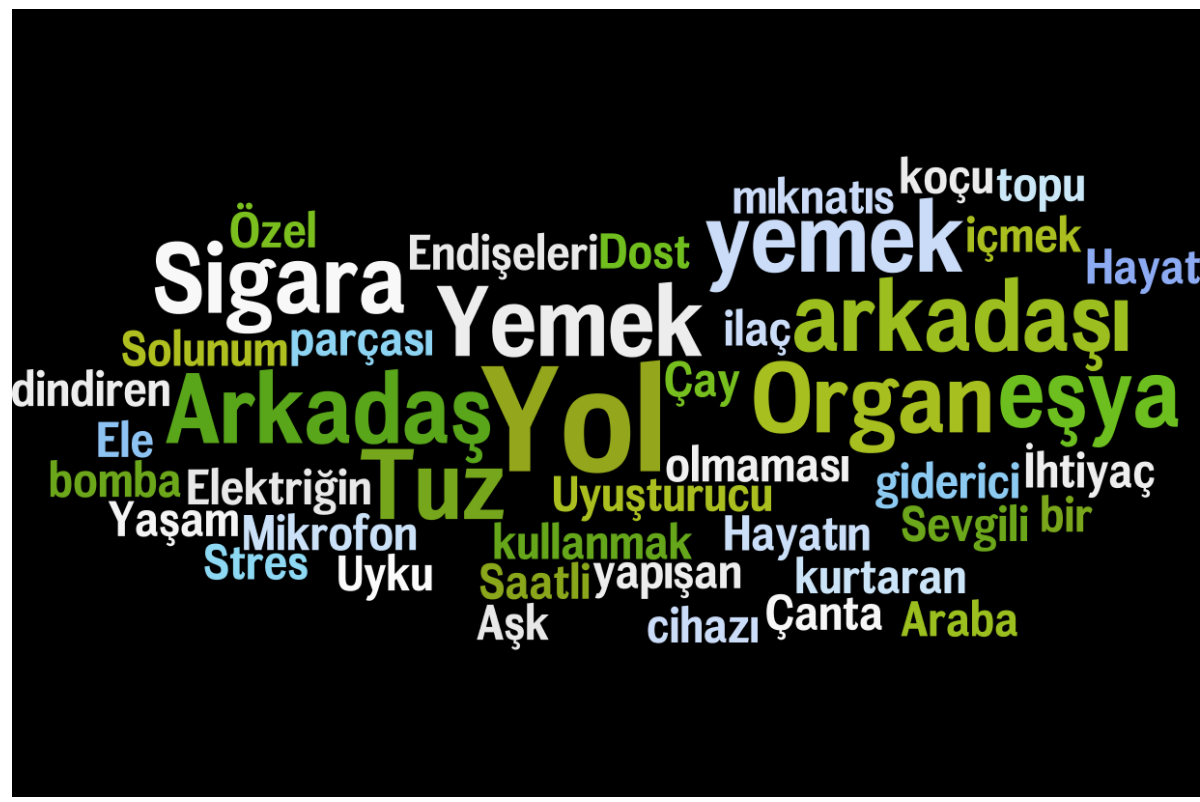

Şekil 3. Günlük Akıllı Telefon Kullanım Ortalama Süresi Üstüne İlişkin Metaforlar

FoMO Metaforlarına İliş̧in Sonuçlar

Katılımcılardan elde edilen verilere göre, FoMO kavramına yönelik üretilen metaforların oldukça farklılaştı̆̆ ve en çok tekrar eden metaforların "gündemden geri kalmak, cahil, bilgisiz kalmak, ıssız adaya düşmek, kötü bir olay” olduğu görülmüştür. Elde edilen metaforlar göz önünde bulundurulduğunda FoMO’nun daha ziyade olumsuz bir durum olarak algılandığı; bu sebeple de, katılımcıların çoğunun gelişmeleri kaçırma korkusuna sahip olduğu söylenebilir. FoMO'ya ilişkin metaforlar Şekil 4'te yer almaktadır. 


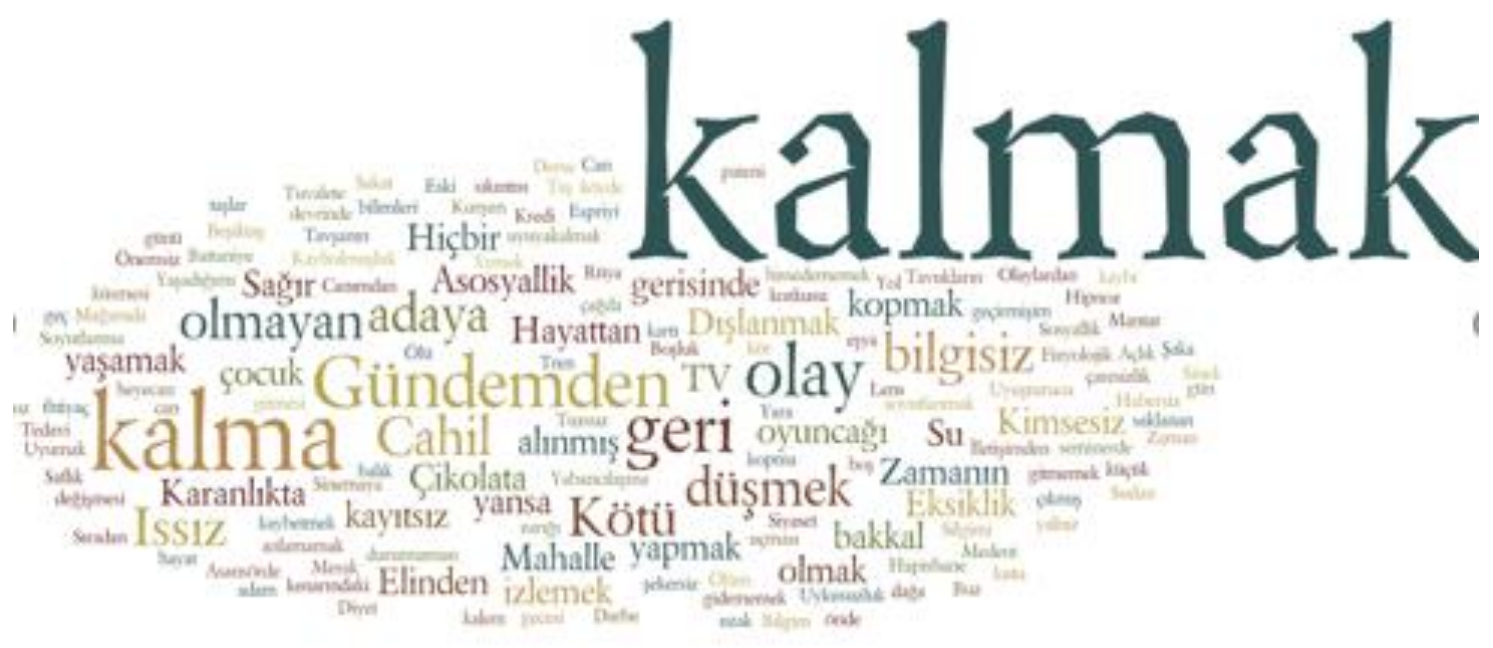

Şekil 4. FoMO’ya İlişkin Metaforlar

\section{FoMO Düzeyi Ortanın Altına-Üstüne İlişkin Sonuçlar}

Metaforlar incelendiğinde, FoMO düzeyi ortalamanın altında ve üstünde olan her iki katılımcı grubu için de FoMO öncelikle "bir şeylerden geri kalma" olarak algılanmaktadır. Öte yandan, ortalama üstü FoMO'ya sahip olan katılımcılar ikinci sırada FoMO'yu bir temel ihtiyaç üzerinden vazgeçilmez bir eylemden eksik kalma olarak değerlendirirken; ortalama altı FoMO'ya sahip olan katılımcılar ikinci sırada FoMO'yu alışılabilir bir durum üzerinden çok da önemsenmeyen, olmasa dahi hayatlarına devam edebilecekleri bir unsur olarak değerlendirmektedir. Erişilen bu sonucun FoMO kavramının doğası düşünüldüğünde kendi içerisinde tutarlılık gösterdiği söylenebilir. Çünkü FoMO kavramı anlamı itibariyle gelişmeleri kaçırma korkusuna tekabül etmektedir. $\mathrm{Bu}$ yüzden her iki grubun da (ortalama altı ve üstü) FoMO'yu ilk sırada bir şeylerden geri kalma olarak algılamalarının normal olduğu söylenebilir. Öte yandan FOMO düzeyi düşük olan kişiler doğal olarak gelişmeleri takip edememe kaygısını daha az yaşayacaklarından, FoMO'yu alışılabilir bir durum olarak görmelerinin beklenen bir durum olduğu söylenebilir. FoMO, sosyal medyanın kullanım artışı ile gündeme gelen bir bağımlılık türü olarak ortaya çıkmıştır. Sosyal medyanın özellikle sosyal ağ sitelerinin kullanımını arttıran önemli faktörlerden biri olarak kabul edilmektedir (Przybylski vd., 2013). Aynı zamanda akıllı telefon bağımlılığının yordayıcılarından biri olarak da görülen çalışmalar bulunmaktadır (Gezgin, 2018). 2004 yılından itibaren Facebook gibi sosyal ağ sitelerinin kullanılması ve beraberinde farklı özelliklerin eklenerek sürekli gelişmesi, farklı yönlere evirilmesi ile bireylerin sosyal ağ sitelerinde vakit geçirme süreleri de artmıştır. 2010 yılından bu yana hayatımızda olan, günümüzde üniversite öğrencileri arasında yaygınlıkla kullanılan Instagram gibi popüler sosyal medya uygulamaları da bireylerin günlük kullanım süresini arttırmada önemli rol oynamaktadır. 2012 yılında yapılan bir çalışmada, her 10 kişiden 8'inin sosyal medyayı kim olduklarını göstermek ve ne yaptıkları hakkında övünmek için kullandıkları düşüncesini ortaya koymuştur (Laird, 2012). FoMO düzeyi yüksek çıkan bireylerin genel memnuniyet düzeylerinin, genel ruh hallerinin, refah seviyelerinin ve yaşam memnuniyetlerinin düşük olduğu bilinmektedir (Przybylski vd., 2013). Bu çalışmada da öğretmen adaylarının FoMO düzeylerinin bağlı olduğu durumlar metaforlar aracıllğıyla belirlenmiş olup; elde edilen sonuçlar yüksek FoMO düzeyindeki bireylerin genel olarak bir eksiklik, yoksunluk yaşadığını göstermektedir. Çünkü ekonomik durumu zayıf olan öğrenciler, sosyal ağlarda lüks ve refah içinde yaşayanları -en azından öyle gösterenleri- takip edebilir. Aynı zamanda düşük ruh hali, öz güven ya da öz benlik saygısı düşük olan bireyler, normal hayatında alamadığı onayı, sosyal ağlarda daha çok paylaşımlar yaparak almak isteyebilir. Son olarak, yaşadığı coğrafya ve kültür yüzünden baskı gören bireylerin, sosyal ağlarda daha çok zaman geçirmesini sağlayabilir. Bu durumlar, FoMO'nun beslendiği ve sonucunda beslediği sosyal ağ kullanım artışı olarak dönebilir. Fakat tam tersi düşünüldüğünde, Sosyal ağların sunduğu neredeyse sınırsız bilgi ve bağlantı kaynakları, öğrencilerin çevrimiçi etkinlikler, bu etkinliklere kimlerin katılacağı ve arkadaşları tarafından kullanılan bilgiler hakkında haberdar olmalarını sağlayacaktır. Bu durum, öğrencilerin sosyal medyada ait olma ihtiyacını karşılamak yerine, bu ihtiyacını gözden kaçırıp daha çok 
anlamsızca sosyal ağ kullanımını arttırmakta, böylece FoMO ile sosyal medya kullanımı arasında karşılıklı bir kısır döngü ortaya çıkmaktadır (Oberst, Wegmann, Stodt, Brand ve Chamarro,2017). Bu durumun, öğrencilerin akademik hayatları açısından, formal yada informal kesilmelere, konsantrasyon bozukluklarına sebep olduğu belirtilmektedir (Alt, 2015). Başka bir bakışla, FoMO’nun bireyleri daha çok tüketim toplumu olmaya özendirmesi de olumsuz etkileri arasında söylenebilir (JWTIntelligence, 2012). Bu açıdan FoMO ile ilgili metaforlar öğrencilerin çoğunda FoMO’nun varlığını gözler önüne sermektedir. Şekil 5 ve Şekil 6'da FoMO düzeyinin ortalama altı ve üstüne göre elde edilen metaforlar yer almaktadır.

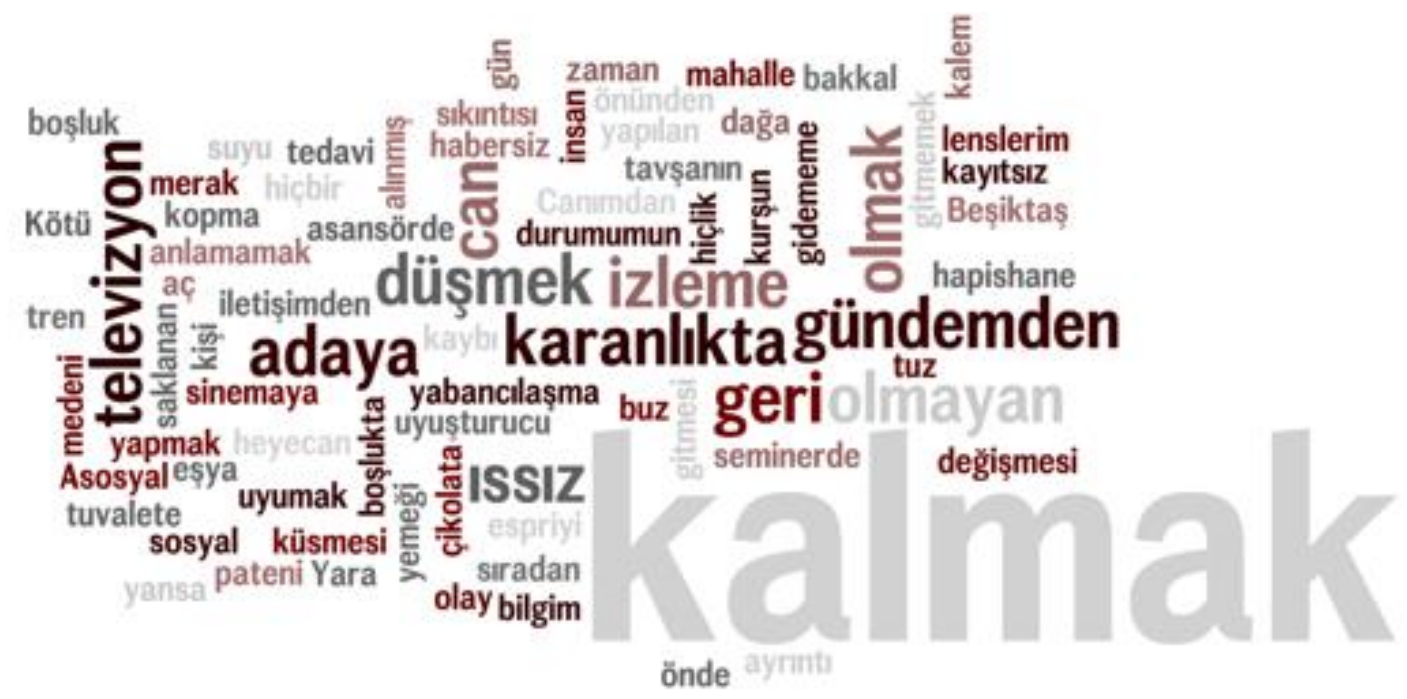

Şekil 4. FoMO Düzeyi Ortalama Altına İlişkin Metaforlar

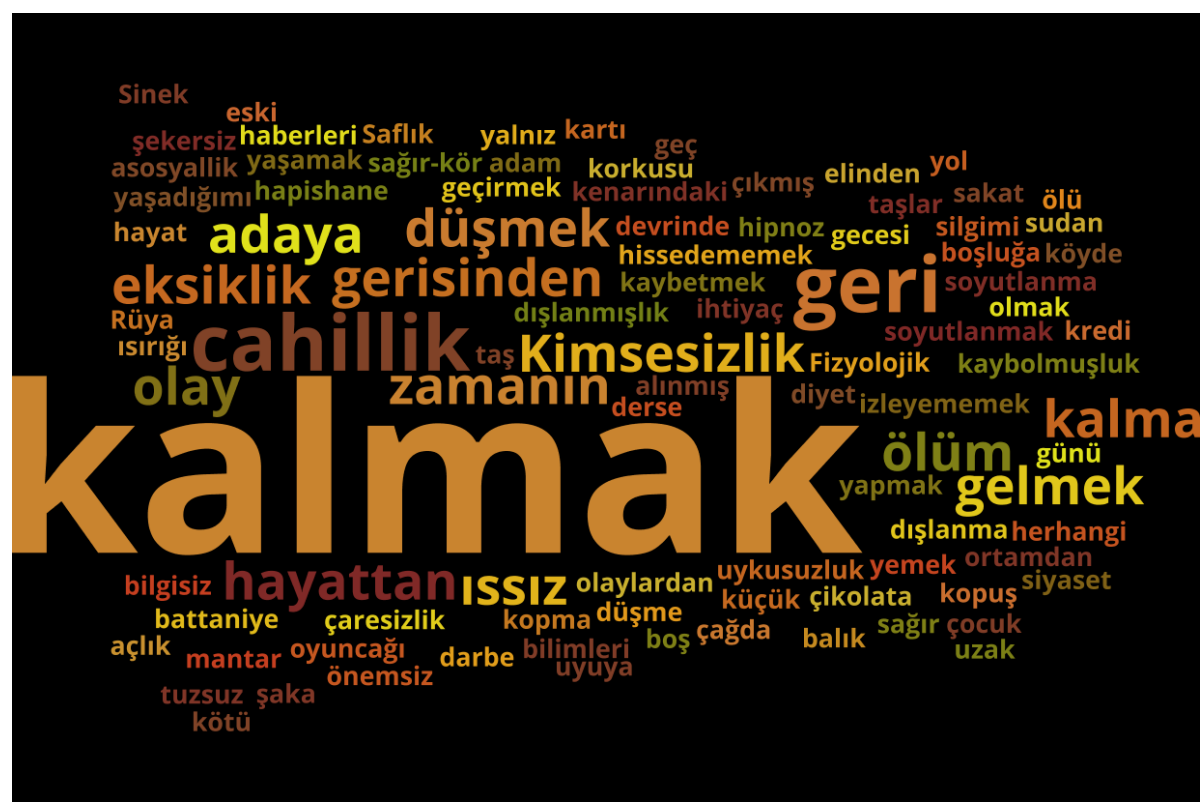

Şekil 5. FoMO Düzeyi Ortalama Üstüne İlişkin Metaforlar 
Nomofobi metaforları incelendiğinde elde edilen verilere göre, Nomofobi kavramına yönelik üretilen metaforların oldukça farklılaştığı ve en çok tekrar eden metaforların “yalnız kalmak ve hiçlik” olduğu görülmüştür. Elde edilen metaforlar göz önünde bulundurulduğunda Nomofobi'nin daha ziyade olumsuz bir durum olarak algılandığı; bu sebeple de, katılımcıların çoğunun cep telefonsuz kalma korkusuna sahip olduğu söylenebilir. Nomofobiye ilişkin metaforlar Şekil 6'da yer almaktadır.

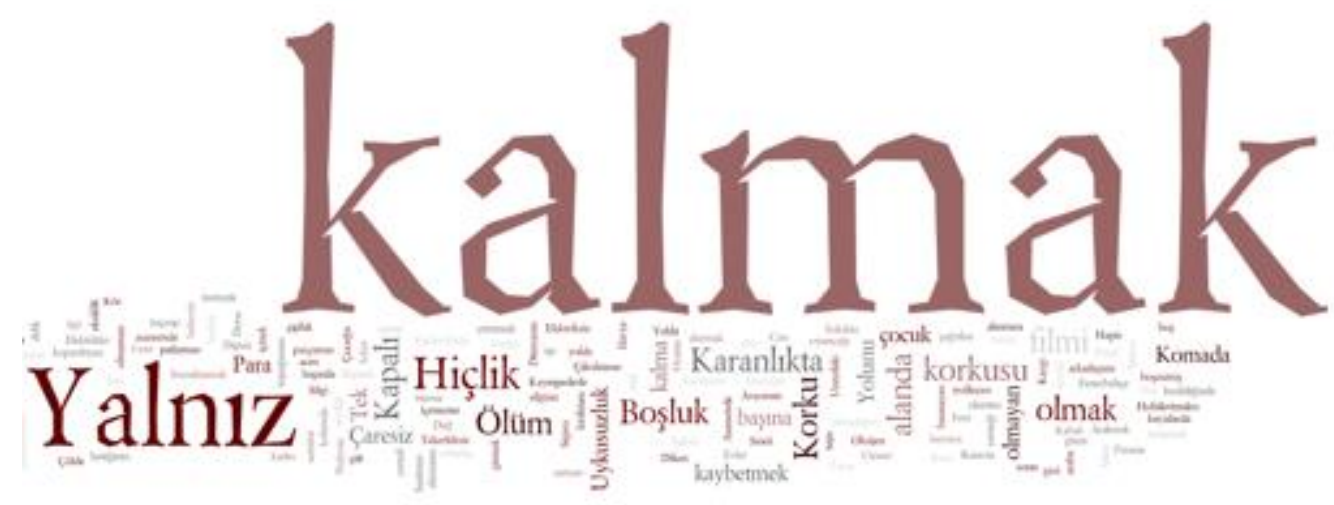

Şekil 6. Nomofobiye İlişkin Metaforlar

\section{Nomofobi Düzeyi Orta Altına-Üstüne İlişkin Sonuçlar}

Bu durumda Nomofobi düzeyi ortalamanın altında ve üstünde olan her iki katılımcı grubu için de Nomofobi öncelikle "eksiklik" olarak algılanmaktadır. Öte yandan, ortalama üstü Nomofobi’ye sahip olan katılımcılar ikinci sırada Nomofobi'yi bir yalnızlık olarak değerlendirirken; ortalama altı Nomofobi’ye sahip olan katılımcılar ikinci sırada Nomofobi'yi alışllabilir bir şey olarak görmektedir. Erişilen bu sonucun Nomofobi kavramının doğası düşünüldüğünde kendi içerisinde tutarlılık gösterdiği söylenebilir. Çünkü Nomofobi kavramı anlamı itibariyle cep telefonsuz kalma korkusunu ifade ettiği için her iki grubun da (ortalama altı ve üstü) Nomofobi’yi ilk sırada eksiklik olarak algılamalarının normal olduğu söylenebilir. Öte yandan Nomofobi düzeyi düşük olan kişiler doğal olarak cep telefonsuz kalma kaygısını daha düşük yaşayacaklarından dolayı Nomofobi'yi alış1labilir bir durum olarak görmelerinin beklenen bir durum olduğu söylenebilir. Nomofobi düzeyi yüksek olan bireylerin sıklıkla tekrarladığı metafor olan yalnızlık için alanyazında çalışmalar bulunmaktadır. King ve diğ. (2014) tarafından yapılan çalışmada panik atak rahatsızlığı olan hastalar arasında bir deney gerçekleştirilmiştir. Deney sonucunda, telefonsuz kalan deney grubu, kontrol grubu tarafindan hissedilen duygulara kıyasla, daha fazla yalnızlık, güvensizlik ve daha düşük benlik saygısı hissettiklerini bildirmişlerdir. Durak (2018b) tarafından 786 öğrenci tarafından yapılan çalışmada Nomofobi ile yalnızlık arasında orta düzeyde pozitif bir ilişki bulunmuştur. Ozdemir, Cakir ve Hussain (2018) tarafından yapılan Pakistan ve Türkiye'deki üniversiteliler arasındaki çalışmada yalnızlık ile tüm öğrenciler baz alındığında anlamlı pozitif bir ilişki olduğu saptanmıştır. Gezgin, Hamutoglu, Sezen-Gültekin ve Ayas tarafından (2018) ergenler üzerinde yapılan çalışma da diğer çalışmaları destekler şekilde Nomofobi ile yalnızlık arasında orta düzeyde bir ilişki olup, nomofobinin yordayıcılarından birinin yalnızlık olduğu ortaya konulmuştur. Yapılan çalışma ve alanyazındaki çalışmalar göstermektedir ki öğrencilerin akıllı telefonları yanlarında olmadıklarında ya da olsa bile bazen kendilerini yalnız hissetmektedir. Şekil 7 ve Şekil 8 'de Nomofobi düzeyinin ortalama altı ve üstüne göre elde edilen metaforlar yer almaktadır. 


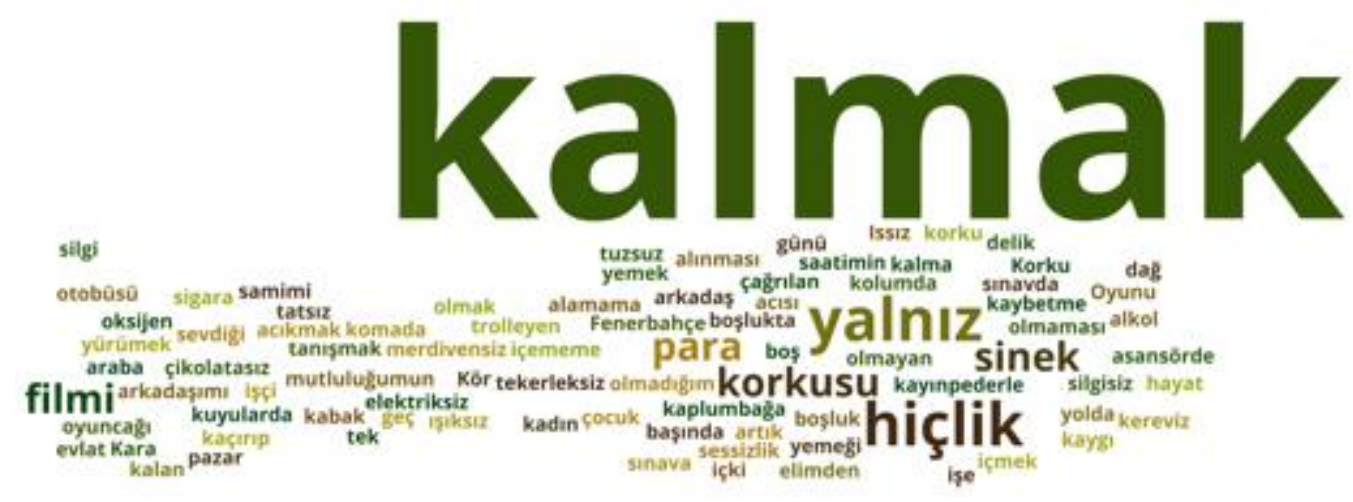

Şekil 7. Nomofobi Düzeyi Ortalama Altına İlişkin Metaforlar
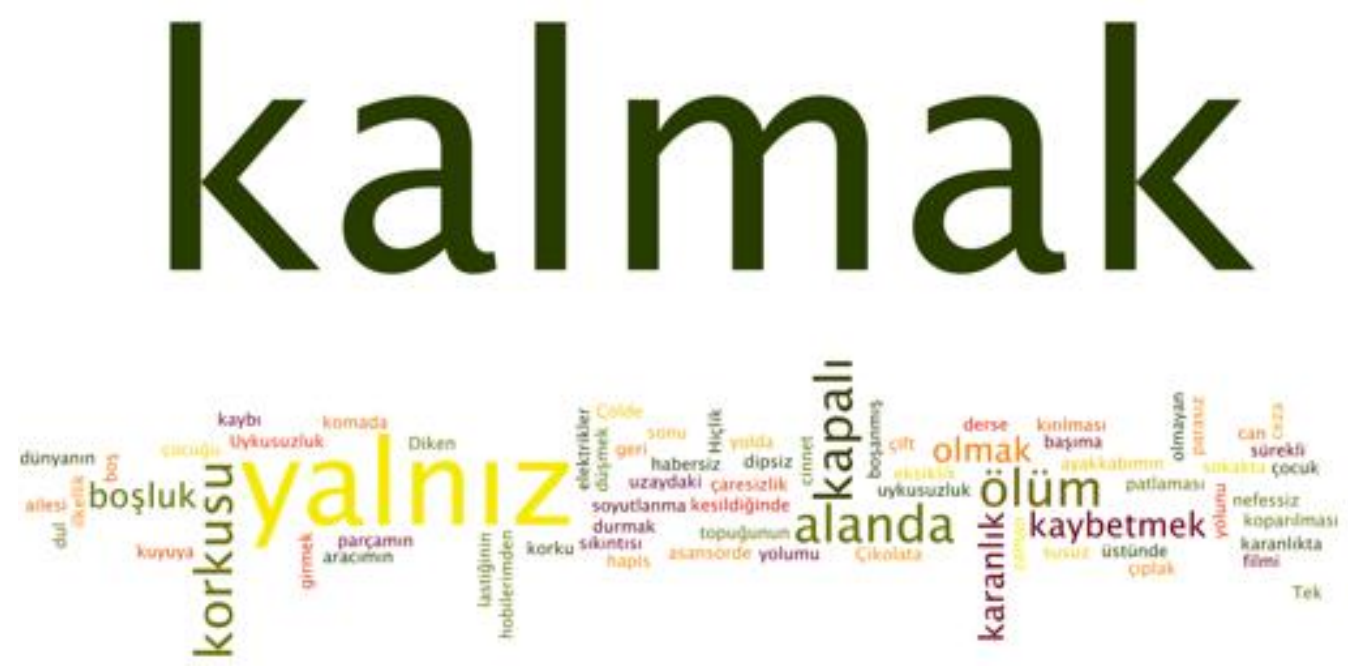

Şekil 8. Nomofobi Düzeyi Ortalama Üstüne İlişkin Metaforlar

\section{Öneriler}

Çalışmadan elde edilen sonuçlara göre varılabilecek çıkarımlar ve yapılan öneriler aşağıda sıralanmıştır.

- Akıllı telefon ile ilgili metaforlar incelendiğinde, öne çıan arkadaş, organ, yemek yemek, ihtiyaç, sevgili metaforları öğrenciler için akıllı telefonun neredeyse hayati fonksiyonlarının yerine konulabileceği düzeyde önemli olduğu görülmüştür. Akıllı telefonların öğretmen adaylarının hayatında adeta bir organ gibi elzem olduğu söylenebilir.

- Akıllı telefonda zaman geçirme süresi metaforları incelendiğinde, olmazsa olmazlık- bağımlıllk kategorisinin ön plan çıktığı görülmüştür. Akıllı telefon ile geçirilen sürenin artması akıllı telefon bağımlılık riskini arttırmaktadır. Yapılan çalışmalar akıllı telefonların çoğunlukla sosyal ağlar, oyun ve eğlence için kullanıldığını göstermektedir. İleride yapılacak çalışmalar ile bu yoğun kullanımın içinde mobil öğrenme ve ödev, araştırma amaçlı kullanımların hangi seviyede olduğu, bu kullanım düzeyinin düşük olması durumunda neden bu eylemlerin yapılmadığı nitel çalışmalarla sorgulanabilir. Aynı zamanda öğrencilerin karakter özelliklerine göre akıllı telefon kullanma süreleri ve uygulamaları tespit edilirse, her öğrenci grubuna göre bir öğrenme faaliyeti gerçekleştirilmesi için tasarımlar yapılabilir. 
- FoMO metaforları incelendiğinde, FoMO’nun doğası gereği “bir şeylerden geri kalma” olarak geri kalma olarak öne çıktığı görülmüştür. Öğretmen adaylarının, gelişmeleri kaçırma konusunda kaygıları olduğu söylenebilir. Gerek Sosyal ağlardaki güncellemeler, gerekse yaşadığımız coğrafya ve dünyada yaşanılan ekonomik, siyasi, toplumsal ve magazinsel durumların elde edilen bu sonuç üzerinde etkili olduğu düşünülebilir. Bu açıdan üniversite öğrencilerinin istedikleri hayatları yaşayamamaları ve bunun için Sosyal ağlarda var olmak istemeleri akla gelebilir İleride yapılacak çalışmalarda, Akıllı telefon süresi, Sosyal ağ kullanım süresi, kullanılan sosyal ağlar ve FoMO arasındaki ilişkinin tespit edilmesi ile hangi uygulama ve özelliklerinin akıllı telefonlarda uzun süreler geçirmeye neden olduğu bulunabilir. $\mathrm{Bu}$ özellikler ortaya çıkarıldığında, eğitim-öğretim faaliyetlerinde tasarlanacak uygulamalar ve materyallerde elde edilen bulgulardan yararlanılabilir. Ayrıca, elde edilecek sonuçların eğitim-öğretim faaliyetlerinde sosyal ağ sitelerinden faydalanma konusunda akademisyen ve öğretmenlere yarar sağlayacağı düşünülmektedir.

- Nomofobi metaforları incelendiğinde, "yalnızlık” metaforunun öne çıktığg görülmektedir. Öğretmen adaylarının yalnızlıklarının artması nomofobinin artmasına neden olmaktadır. Ayrıca akıllı telefon metaforundaki "sevgili ve arkadaş" metaforları da bu sonuca destek vermektedir. İleride yapılacak çalışmalarla yalnızlığın boyutu ve çeşidi (Duygusal, Sosyal ve Ailevi) ortaya konulabilir. Ayrıca, nitel çalışma ile üniversite öğrencilerinin yalnızlık sendromu yaşamaları altında yatan sebepler araştırılabilir. Bu çalışmalardan elde edilecek sonuçlar, Nomofobi üzerinde yapılan çalışmalarına yön verecektir. Unutulmamalıdır ki, mental ve fiziksel açıdan sağlıklı toplumlar, refah seviyesinin artmasını, bu sayede de mutluluğun artmasını sağlayacaktır.

\section{References}

Ak, N. Y., \& Yildirim, S. (2018). Nomophobia among undergraduate students and its link to mobile learning. Education, 81, 55-48.

Akıllı, G. K., \& Gezgin, D. M. (2016). Üniversite öğrencilerinin nomofobi düzeyleri ile farklı davranış örüntülerinin arasındaki ilişkilerin incelenmesi. [Examination of the Relationship Between Nomophobia Levels and Different Behavior Patterns of University Students]. Mehmet Akif Ersoy Üniversitesi Eğitim Fakültesi Dergisi/ Mehmet Akif Ersoy University Journal of Education Faculty, 1(40), 51-69.

Akturan, U., \& Esen, A. (2008). Fenomenoloji (ss.83-98), Nitel araştırma yöntemleri, (Ed.T. Baş ve U. Akturan). [Scientific research methods)] Ankara: Seçkin Publishing.

Alfawareh, H. M., \& Jusoh, S. (2014). Smartphones usage among university students: najran university case, International Journal of Academic Research, 6(2), 321-326.

Alt, D. (2015). College students' academic motivation, media engagement and fear of missing out. Computers in Human Behavior, 49, 111-119, http://dx.doi.org/10.1016/j.chb.2015.02.057.

Annells, M. (2006). Triangulation of qualitative approaches: Hermeneutical phenomenology and grounded theory. Journal of Advanced Nursing, 56(1), 55-61.

Beyens, I., Frison, E., \& Eggermont, S. (2016). I don't want to miss a thing: Adolescents' fear of missing out and its Relationship to adolescents' social needs, Facebook use, and Facebook related stress. Computers in Human Behavior, 64, 1-8.

Burucuoğlu, M. (2017). Meslek yüksekokulu öğrencilerinin nomofobi düzeyleri üzerinde bir araştırma.[ A research on nomophobia levels of vocational college students]. Karabük Üniversitesi Sosyal Bilimler Enstitüsü Dergisi/ Karabuk University University Journal of the Institute of Social Sciences, 7(2), 482-489. 
Casey, B. M. (2012). Linking psychological attributes to smart phone addiction, face-to-face communication, present absence and social capital. Graduation Project, Graduate School of the Chinese University of Hong Kong.

Creswell, J. W. (2003). Research design: Qualitative, quantitative, and mixed methods approaches (2nd ed.). Thousand Oaks, CA: Sage.

Creswell, J. W. (2013). Qualitative inquiry \& research design: Choosing among five approaches (4th ed.). New York: Sage.

Çakır, Ö., \& Oğuz, E. (2017). Lise Öğrencilerinin Yalnızlık Düzeyleri ile Akıllı Telefon Bağımlılığı Arasındaki İlişki. [The Correlation between High School Students' Loneliness Levels and Smart Phone Addiction] Mersin University Journal of the Faculty of Education, 31(1).

Dağlı, E., Hamutoğlu, N. B. ve Gezgin, D. M. (2017). Okul Öncesi Öğretmenlerinin Nomofobi Düzeyleri ile Akıllı Telefon ve Sosyal Ăg Servisleri Kullanma Davranışları Arasındaki İlişkinin İncelenmesi. [The Investigation of the Relationship Between the Nomofobi Levels of Pre-School Teachers and Using Behaviors of Smart Phone and Social Network Services].Uluslararası Bilgisayar ve Öğretim Teknolojileri Sempozyumu/International Computer \& Intructional Technologies Symposium, ICITS-2017, 24-26 Mayıs, Malatya.

Dağlı, E., Gezgin, D. M., Hamutoğlu, N. B. ve Sezen-Gültekin, G. (2017). Okul Öncesi Öğretmenlerinin Mobil Telefon Yoksunluğu (Nomofobi) Düzeylerinin Farklı Değişkenler Açısından İncelenmesi. [Examining the Levels of Mobile Phone Deprivation (Nomophobia) Levels of Preschool Teachers in Terms of Different Variables]. VII. Uluslararası Eğitimde Araştırmalar Kongresil International Congress of Research in Education, 27-29 Nisan, Çanakkale.

Demirci, K., Akgönül, M., \& Akpinar, A. (2015). Relationship of smartphone use severity with sleep quality, depression, and anxiety in university students. Journal of Behavioral Addictions,4(2), 85-92.

Demirci K., Orhan, H., Demirdas, A., Akpinar., A., \& Sert, H. (2014). Validity and reliability of the Turkish Version of the Smartphone Addiction Scale in a younger population. Klinik Psikofarmakoloji Bülteni-Bulletin of Clinical Psychopharmacology, 24, 226-34.

Dikeç, G., \& Kebapçı, A. (2018). Smartphone Addiction Level among a Group of University Students. Journal of Dependence, 19(1), 1-9.

Durak, H. Y. (2018a). Investigation of nomophobia and smartphone addiction predictors among adolescents in Turkey: Demographic variables and academic performance. The Social Science Journal, https://doi.org/10.1016/j.soscij.2018.09.003.

Durak, H. Y. (2018b). What Would You Do Without Your Smartphone? Adolescents' Social Media Usage, Locus of Control, and Loneliness as a Predictor of Nomophobia. Addicta: The Turkish Journal on Addictions, 5(2), 1-15.

Enez Darcin, A., Kose, S., Noyan, C. O., Nurmedov, S., Y1lmaz, O., \& Dilbaz, N. (2016). Smartphone addiction and its relationship with social anxiety and loneliness. Behaviour \& Information Technology, 35(7), 520-525.

Erdem, H., Kalkin, G., Turen, U., \& Deniz, M. (2016). The Effects of No Mobile Phone Phobia (nomophobia) on Academic Performance among Undergraduate Students. The Journal of Faculty of Economics and Administrative Sciences,21(3), 923-936.

Fraenkel, J. R., Wallen, N. E., \& Hyun, H. H. (2012). How to Design and Evaluate Research in Education (8th edt.). New York: McGram-Hill Companies. 
Akıllı Telefon, Nomofobi ve FoMO’ya İlişkin Metaforik Algılar

Fuster, H., Chamarro, A., \& Oberst, U. (2017). Fear of Missing Out, online social networking and mobile phone addiction: A latent profile approach. Aloma: Revista de Psicologia, Ciències de l'Educació i de l'Esport, 35(1).

Gezgin, D. M. (2017). Exploring the Influence of the Patterns of mobile Internet use on University students'nomophobia levels. European Journal of Education Studies, https://doi/10.5281/zenodo.572344.

Gezgin, D. M. (2018). Understanding Patterns for Smartphone Addiction: Age, Sleep Duration, Social Network Use and Fear of Missing Out. Cypriot Journal of Educational Sciences, 13(2), 409-421.

Gezgin, D. M., Çakır, O., \& Yildirim, S. (2018). The Relationship between Levels of Nomophobia Prevalence and Internet Addiction among High School Students: The Factors Influencing Nomophobia. International Journal of Research in Education and Science, 4(1), 215-225.

Gezgin, D. M., Şumuer, E., Arslan, O., \& Yıldırım, S. (2017). Nomophobia prevalence among pre-service teachers: A case of Trakya University. Trakya Üniversitesi Eğitim Fakültesi Dergisi/Trakya University Faculty of Education Journal, 7(1), 86-95.

Gezgin, D. M., \& Çakır, Ö. (2016). Analysis of nomofobic behaviors of adolescents regarding various factors. Journal of Human Sciences, 13(2), 2504-2519.

Gezgin, D. M., Hamutoglu, N. B., Gemikonakli, O., \& Raman, I. (2017). Social networks users: fear of missing out in preservice teachers. Journal of Education and Practice, 8(17), 156-168.

Gezgin, D. M., Hamutoglu, N. B., Sezen-Gultekin, G., \& Ayas, T. (2018). The Relationship between Nomophobia and Loneliness among Turkish Adolescents. International Journal of Research in Education and Science, 4(2), $358-374$

Gezgin, D. M., Şahin, Y. L., \& Yıldırım, S. (2017). Sosyal Ağ Kullanıcıları Arasında Nomofobi Yaygınlığının Çeşitli Faktörler Açısından İncelenmesi. [The investigation of social network users' nomophobia levels regarding to various factors]. Eğitim Teknolojisi Kuram ve Uygulama/Educational Technology Theory and Practice, 7(1),1-15.

Gökçek, T. (2015). Kuramdan Uygulamaya Ĕ̆itimde Bilimsel Araştırma Yöntemleri (Ed. Metin, M.): Karma Yöntem Araştırması. (2. baskl). [Scientific Research Methods in Education from Theory to Practice:Mix Method Research (2nd Edition) ]Ankara: Pegem Akademi.

Gökler, M. E., Aydın, R., Ünal, E., \& Metintaş, S. (2016). Sosyal Ortamlarda Gelişmeleri Kaçırma Korkusu Ölçeğinin Türkçe sürümünün geçerlilik ve güvenilirliğinin değerlendirilmesi. [Determining validity and reliability of Turkish version of Fear of Missing out Scale]. Anatolian Journal of Psychiatry/Anadolu Psikiyatri Dergisi, 17 (Ek. 1), 52-59.

Hamutoğlu, N. B., Gezgin, D. M., Samur, Y., \& Yıldırım, S.(2018). Genç Nesil Arasında Yaygınlaşan Bir Bağımlılık: Akıllı Telefon Bağımlılı̆̆ının Farklı Değişkenler Açısından İncelenmesi. [A spreading addiction amongyoung generation: An examination of smartphone addiction according to gender, academic success and mobilegame playing variables]. Eğitim Teknolojisi Kuram ve Uygulama/ Educational Technology Theory and Practice, 8(2), 212-231.

Hayran, C., Anik, L., \& Gurhan-Canli, Z. (2016). Exploring the Antecedents and Consumer Behavioral Consequences of. ACR North American Advances, 44, 468-468.

Hawi, N. S., \& Samaha, M. (2016). To excel or not to excel: Strong evidence on the adverse effect of smartphone addiction on academic performance. Computers \& Education, 98, 81-89.

Hoşgör, H., Tütüncü, Ö. G. S. K., Hoşgör, Ö. G. D. G., \& Tandoğan, Ö. G. Ö. (2017). Üniversite öğrencileri arasında sosyal medyadaki gelişmeleri kaçırma korkusu yaygınlığının farklı değişkenler açısından incelenmesi. 
[Examination In Terms of Different Variables of Prevalence of Fear of Missing Out Among College Students]. International Journal of Academic Value Studies (Javstudies),3(17), 213-223.

Hughes, N., \& Burke, J. (2018). Sleeping with the frenemy: How restricting 'bedroom use'of smartphones impacts happiness and wellbeing. Computers in Human Behavior, 85, 236-244.

Karasar, N. (2009). Bilimsel Araştırma Yöntemi. (20. baskı). [Scientific Research Methods (20th edition)] Ankara: Nobel Publishing.

King, A. L. S., Valença, A. M., Silva, A. C., Sancassiani, F., Machado, S., \& Nardi, A. E. (2014). Nomophobia: Impact of Cell Phone Use Interfering with Symptoms and Emotions of Individuals with Panic Disorder Compared with A Control Group. Clinical Practice \& Epidemiology in Mental Health, 10, 28-35.

Laird, S. (2012, June 24th). Mashable. from Do You Suffer From Social Media FOMO?: http://mashable.com/2012/06/22/fomo-infographic/ sitesinden 20 Ocak 2018 tarihinde erişilmiştir.

Lemola, S., Perkinson-Gloor, N., Brand, S., Dewald-Kaufmann, J. F., \& Grob, A. (2015). Adolescents' electronic media use at night, sleep disturbance, and depressive symptoms in the smartphone age. Journal of youth and adolescence, 44(2), 405-418.

Miles, M. B., \& Huberman, M. A. (1994). Qualitative data analysis. Beverly Hills, CA: Sage

Noyan, C. O., Enez Darçın, A., Nurmedov, S., Yılmaz, O., \& Dilbaz, N. (2015). Akı1lı Telefon Bağımlılığı Ölçeğinin Kısa Formunun üniversite öğrencilerinde Türkçe geçerlilik ve güvenilirlik çalışması. [Validity and reliability of the Turkish version of the Smartphone Addiction Scale-Short Version among university students]. Anatolian Journal of Psychiatry/Anadolu Psikiyatri Dergisi, 16(Özel say1 1), 73-81.

Oberst, U., Wegmann, E., Stodt, B., Brand, M., \& Chamarro, A. (2017). Negative consequences from heavy social networking in adolescents: The mediating role of fear of missing out. Journal of adolescence, 55, 51-60.

Ozdemir, B., Cakir, O., \& Hussain, I. (2018). Prevalence of Nomophobia among University Students: A Comparative Study of Pakistani and Turkish Undergraduate Students. Eurasia Journal of Mathematics, Science and Technology Education, 14(4), 1519-1532.

Przybylski, A. K., Murayama, K., \& DeHaan, C. R. (2013). Motivational, emotional, and behavioral correlates of Fear of Missing Out. Comput Human Behav 29(4), 1841-1848.

Samaha, M., \& Hawi, N. S. (2016). Relationships among smartphone addiction, stress, academic performance, and satisfaction with life. Computers in Human Behavior, 57, 321-325.

Sırakaya, M. (2018). Ön Lisans Öğrencilerinin Nomofobi Düzeylerinin Akıllı Telefon Kullanım Durumlarına Göre İncelenmesi. [Examination of Associate Students' Nomophobia Levels According to Smart Phone Use]. Mersin University Journal of the Faculty of Education, 14(2).

JWTIntelligence. (2012, March). Fear of missing out (FOMO). JWT: http://www.jwtintelligence.com/wpcontent/uploads/2012/03/F_JWT_FOMO-update_3.21.12.pdf sitesinden 21 Ekim 2018 tarihinde erişilmiştir.

Tavşanc1l, E. \& Aslan, E. (2001). İçerik analizi ve uygulama örnekleri. [Content analysis and application examples] Istanbul: Epsilon Publishing.

Uysal, Ş., Özen, H., \& Madenoğlu, C. (2016). Social phobia in Higher Education: the influence of nomophobia on social phobia. The Global e-learning Journal, 5(2), 1-8.

Vanden Abeele, M., \& Van Rooij, T. (2016). Fear of missing out (FOMO) as a predictor of problematic social media use among teenagers. Proceedings of International Conference on Behavioral Addictions, ICBA'16. 
Akıllı Telefon, Nomofobi ve FoMO’ya İlişkin Metaforik Algılar

Yildirim, C., \& Correia, A. P. (2015). Exploring the dimensions of nomophobia: Development and validation of a self-reported questionnaire. Computers in Human Behavior, 49, 130-137.

Yıldırım, C., Sumuer, E., Adnan, M., \& Yıldırım, S. (2016). A growing fear: Prevalence of nomophobia among Turkish college students. Information Development, 32(5), 1322-1331.

Yıldırım, A., \& Şimşek, H. (2011). Sosyal bilimlerde nitel araştırma yöntemleri. [Qualitative research methods in the social sciences]. Ankara: Seçkin Publishing.

Wu, A. M., Cheung, V. I., Ku, L., \& Hung, E. P. (2013). Psychological risk factors of addiction to social networking sites among Chinese smartphone users. Journal of behavioral addictions,2(3), 160-166. 